University of Louisville

ThinkIR: The University of Louisville's Institutional Repository

Electronic Theses and Dissertations

$12-2010$

\title{
School-based decision making (SBDM) councils and their efficacy and productivity as perceived by council members.
}

Shawna Shrout Stenton 1976-

University of Louisville

Follow this and additional works at: https://ir.library.louisville.edu/etd

\section{Recommended Citation}

Stenton, Shawna Shrout 1976-, "School-based decision making (SBDM) councils and their efficacy and productivity as perceived by council members." (2010). Electronic Theses and Dissertations. Paper 1381. https://doi.org/10.18297/etd/1381

This Doctoral Dissertation is brought to you for free and open access by ThinkIR: The University of Louisville's Institutional Repository. It has been accepted for inclusion in Electronic Theses and Dissertations by an authorized administrator of ThinkIR: The University of Louisville's Institutional Repository. This title appears here courtesy of the author, who has retained all other copyrights. For more information, please contact thinkir@louisville.edu. 
SCHOOL-BASED DECISION MAKING (SBDM) COUNCILS AND THEIR EFFICACY AND PRODUCTIVITY AS PERCEIVED BY COUNCIL MEMBERS

By

\author{
Shawna Shrout Stenton \\ B.A., Hanover College, 1998 \\ M.A.T., Bellarmine University, 2000
}

\author{
A Dissertation \\ Submitted to the Faculty of the \\ Graduate School of the University of Louisville \\ In Partial Fulfillment of the Requirements \\ For the Degree of \\ Doctor of Philosophy \\ College of Education and Human Development \\ University of Louisville \\ Louisville, KY
}

December 2010 
Copyright (C) 2010 by Shawna Shrout Stenton

All rights reserved 



\title{
SCHOOL-BASED DECISION MAKING (SBDM) COUNCILS AND THEIR EFFICACY AND PRODUCTIVITY AS PERCEIVED BY COUNCIL MEMBERS
}

\author{
By
}

\author{
Shawna Shrout Stenton \\ B.A., Hanover College, 1998 \\ M.A.T., Bellarmine University, 2000
}

A Dissertation Approved on

September 30, 2010

By the following Dissertation Committee:

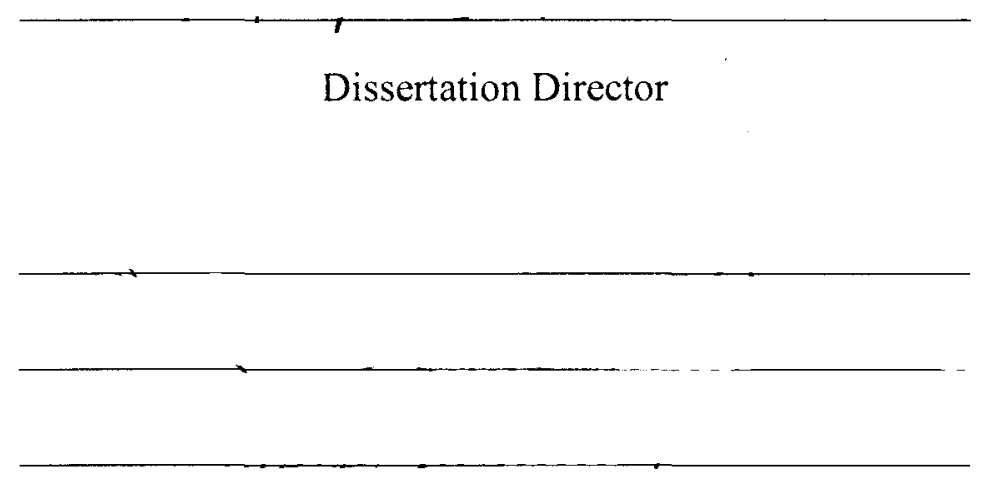




\section{DEDICATION}

This dissertation is dedicated to my husband, Thomas, and son, Michael, for all of the sacrifices they made so that this is even possible.

I would also like to dedicate this to my parents, Sharon and Rod Shrout, who instilled in me a love and appreciation for education and life-long learning. 


\section{ACKNOWLEDGEMENTS}

I would like to thank my dissertation committee, Dr. Joseph Petrosko, Dr. Marco Munoz, Dr. Carol Bartlett, Dr. Phyllis Connelly and the late Dr. Thaddeus Dumas, for their expertise and guidance. Their willingness to share time, knowledge, and advice made this dissertation possible.

I would also like to thank Susan Egan, Tamika Mozee, Rosalind Scott, and Sheila Stanton for sharing their technical expertise.

I would like to express my appreciation to the gentlemen of the Scottish Rite and the ladies of Women in Administration for their generous contributions to my education. 


\begin{abstract}
SCHOOL-BASED DECISION MAKING (SBDM) COUNCILS AND THEIR EFFICACY AND PRODUCTIVITY AS PERCEIVED BY COUNCIL MEMBERS
\end{abstract}

\title{
Shawna Shrout Stenton
}

September 30, 2010

This study examined the perceptions of Kentucky SBDM council members concerning the productivity and efficacy of the councils. The major variables studied were council member position, council member demographic characteristics, perceived efficacy, and perceived productivity.

The research data came from an already completed field survey. This study used the methods of descriptive analysis, causal-comparative analysis, and correlational/predictive research. Statistical procedures included calculation of means and standard deviations, as well as multivariate analysis of variance (MANOVA), ordinary least squares multiple regression, and random effects analysis of variance (ANOVA).

The results of the study showed that, in general, council members had a positive perception of the productivity and efficacy of the councils. There were no differences between the perceptions of parents and principals, nor between principals and teachers/staff. There was, however, a difference between parents and teachers/staff in 
regards to efficacy, with parents revealing a higher rating than teachers. Although the difference was statistically significant, it was small in magnitude.

Additional research explored the amount of variance in efficacy and productivity in relation to several predictor variables. The amount of variance in the average efficacy score could be predicted by the contrast between parents and principals/staff, relevant information, use of committees, and training activities. The amount of variance in the average productivity score could be predicted by the contrast between parents and teachers/staff, relevant information, use of committees, training activities, school level, and level of efficiency. Additionally, there were significant differences among schools both for teachers and for parents in regards to both efficacy and productivity. 
TABLE OF CONTENTS

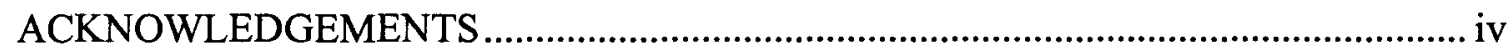

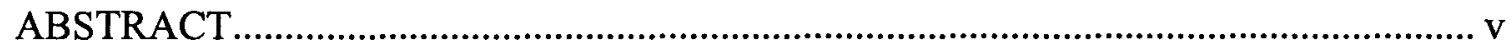

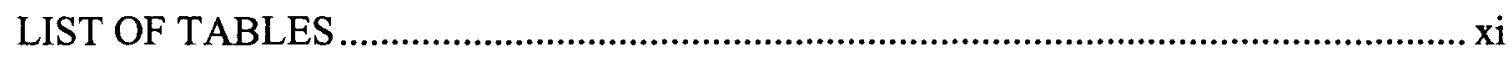

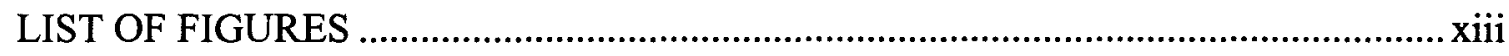

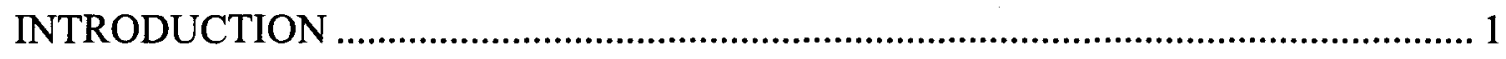

School Reform in Kentucky ............................................................................. 1

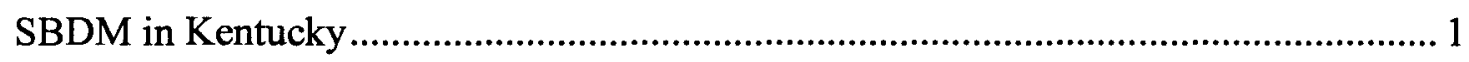

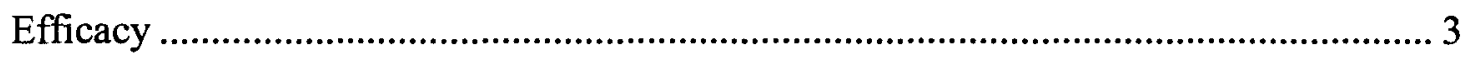

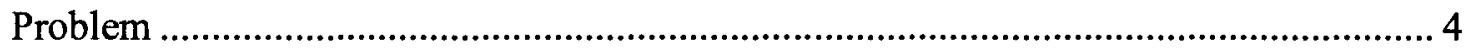

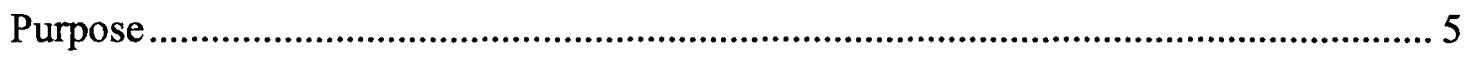

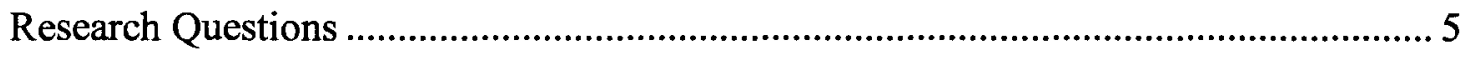

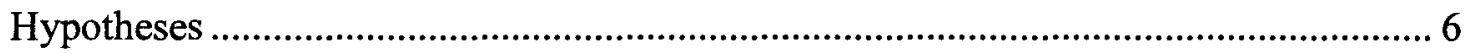

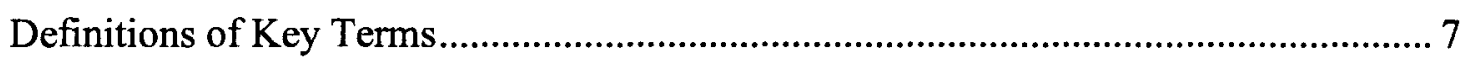

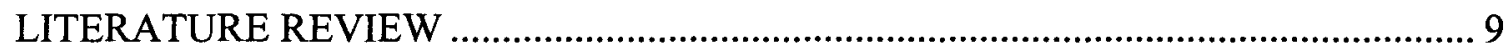

Early Decentralization Efforts................................................................................ 10

New York City, New York .................................................................................... 10

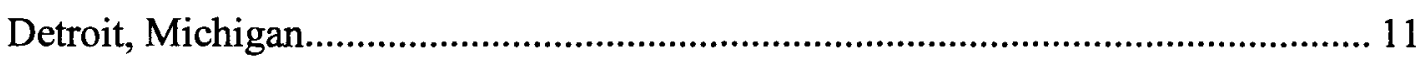

Contemporary School-Based Decision Making Throughout the United States............ 12

Dade County, Florida ........................................................................................... 13

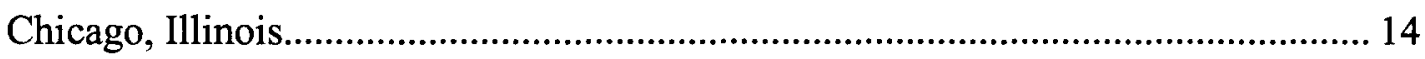




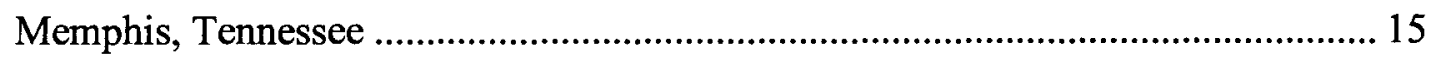

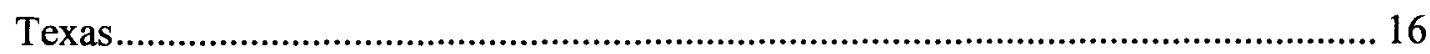

The State of Education in Kentucky before the Kentucky Education Reform Act....... 19

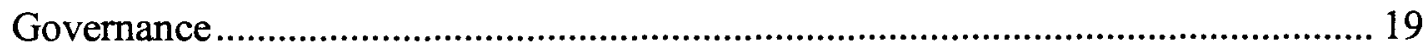

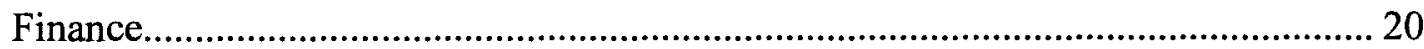

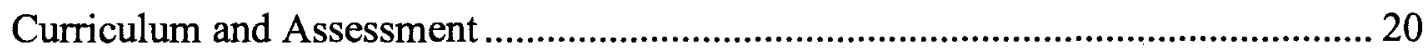

Rose v. Council for Better Education.............................................................................. 20

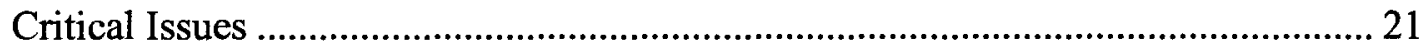

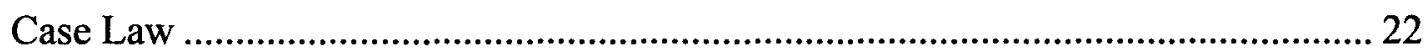

Analysis of Prior Legal and Educational Statutes ................................................... 25

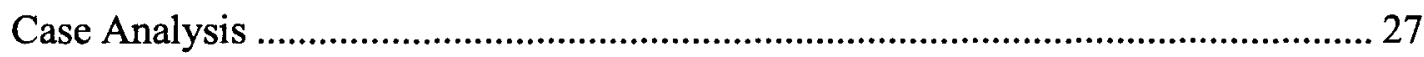

Goals for Kentucky Students ........................................................................... 28

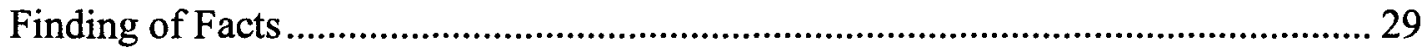

The Kentucky Education Reform Act...................................................................... 30

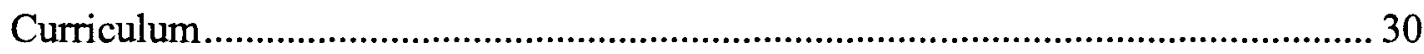

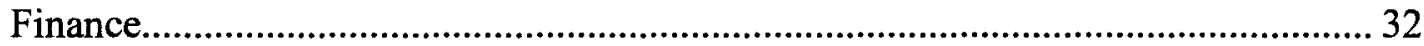

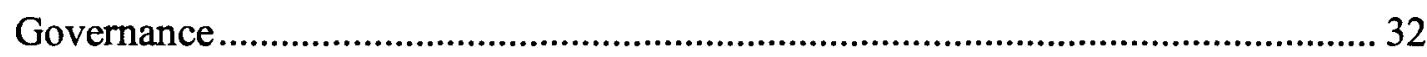

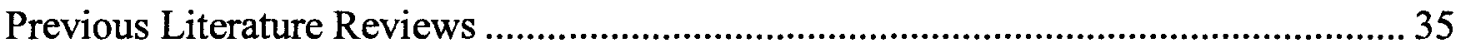

Kentucky SBDM Councils: The Implementation Years............................................. 42

The Changing Leadership Role of Parents Throughout the United States ................... 52

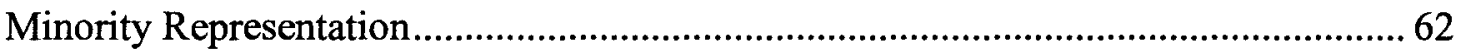

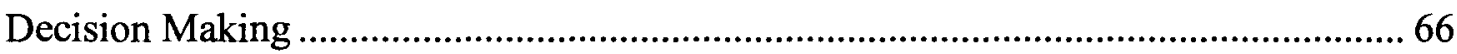

Public Education Leadership Project Research...................................................... 80

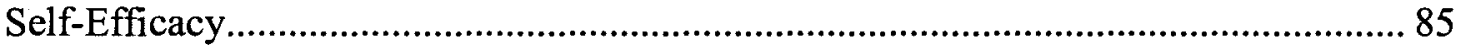

Decision Making Framework .................................................................................. 90

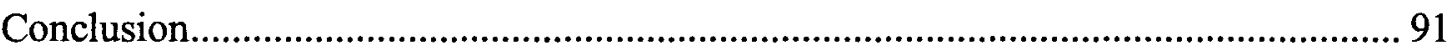

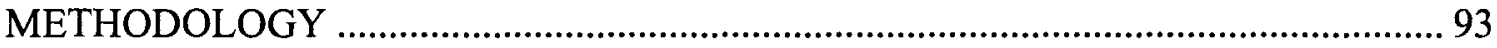

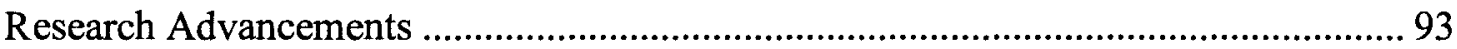

Participants and Data Collection Procedures .............................................................. 94

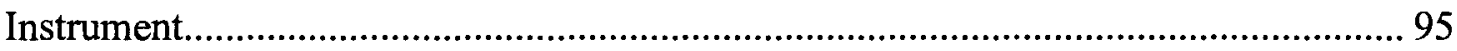




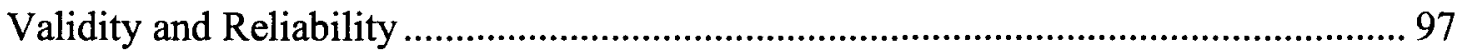

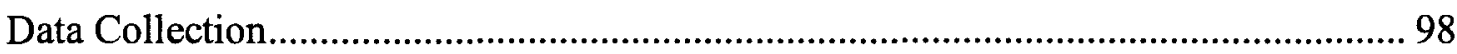

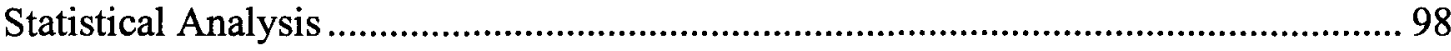

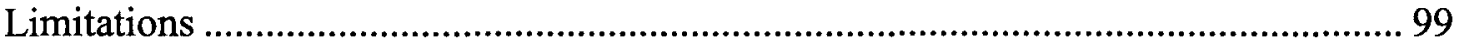

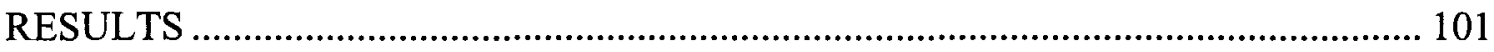

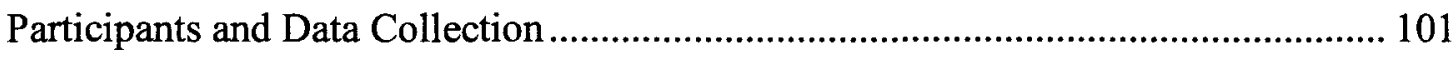

Descriptive Statistics on Demographic Variables....................................................... 102

Analysis for Research Question 1 ............................................................................. 104

Analysis for Research Question 2 ........................................................................ 108

Analysis for Research Question 3 .......................................................................... 111

Analysis for Research Question 4 ......................................................................... 116

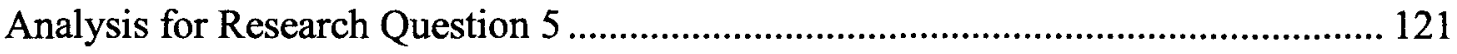

Analysis for Research Question 6 ....................................................................... 122

Possible Additional Analyses of Efficacy and Productivity Data.............................. 122

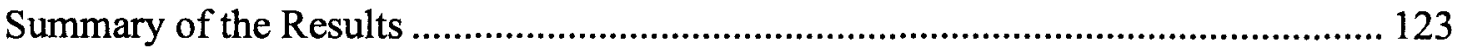

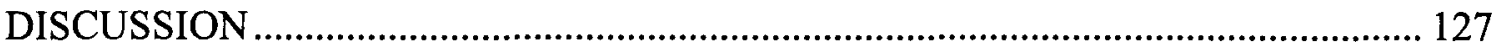

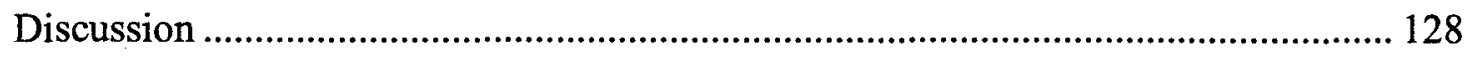

Descriptive Statistics ..................................................................................... 128

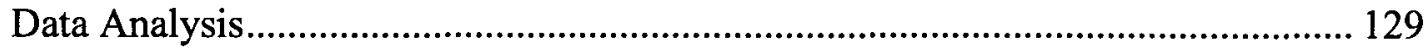

How the Study Relates to Past Research.............................................................. 131

Implications for Practice ...................................................................................... 134

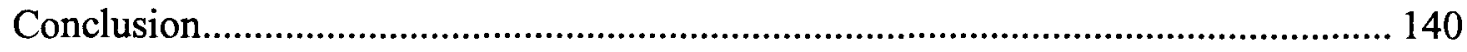

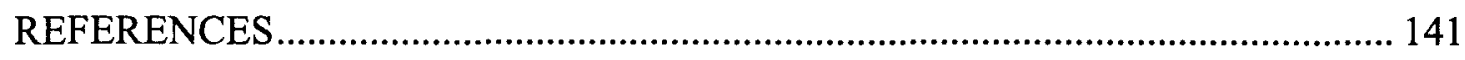

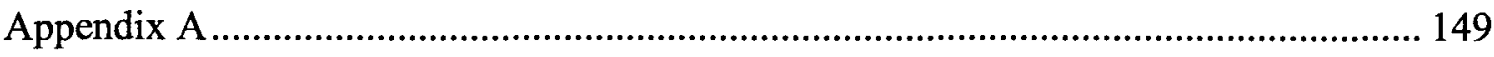

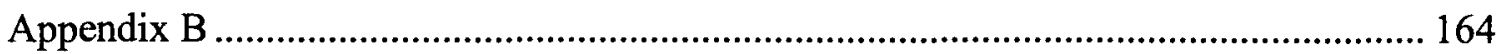

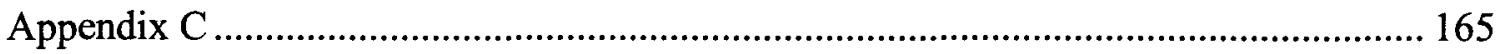

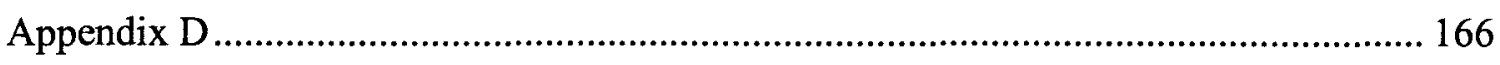

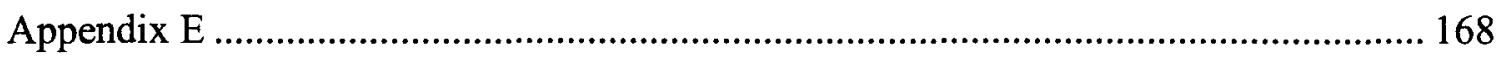




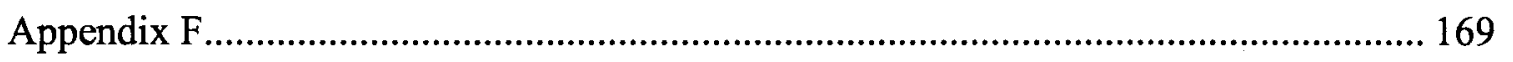

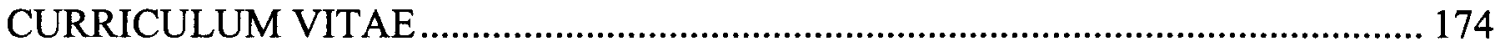




\section{LIST OF TABLES}

TABLE

PAGE

1. Comparison of School-Based Decision Making in the United States...............18

2. Frequency Distributions for Demographic Variables.............................. 103

3. Descriptive Statistics for Items on the School Council Productivity Scale...........105

4. Descriptive Statistics for Items on the School Council Efficacy Scale (SCES)......107

5. Descriptive Statistics on Groups Used in MANOVA for Research Question 2.....110

6. Means, Standard Deviations, and Correlations for Regression with Dependent

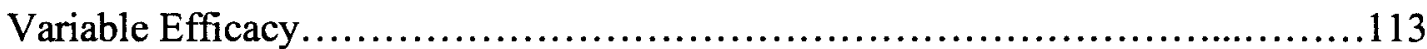

7. Partial Coefficients for Regression with Dependent Variable Efficacy..............114

8. Means, Standard Deviations, and Correlations for Regression with Dependent Variable Productivity........................................................ 118

9. Partial Coefficients for Regression with Dependent Variable Productivity..........119

10. Random Effects ANOVA for Efficacy by School...............................122

11. Random Effects ANOVA for Productivity by School..............................123

12. Results of Analyses Addressing Research Questions.............................125

F-1 Means, Standard Deviations, and Correlations for Regression with Dependent

Variable Efficacy

F-2 Partial Coefficients for Regression with Dependent Variable Efficacy With Ethnicity Defined Minority or Non-Minority. 168 
F-3 Research question 4: Means, standard deviations, and correlations for minority and

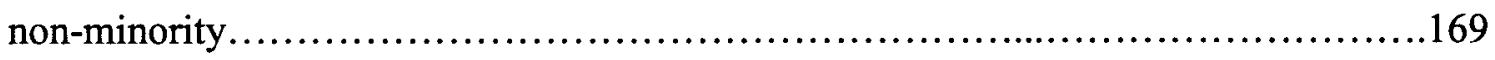

F-4 Partial Coefficients for Regression with Dependent Variable Productivity, With

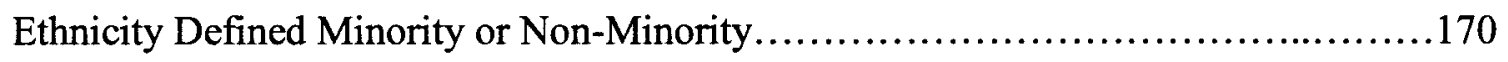




\section{LIST OF FIGURES}

FIGURE

PAGE

1. PELP coherence framework

2. Diagrammic representation of the conditional relations between efficacy beliefs and

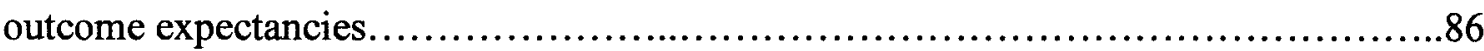

3. Operational definitions for the four types of evaluation...........................91 


\section{CHAPTER I}

INTRODUCTION

School-Based Decision Making (SBDM) brings the educational decision making process to the school level. The theory supporting SBDM is that those who are most familiar with the school should be the ones making the decisions. This creates ownership in the school for the decisions made about the school (Harrison, Killion, \& Mitchell, 1989).

\section{School Reform in Kentucky}

The Kentucky Education Reform Act (KERA) of 1990 was the most extensive and sweeping reform act in recent American history (Bjork \& Keedy, 2002; Hall \& Galluzzo, 1991; Harrington-Lueker, 1990; Pankratz \& Petrosko, 2000). Since then, other states have followed Kentucky's lead (Pankratz \& Petrosko, 2000). KERA has also inspired debates among both educators and government officials about the roles that curriculum, finance, and governance have in school reform (Russo, 1995a; Pankratz \& Petrosko, 2000). KERA was the impetus for SBDM in Kentucky.

\section{SBDM in Kentucky}

KRS 160.345 outlined the existence and implementation of SBDM councils. With few exceptions, by July 1, 1996 KERA required all schools to have in place a 
SBDM council (Harrington-Lueker, 1990). KERA gave a council of three teachers, two parents, and one administrator the power to develop school policies (KRS 160.345(2)(a)). The rationale behind moving school decision making from the district-level to the schoollevel was that those who are closer to the issues are better equipped to deal with those issues (Bjork \& Keedy, 2002; Weiss, 1993). KERA required an election to select all positions except the principal. A majority of all teachers in the building elect teacher representatives and the parents who have students enrolled or pre-registered at the school elect parent representatives (KRS $160.345(2)(b)(1))$. A school with over $8 \%$ minority student population must include minority representation on the council (KRS $160.345(2)(b)(2))$.

Under KERA, the SBDM council has the responsibility to:

1. Set school policy, consistent with district board policy, to provide an environment to enhance student achievement and to meet performance goals mandated by the Kentucky Education Reform Act;

2. Determine, within the parameters of available funds, the number of persons to be employed in each job classification within the school;

3. Select textbooks;

4. Select instructional materials;

5. Determine student support services;

6. Consult with the principal to fill teacher vacancies;

7. Select a new principal;

8. Determine the curriculum, including needs assessment and curriculum development; 
9. Assign instructional and non-instructional staff time;

10. Assign students to classes and programs;

11. Set the schedule of the school day and week, subject to the calendar established by the school board;

12. Determine the use of the school space during the school day;

13. Plan and resolve issues related to instructional practices;

14. Determine and implement discipline and classroom management techniques;

15. Select co-curricular programs and determine policies relating to student participation; and

16. Develop procedures, consistent with the local board policy, for determining alignment with state standards for student performance, technology utilization, and program appraisal. (Van Meter, 1994, p. 62)

\section{Efficacy}

Individuals do not live their lives in a vacuum and often work together to achieve desired goals. Just as those with high self-efficacy are more likely to assume more complex tasks, so are groups with high collective efficacy. According to Bandura (1998), this collective efficacy influences

the type of futures they seek to achieve; how well they use their resources; how much effort they put into their group endeavor; their staying power when collective efforts fail to produce quick results or meet forcible opposition; and their vulnerability to discouragement (p. 65).

High efficacy - either collective or individual - contributes to the success of the group. 
Individuals with low self-efficacy tend to bring doubt and lack of focus to the group.

Just as increased self-efficacy enhances the success of the collective group, parents' increased self efficacy can increase the academic achievement of their children (Bandura, 1998). If parents exercise a high belief that they can support their child's education then they increase their child's efficacy. This increased self-efficacy on the part of children then positively affects children's intellectual attainment and their social and emotional health. If parents exercise the belief that they cannot support their child's education then this belief will transfer to the child and negatively affect the child's achievement.

\section{Problem}

The problem addressed in this study is the lack of information about perceptions of SBDM functioning. Specifically, there is lack of information from individuals serving in the three SBDM positions: principal, parent, and teacher. Of these positions, the parent position is most problematic. The principal and teacher SBDM council members control the majority of the decision making on the councils. Educators control the agendas, meeting times, and dissemination of information during these meetings (Malen, Ogawa, and Krantz, 1990). The principal controls the discussions and decisions and the teachers are only able to affect the decision making if the principal remains neutral on the topic being discussed. Parents have even less power in the decision making process because educators tend to protect their professional sovereignty. Parents have difficulty expressing their concerns. When they are comfortable enough to express their concerns, parents have reported being quickly silenced (Ogawa \& White, 1994). 


\section{Purpose}

The purpose of this study is to measure the perceptions of Kentucky SBDM council members concerning the productivity and efficacy of the councils. An additional purpose is to study how perceptions of productivity and efficacy are affected by variables measured on council members. These variables include: (a) council position (principal, parent, teacher), and (b) demographic characteristics (e.g., number of years served on council). Finally, the study examines how much variability in perceptions can be attributed to individual council members and how much can be attributed to schools.

\section{Research Questions}

The research questions for this study are as follows.

1. To what degree do school stakeholders consider school councils to have efficacy and to be productive?

2. Do the various constituencies differ in their perceptions of the council efficacy and productivity?

3. How much variance in the average efficacy score can be predicted by the following independent variables: (a) age, (b) number of years served on council, (c) gender, (d) ethnicity, (e) SBDM council position (principal, teacher, or parent), (f) perception of receiving relevant information for decision-making, $(\mathrm{g})$ use of committees, (h) perception of relevance of training activities, (i) school level, and (j) level of efficiency score?

4. How much variance in the average productivity score can be predicted by the following independent variables: (a) age, (b) number of years served on council, 
(c) gender, (d) ethnicity, (e) SBDM council position (principal, teacher, or parent), (f) perception of receiving relevant information for decision-making, (g) use of committees, (h) perception of relevance of training activities, (i) school level, and (j) level of efficiency score?

5. For the SBDM council positions teacher and parent, how much variance in average efficacy score is within schools and between schools?

6. For the SBDM council positions teacher and parent, how much variance in average productivity score is within schools and between schools?

\section{Hypotheses}

Research Question 1 will be addressed with descriptive statistics that will be reported for perception ratings. For the remaining research questions, the null hypotheses are as follows.

$\mathrm{H}$ for RQ 2: There is a difference in the mean productivity and efficacy ratings of parents, teachers/staff members, and principals.

$\mathrm{H}$ for RQ 3: There is statistically significant variance in average efficacy scores attributed to the predictor variables (a) age, (b) number of years served on council, (c) gender, (d) ethnicity, (e) SBDM council position (principal, teacher, or parent), (f) perception of receiving relevant information for decision-making, (g) use of committees, (h) perception of relevance of training activities,(i) school level, and (j) level of efficiency score.

$\mathrm{H}$ for RQ 4: There is statistically significant variance in average productivity scores attributed to the predictor variables (a) age, (b) number of years 
served on council, (c) gender, (d) ethnicity, (e) SBDM council position (principal, teacher, or parent), (f) perception of receiving relevant information for decision-making, (g) use of committees, (h) perception of relevance of training activities, (i) school level, and (j) level of efficiency score.

H for RQ 5: For the council positions teacher and parent, the amount of variance between schools for average efficacy scores will be statistically significant.

H for RQ 6: For the council positions teacher, and parent, the amount of variance between schools for average productivity scores will be statistically significant.

\section{Definitions of Key Terms}

- Parent (KRS 160.345): A parent, stepparent, or foster parent of a student; or a person who has legal custody of a student pursuant to a court order and with whom the student resides.

- Self-Efficacy (Bandura, 1994): People's beliefs about their capabilities to produce designated levels of performance that exercise influence over events that affect their lives (p. 81)

- School-Based Decision Making (Covey, 1992): The decentralization/deregulation of authority and responsibility, to appropriate levels of management in specific areas from the governing board and district office, to local schools and/or support service sites. The premise of decentralization/deregulation is that those closest to, 
and most affected by, the challenges/problems in education are best qualified to develop and implement solutions to increase student achievement and success. By design, it "restructures" the governance and/or decision-making process regarding the roles, rules, and relationships for all who are stakeholders for improving and increasing student achievement (p. 15).

- School-Based Decision Making Council Responsibilities (KRS 160.345): The school council shall have the responsibility to set school policy consistent with district board policy which shall provide an environment to enhance the students' achievement and help the school meet the goals established by KRS 158.645 and 158.6451.

- Teacher (KRS 160.345): Any person for whom certification is required as a basis of employment in the public schools of the state, with the exception of principals and assistant principals. 


\section{CHAPTER II}

\section{LITERATURE REVIEW}

Malen, Ogawa, and Kranz (1990a) explained, "While there are different definitions of the term, school-based management can be viewed conceptually as a formal alteration of governance structures, as a form of decentralization that identifies the individual school as the primary unit of improvement and relies on the redistribution of decision-making authority as the primary means through which improvements might be stimulated and sustained" (p. 290). Although researched for over 50 years, there is limited research that is convincing and reliable regarding the impact it has on schools and stakeholders (Malen, 1999). The concept of decentralizing decision making is not uncommon in business and government entities who are making an effort to bring decision making to the operational level while they "stress the importance of staying close to the customer in order to improve the quality of service, while progressives support enfranchising more citizens in a democratic society" (p. 33).

The decentralization of schools is at the heart of our democratic society as the "creation of models of collaboration and participatory decision making for students to witness and become involved in-not only in classrooms but also in their communityultimately benefits not just the school community but our entire society" (David, 1996, p. 
9). One of the many reasons behind decentralization is that those closest to the situation - the teachers and building-level administrators-should have some say in the decisions made about education. It also provides parents with an official voice in the decision making process (David 2000).

\section{Early Decentralization Efforts}

The 1954 landmark decision in Brown v. Board of Education of Topeka mandated equal education for all students and an end to racial segregation in education. Although the decision was intended to improve the education of minorities, the gulf in urban schools continued to grow (Sandidge, Russo, Harris, \& Ford, 1996) as white families relocated to the suburbs in an effort to avoid desegregation (Bell, 1980). Decentralization seemed the answer to minority parents, community members, and students disenchanted with the evolving state of education because it appeared to promise moving power away from central office and giving it back to the stakeholders (Sandidge et al., 1996).

Unfortunately, the early experiments with decentralization in New York City and Detroit were unsuccessful in equalizing educational opportunities for diverse groups.

\section{New York City, New York}

In 1967 , three New York City school districts participated in a trial project with decentralization (Russo, 1995a; Russo, 1995b; Sandidge et al., 1996). When one of these Brooklyn school districts forced 19 teachers and administrators to transfer, the situation became hostile and eventually led to a two-month strike (Russo, 1995a; Russo, 1995b; Sandidge et al., 1996). The other two districts also endured frustration and hostility in their experience with decentralization (Russo, 1995a; Russo, 1995b; Sandidge et al., 
1996).

The Decentralization Act of 1969 abolished the three experimental districts and divided the city into 32 local districts (Russo, 1995a; Russo, 1995b; Sandidge et al., 1996). These local districts had the power to hire their own superintendents and retained control of the budget, curriculum, and hiring (Russo, 1995a; Russo, 1995b; Sandidge et al., 1996). Some of the districts quickly became corrupt as jobs were either purchased or given to family, friends, or constituents (Segal, 1997). This continued for almost 30 years until 1997 when scandals and investigations became public and the law changed to take budget and hiring powers away from the local boards (Segal, 1997). New York City Schools continues to recover from decades of abuse and disinterest in education (Segal, 1997). As one board member stated, 'I've never heard the word 'children' or 'education' enter into our discussions in the past few years...with anybody" (Segal, 1997, p. 142).

\section{Detroit, Michigan}

In April of 1966, Northern High School students walked out to protest the disparity between the programs and services offered to this primarily African-American school and those offered at the neighboring school with primarily white students (Russo, 1995a; Russo, 1995b; Sandidge et al., 1996). The summer of 1967 brought six days of race riots which only contributed to further dividing an already sharply divided city (Russo, 1995a; Russo, 1995b; Sandidge et al., 1996).

A push from the African-American community resulted in the creation of eight separate school districts in 1971 (Russo, 1995a; Russo, 1995b; Sandidge et al., 1996). The city maintained its regional boards and their authority over personnel, but turned 
over the control of budgets, curriculum, and students to the local school districts (Russo, 1995a; Russo, 1995b; Sandidge et al., 1996). Problems with increased spending, a lack of distribution of power, and decreased communications led to the removal of these local boards in 1981 (NCREL, 1995).

Seven years later the effort to decentralize continued with the implementation of participatory management and school-based management (NCREL, 1995). In 1989, faced with a $\$ 160$ million educational debit, the school board developed the "Memorandum of Understanding: Empowerment and Schools of Choice" (NCREL, 1995). This memorandum permitted those schools deemed successful to continue with participatory management and school-based management while those not deemed successful were reconfigured or closed (NCREL, 1995). This created unrest among the teachers and their unions resulting in only a few schools choosing to adopt this form of management (NCREL, 1995). This mistrust of conditional decentralization continues today (NCREL, 1995).

Although early decentralization efforts were unsuccessful in New York City and Detroit, a new form of decentralization emerged during the 1980s and 1990s. This new form, often referred to as Site Based or School-Based Decision Making, gave the power not to local school boards but to the schools themselves.

\section{Contemporary School-Based Decision Making Throughout the United States}

The 1983 report, A Nation at Risk, from the National Commission on Excellence in Education recommended reforms in content, standards and expectations, time, teaching, leadership, and fiscal support. Much of the report emphasized the importance 
of parental and community involvement in educational reform. The Section $A$ Word to Parents and Students directly addressed families:

You have the right to demand for your children the best our schools and colleges can provide. Your vigilance and your refusal to be satisfied with less than the best are the imperative first step. But your right to a proper education for your children carries a double responsibility. As surely as you are your child's first and most influential teacher, your child's ideas about education and its significance begin with you. You must be a living example of what you expect your children to honor and to emulate. Moreover, you bear a responsibility to participate actively in your child's education.

A Nation at Risk spoke to educated citizens about the need for educational reform in the U.S. while encouraging them to become a part of this reform.

\section{Dade County, Florida}

In 1986 the school board in the fourth largest district in the United States provided local schools the opportunity to utilize School-Based Decision Making (Russo, 1995a; Russo, 1995b; Sandidge et al., 1996). The school board required schools to have a twothirds faculty vote in support of the creation of a council and its responsibilities (Russo, 1995a; Russo, 1995b; Sandidge et al., 1996). The superintendent and president of the teacher's union had the right to approve or deny the request (Russo, 1995a; Russo, 1995b; Sandidge et al., 1996). Each council had a different degree of control, but most "assumed the ability to direct discretionary spending in the schools, to make curricular modifications, and to implement differentiated staffing, but not to dismiss school 
personnel" (Sandidge et al., 1996, p. 318). Wohlstetter (1990) found continued widespread support for SBDM among the teachers' union, community, and local businesses.

\section{Chicago, Illinois}

During the 1970s and 1980s Chicago fought increasing poverty, budget reductions, and steadily declining test scores (Blackledge, 1995; Hess, 1991; Shatkin \& Gershberg, 2007). In response to the struggling state of the Chicago Public School System, the Illinois General Assembly passed the Chicago School Reform Act of 1988 (Hess, 1991; Russo, 1995a; Russo, 1995b; Sandidge et al., 1996; Shatkin \& Gershberg, 2007). Among many new initiatives, the Act included the creation of Local School Councils (Hess, 1991; Russo, 1995a; Russo, 1995b; Sandidge et al., 1996; Shatkin \& Gershberg, 2007; Snider, 1991). The intent of the Act was:

to make the individual local school the essential unity for educational governance and improvement and to establish a process for placing the primary responsibility for school governance and improvement in furtherance of such goals in the hands of parents, community residents, teachers, and the school principal at the school level (Parents United for Responsible Education, 2006, p. 4).

These councils consisted of a principal, two teachers, six parents, and two community members (Blackledge, 1995; Hess, 1991; Russo, 1995a; Russo, 1995b; Sandidge et al., 1996; Shatkin \& Gershberg, 2007; Snider, 1991; Kaba, 2001). With the exception of the principal, each representative served a two-year term (Hess, 1991; Russo, 1995a; Russo, 1995b; Sandidge et al., 1996). Council members could not be members of the local 
school board nor could they be directly related to a school board member (Hess, 1991). Additionally, high schools had a non-voting student representative who served a one-year term (Hess, 1991; Russo, 1995a; Russo, 1995b; Sandidge et al., 1996; Kaba, 2001). The law required that a parent be the president of the council (Hess, 1991).

The Local School Councils controlled the school improvement plan, textbooks, curriculum, attendance, discipline, personnel, and professional development (Russo, 1995a; Russo, 1995b; Sandidge et al., 1996). Councils could also select a principal, renew their term, or remove them entirely (Bryk \& Easton, 1994; Russo, 1995b; Sandidge et al., 1996).

Concerns about the varying amount of community involvement on the Local School Councils and the continuing financial decline resulted in changes during the mid 1990s. Power shifted away from the Local School Councils back to the mayor and board of education (Shatkin \& Gershberg, 2007). The eventual loss of the authority over the budget led to an overall reduction of power at the school level (Shatkin \& Gershberg, 2007).

\section{Memphis, Tennessee}

During the 1989-90 school year, three elementary, two middle, and two high schools from the Memphis City School System voluntarily adopted School-Based Decision Making (Etheridge, 1995; Smith, Valesky, \& Horgan, 1991; Valesky, Smith \& Horgan, 1990). These schools served predominately low-income inner-city communities. The schools historically had struggled to meet the needs of their students (Etheridge, 1995). The councils consisted of two teachers, a community member, two parents, and 
the principal (Smith et al., 1991). The councils made personnel recommendations to the superintendent, conducted a needs analysis, developed a school plan, made curricular decisions, and proposed a budget (Etheridge, Hall, \& Brown, 1990; Smith et al., 1991). Over the next five years the rest of the 160 Memphis City Schools implemented SBDM (Etheridge, 1995).

\section{Texas}

In 1991 the state of Texas passed House Bill 2885. This law mandated "local school districts to develop and implement plans for teacher and parental participation ocommittees dedicated to some form of SBDM"' (Sandidge et al., 1996, p. 319). These committees consisted of two-thirds teaching personnel and one-third non-teaching individuals (Lutz \& Iden, 1994). The non-teaching individuals included local business and community members (Russo, 1995a; Russo, 1995b; Sandidge et al., 1996). These committees serve in an advisory capacity on topics such as budget, staffing, organization, and goals (Russo, 1995a; Russo, 1995b; Sandidge et al., 1996) and continue to function in Texas schools.

As exemplified through the early experiences in New York City and Detroit and later shown in the efforts of Dade County, Chicago, Memphis, and the state of Texas, decentralization and SBDM has been employed throughout the United States in a variety of ways and with varying degrees of success. Kannapel, Moore, Coe, and Aagaard (1995) found that "Some form of SBDM has been advocated for in nearly every major school restructuring proposal that has emerged since the mid 1980s" (p. 15). The most expansive and long-term example of SBDM is found in Kentucky (Bjork \& Keedy, 
2002). Pankratz and Petrosko (2000) concur, stating that "Most researchers, educators, and policy-makers in Kentucky would agree that a key ingredient has been the organized citizen and business support for change" (p. 279). 
Table 1

Comparison of School-Based Decision Making in the United States

\begin{tabular}{|c|c|c|c|}
\hline Location & Council membership & Selection & Authority \\
\hline Dade County, FL & $\begin{array}{l}\text { Determined by individual } \\
\text { school }\end{array}$ & $\begin{array}{l}\text { Determined by individual } \\
\text { school }\end{array}$ & Budget, curriculum, and personnel \\
\hline Chicago, IL & $\begin{array}{l}\text { One principal, six parents, } \\
\text { two community members, } \\
\text { two teachers and one non- } \\
\text { voting student at the } \\
\text { secondary level }\end{array}$ & Elected by constituents & $\begin{array}{l}\text { Principal selection \& removal, budget, } \\
\text { school improvement plan, textbooks, } \\
\text { curriculum, attendance, discipline, } \\
\text { personnel, and professional development }\end{array}$ \\
\hline Memphis, TN & $\begin{array}{l}\text { One principal, two } \\
\text { teachers, two parents, and } \\
\text { one community member }\end{array}$ & Elected by constituents & $\begin{array}{l}\text { Personnel recommendations, needs } \\
\text { analysis, school plan, curriculum, and } \\
\text { proposed a budget }\end{array}$ \\
\hline Texas & $\begin{array}{l}\text { Two-thirds teachers and } \\
\text { one-third non-teaching } \\
\text { personnel }\end{array}$ & Elected by constituents & Budget, staffing, organization and goals \\
\hline Louisville, KY & $\begin{array}{l}\text { One principal, two parents, } \\
\text { and three teachers. The } \\
\text { council may apply to the } \\
\text { state to change the } \\
\text { membership composition. }\end{array}$ & Elected by constituents & $\begin{array}{l}\text { Budget, principal selection, curriculum } \\
\text { and textbook selection, and personnel } \\
\text { consultation }\end{array}$ \\
\hline
\end{tabular}

Adapted from (2007). "Empowering parents and building communities: The role of school-based councils in educational governance and accountability" by G. Shatkin \& A.I. Gershberg, 2007, Urban Education, 42, p. 586. 


\section{The State of Education in Kentucky before the Kentucky Education Reform Act}

Prior to the Kentucky Education Reform Act (KERA) of 1990, Kentucky's public schools were among of the lowest performing schools in the country, in almost every aspect (Hunter, 1999; Russo, 1995a). Enhanced efforts to improve education in the state began as early as 1953 when the state constitution changed to base school funding on actual student attendance rather than student population (Kentucky Department of Education, 2000). Various court decisions made repeated attempts to reduce the financial gaps between the advantaged and disadvantaged districts during the 1960s and 1970s (Hunter, 1999). The General Assembly would nullify these attempts by changing the law (Hunter, 1999). The 1984 School Improvement Act eventually allowed the Kentucky Department of Education to intervene when schools were unable to meet certain performance standards (Kentucky Department of Education, 2000). Sixty-six of the most disadvantaged school districts, dissatisfied with the inadequacies in funding and the threat of state takeover, united to create the Council for Better Education (Kentucky Department of Education, 2000; Russo, 1995a; Schlinker, Kelley, O’Phelan \& Spall, 2008).

\section{Governance}

Prior to the implementation of SBDM, teachers and parents had little or no input into education (David, 2000, p. 212). The superintendent retained the authority to place and move principals and other administrative staff members (Collins, 1991). Nepotism was rampant before KERA, as evidenced by the 175 school board members who had to resign from their positions because a relative was hired during their tenure (Harrington- 
Lueker, 1990; Kannapel, Moore, Coe, \& Aagaard, 1995).

\section{Finance}

The traditional system of educational funding drew heavily from local property taxes (Hunter, 1999). As a result, the wealthiest school districts continued to have relatively adequate funding-sometimes more than two times the funding of their neighboring districts (Kentucky Department of Education, 2000). The poorer districts continued to suffer from inadequate funding while trying to meet the needs of many of Kentucky's most needy students (Kentucky Department of Education, 2000).

\section{Curriculum and Assessment}

Changes in curriculum and assessment occurred, too. These included adding nonacademic factors as well as academic factors and modifications to the testing process. There was a shift in the assessment process, including multiple subject areas instead of only reading and mathematics. Assessments included open response questions in addition to the standard multiple choice questions. The goals changed from annual goals to include biannual goals.

\section{Rose v. Council for Better Education}

Rose v. Council for Better Education, Inc. (1989) was an appeal from the lower court to determine "whether the Kentucky General Assembly has complied with its constitutional mandate to 'provide an efficient system of common schools throughout the state"" (Western Kentucky University Libraries, "Introduction," para. 1). The Supreme Court of Kentucky determined that the legislature had not met their constitutional mandate. The Court stated, "it is crystal clear that the General Assembly has fallen short 
of its duty to enact legislation to provide for an efficient system of common schools throughout the state" ("Introduction," para. 2).

\section{Critical Issues}

The four critical issues, as determined by the court, were to

1. define the phrase "an efficient system of common schools" as contained in Section 183 of the Kentucky Constitution;

2. determine if an education is a "fundamental right" under the Constitution;

3. determine if Kentucky's current method of financing its common school violates Section 183; and

4. determine whether or not students in the "poor" school districts were denied equal protection of the laws (Western Kentucky University Libraries, "Analysis of Trial Court's Findings," para. 3).

The Court determined that education was a fundamental right under Section 183 of the Kentucky Constitution; "The General Assembly shall, by appropriate legislation, provide for an efficient system of common schools throughout the state" (Western Kentucky University Libraries, "Do the Local School Boards," para. 8). The court defined efficient in reference to the Kentucky Constitution as "a system which required 'substantial uniformity, substantial equality of financial resources and substantial equal opportunity for all students"” (“Analysis of Trial Court's Findings," para. 4). It went on to define efficient as "adequate, uniform and unitary" ("Analysis of Trial Court's Findings," para. 4). The Supreme Court of Kentucky concurred with the lower court, "The history of school financing in Kentucky certainly corroborates the trial court's 
findings as to the lack of uniformity and the lack of adequacy of local and state funding of education in the state" (The Evidence, para. 21). The court determined that Kentucky's current method of financing its common schools did indeed violate Section 183 of the Constitution. As for the question of whether or not students in the "poor" school districts were denied equal protection of the laws, it was found that, "Testimony indicated that not only do the so-called poorer districts provide inadequate education to fulfill the needs of the students but the more affluent districts' efforts are inadequate as well, as judged by the national standards" (The Evidence, para. 14).

\section{Case Law}

The court cited seven decisions from other Kentucky courts were cited as precedents - City of Louisville v Commonwealth, Board of Education of Boyle County v. McChesney, Commonwealth ex. rel. Baxter v. Burnett, Wooley v. Spalding, Kentucky, Carroll v. Board of Education of Jefferson County, Pauley v. Kelly, and Major v. Cayce. These lower court decisions set the groundwork for the higher court's decision.

City of Louisville v Commonwealth, 134 Ky. 488, 121 S.W. 411 (1909) found that "All [schools throughout the state] have one main essential- that they are free schools, open to all the children of proper school age residing in the locality, and affording equal opportunity for all to acquire the learning taught in the various common school branches..." 121 S.W. at 412 ("What is an "Efficient System," para. 16). The implications of this for the Rose case are that all children have the right to an equal education, regardless of whether or not they live in an impoverished or wealthy area .

Board of Education of Boyle County v. McChesney, 235 Ky. 692, 32 S.W.2d 26 
(1930) found that "Onerous taxes are levied annually and paid willingly by the people for this essential governmental service" 32 S.W.2d at 28 (Western Kentucky University Libraries, "What is an 'Efficient System," para. 18). The service in question was an efficient school system. The implications for Rose are that taxes are to be used for an efficient school system.

Commonwealth ex. rel. Baxter v. Burnett, 237 Ky. 473,35 S.W.2d 857 (1931) found that "In the progress towards the highest degree of efficiency the legislature more and more has centralized the control of schools and sought uniformity and equality of advantage for the school children of the state as a whole" 35 S.W.2d at 859 (Lestern Kentucky University Libraries, "What is an 'Efficient System," para. 19). This case had dual implications for the Rose case. The first one being that the state was in control of the common school system and the second being that they should seek equal education for all children.

Wooley v. Spalding, Kentucky, 293 S.W.2d 563 (1956) ruled that "The fundamental mandate of the Constitution and Statues of Kentucky is that there shall be equality and that all public schools shall be nonpartisan and nonsectarian. Uniformity does not require equal classification but it does demand that there shall be a substantially uniform system and equal school facilities without discrimination as between different sections of a district or county" Id. at 565 (Western Kentucky University Libraries, "What is an 'Efficient System," para. 21). The results of this ruling were:

1. The General Assembly is mandated, is duty bound, to create and maintain a system of common school-throughout the state. 
2. The expressed purpose of providing such service is vital and critical to the well being of the state.

3. The system of common schools must be efficient.

4. The system of common schools must be free.

5. The system of common schools must provide equal educational opportunities for all students in the Commonwealth.

6. The state must control and administer the system.

7. The system must be, if not uniform, "substantially uniform," with respect to the state as a whole.

8. The system must be equal to and for all students ("What is an 'Effective System," para. 22).

Carroll v. Board of Education of Jefferson County, 410 F.Supp. 234 (W.D.Ky. 1976), aff'd 561 F.2d 1 ( $6^{\text {th }}$ Cir. 1977) states that "In short, once the citizens of Kentucky made the voluntary commitment to educate the children of this state in public schools neither the Kentucky General Assembly nor those individuals responsible for discharging the duties imposed on them by the state constitution...can abrogate those duties merely because the monetary obligations becomes unexpectedly large or onerous" Id. at 238. This affects Rose in that it forces taxpayers to pay for the educational system, no matter how expensive it becomes (Western Kentucky University Libraries, "What is an 'Effective System,"” para. 24).

Pauley v. Kelly, 162 W. Va. 672, 255 S.E.2d 859 (1979) determined that "So, on the threshold question: no court has been hesitant to affirm legislation; many have required specific actions by local boards to bring them to compliance with the 
constitutional mandate; and legislation has been declared unconstitutional because it failed the mandate. There is ample authority that courts will enforce constitutionally mandated education quality standards" Id. at 874 (Western Kentucky University Libraries, "What is an 'Effective System," para. 37). Although this was a case in West Virginia, it was found applicable to Rose because the reasoning was the same. This court also defined thorough and efficient as one that "develops, as best the state of education expertise allows, the minds, bodies and social morality of its charges to prepare them for useful and happy occupations, recreation and citizenship, and does so economically" Id. at 877 ("What is an "Effective System," para. 39).

Major v. Cayce, 98 Ky. 357, 33 S.W. 93 (1985) determined that "[U]nder the school law the pupils, all within the age and resident in the district, are entitled to attend these common schools, and to receive tuition in all the branches [of learning] prescribed by the state board of education to be taught therein, free of expenses..." $33 \mathrm{~S}$.W. at 94 (Western Kentucky University Libraries, "What is an 'Effective System," para. 14). The implication of this for the Rose case has been that it prohibits any decisions that do not allow for equal education in the common schools ("What is an 'Effective System"').

\section{Analysis of Prior Legal and Educational Statutes}

The main issue was not that Kentucky schools performed low in comparison with the national average; rather, the legal issue was that funds were inadequate and not dispersed equitably. Evidence revealed that, as a whole,

Kentucky's system of common schools is under-funded and inadequate; is fraught with inequalities and inequities throughout the 177 local school districts; is ranked 
nationally in the lower $20-25 \%$ in virtually every category that is used to evaluate educational performance; and is not uniform among the districts in educational opportunities (Western Kentucky University Libraries, The Evidence, para. 2).

The evidence presented to the court showing that education throughout the state was not equal included the discrepancy between curricula offered in impoverished districts and wealthy ones in addition to the substantially lower test scores on achievement tests in these districts. All of the witnesses testified that

...there is a great disparity in the poor and the more affluent school districts with regard to classroom teachers' pay; provision of basic educational materials; student-teacher ratio; curriculum; quality of basic management; size, inadequacy and condition of school physical plants; and per year expenditure per student (Western Kentucky University Libraries, The Evidence, para. 12).

The court concluded, "when one reads the record, and when one considers the argument of counsel for the appellants, one can find no proof, no statement that contradicts the evidence about the existing inequalities" (Western Kentucky University Libraries, The Evidence, para. 15).

Expert witnesses also felt that Kentucky's educational endeavor was inadequate and not level with other states in the nation. Most witnesses testified that the Minimum Foundation Program and Power Equalization Program were under-funded and not the answer to Kentucky's educational financial woes. Many districts adopted permissive taxes but some had not. Of the districts that had, those additional tax dollars did not raise enough money to relieve the financial burden (Western Kentucky University Libraries, 
The Evidence). Simply put, Kentucky was not spending enough money on education and the money that was spent was not allocated equally.

\section{Case Analysis}

The court determined that the issue at hand dealt entirely with the Kentucky State Constitution, not the Federal Constitution, because "School districts and other municipal corporations are creatures of the state. Except as provided by their state, they have no existence, no function, no rights, and no powers" (Western Kentucky Uinversity Libraries, "Dot the Local School Boards," para.12). The Kentucky Constitution, unlike Michigan's, directly addresses education in common schools making it a Kentucky Supreme Court issue.

This case centered upon state constitutional issues and it was the duty of the Supreme Court of Kentucky to interpret and rule upon these issues. The Court determined, though, that "the sole responsibility for providing the system of common school lies with the General Assembly" (Western Kentucky University Libraries, Summary/Conclusion, para. 6).

The Court felt that the Constitutional debates ended with the interpretation of Section 183 by Delegates Beckner and Moore:

- The providing of public education through a system of common schools by the General Assembly is the most "vital question" presented to them.

- Education of most children must not be minimized to the "slightest degree.”

- Education must be provided to the children of the rich and poor alike. 
- Education of children is essential to the prosperity of our state.

- Education of children should be supervised by the state.

- There must be a constant and continuing effort to make our schools more efficient.

- We must not finance our schools in a de minimus fashion.

- All schools and children stand upon one level in their entitlement to equal state support (Western Kentucky University, "What is an "“Efficient System"').

\section{Goals for Kentucky Students}

The Supreme Court of Kentucky agreed with the trial court that every child has a right to an adequate education and the General Assembly must protect that right. They further determined the goals for Kentucky students:

1. Students are able to use basic communication and mathematics skills for purposes and situations they will encounter throughout their lives.

2. Students shall develop their abilities to apply core concepts and principles from mathematics, the sciences, the arts, the humanities, social studies, practical living studies, and vocational studies to what they will encounter throughout their lives.

3. Students shall develop their abilities to become self-sufficient individuals.

4. Students shall develop their abilities to become responsible members of a family, work group, or community, including demonstrating effectiveness in community service.

5. Students shall develop their abilities to think and solve problems in school 
situations and in a variety of situations they will encounter in life.

6. Students shall develop their abilities to connect and integrate experiences and new knowledge from all subject matter fields with what they have previously learned and build on past learning experiences to acquire new information through various media sources (Kentucky Department of Education, 2007).

\section{Finding of Facts}

The trial court judge determined that an efficient system of schools is a " "...tax supported, coordinated organization, which provides a free, adequate education to all students throughout the state, regardless of geographical location or local fiscal resources"” (Western Kentucky University Libraries, “Analysis of Trial Court's Finding," para. 14). The Court determined that it is a child's right to an equitable and adequate education under Kentucky's Constitution. The current common school system violated that right. It was the sole responsibility of the General Assembly to protect that right. The court determined that the current system of common schools was determined to be constitutionally deficient and the Generally Assembly was to design and implement a new system that would assure that Kentucky children receive an education that was both equal and adequate. The Court did not mandate how the General Assembly was to accomplish these goals or fund this endeavor, stating only that Section 183 of Kentucky's Constitution required that it be done.

As determined in Brown v. Board of Education, "education is perhaps the most important function of state and local governments" (Western Kentucky University Libraries, "Introduction," para. 4). In 1989 the state of Kentucky was failing its children through providing an underfunded, inequitable, and inadequate education. Consider 
these statistics brought in front of the Court:

- "Children in $80 \%$ of local school districts in this Commonwealth are not as well-educated as those in the other $20 \%$ " (Western Kentucky University Libraraies, The Evidence, para. 13)

- The state of Kentucky ranked $40^{\text {th }}$ nationally in per pupil expenditures (The Evidence).

- "[O]nly $68.2 \%$ of ninth grade students eventually graduate from high school" (The Evidence, para. 9).

Considering these facts, it was no surprise that the Supreme Court of Kentucky found the current system of common schools constitutionally deficient. This ruling by the Court eventually led to the Kentucky Education Reform Act.

\section{The Kentucky Education Reform Act}

The Kentucky Education Reform Act (KERA) of 1990 was the most extensive and sweeping educational reform act in recent American history (Bjork \& Keedy, 2002; Hall \& Galluzzo, 1991; Harrington-Lueker, 1990; Pankratz \& Petrosko, 2000;). Since then, other states have followed Kentucky's lead (Pankratz \& Petrosko, 2000). It has also inspired debates among both educators and government officials about the roles that curriculum, finance, and governance have in school reform (Russo, 1995a; Pankratz \& Petrosko, 2000).

\section{Curriculum}

KERA allowed individual schools to develop and implement their own 
curriculum (Harrington-Lueker, 1990; Pankratz \& Petrosko, 2000). New School Performance Standards were developed and schools were measured according to their ability to meet these standards (Harrington-Lueker, 1990; Pankratz \& Petrosko, 2000). Assessment was based on student performance and each school was required to develop its own assessment program by the 1995-96 school year (Harrington-Lueker, 1990; Pankratz \& Petrosko, 2000). The curriculum and assessment developed was required to reveal that the students are able to "(1) use basic communications and mathematics skills, (2) apply core concepts from one discipline to another and to their daily lives, (3) become self-sufficient individuals capable of contributing to a community, (4) be able to think and solve problems in a variety of situations, and (5) connect and integrate new knowledge and experiences" (Harrington-Lueker, 1990, p. 19).

Along with changes in curriculum and assessment, KERA mandated the development of ungraded primary schools. In theory, ungraded primaries allow students to learn at their own rate (David, 1994; Harrington-Lueker, 1990; Pankratz \& Petrosko, 2000). Districts had to provide preschool programs for at-risk students (HarringtonLueker, 1990; Pankratz \& Petrosko, 2000; Van Meter, 1991). To further assist at-risk students, KERA mandated Family Resource/Youth Service Centers (Harrington-Lueker, 1990; Shatkin \& Gershberg, 2007; Van Meter, 1991). These centers provided services to assist students and their families by "providing day care, family and employment counseling, and social service referrals" (Harrington-Lueker, 1990, p. 19).

Kentucky allocated more than $\$ 100$ million dollars to improve the use of technology in schools across the state (Van Meter, 1991) and also allocated funds for the Extended School Service Program to provide tutoring for high-risk students (Pankratz \& 
Petrosko, 2000).

\section{Finance}

KERA created a system of rewards for schools that met their goals and repercussions for schools that did not meet their goals (Harrington-Lueker, 1990). Schools designated as failing, "lose the right to design their own programs and might be forced to accept state help or be subject to a state takeover" (Harrington-Lueker, 1990). Additionally, KERA provided that failing schools be at risk of losing their students as families are then provided the opportunity to transfer to other schools (HarringtonLueker, 1990). The state funding allocated for the student transfers based on the new state funding formula (Harrington-Lueker, 1990).

KERA created the Support Education Excellence in Kentucky (SEEK) formula to equalize the funding for each school (Pankratz \& Petrosko, 2000). This formula based state funding on the previous year's attendance with extra funding provided to meet the needs of at-risk and disabled students (Pankratz \& Petrosko, 2000; Van Meter 1991).

\section{Governance}

The General Assembly enacted anti-nepotism laws to reduce corruption within school boards in the area of hiring staff (Harrington-Lueker, 1990). Individuals could no longer run for the local school board if a relative was employed in the same district (Harrington-Lueker, 1990). Although local boards retained the power to select the superintendent, they did not retain the rights to make personnel decisions (HarringtonLueker, 1990). 
School-Based Decision Making. KRS 160.345 outlined the existence and implementation of School-Based Decision Making (SBDM) councils. With few exceptions, by July 1, 1996 KERA required all schools to have in place a SBDM council (Harrington-Lueker, 1990). KERA required a council configuration consisting of 3 teachers, two parents, and one administrator who were given the power to develop school policies (KRS 160.345(2)(a)). The rationale behind moving school decision making from the district-level to the school-level was that those closest to the issues were better equipped to deal with those issues (Bjork \& Keedy, 2002; Weiss, 1993). KERA mandated

- That the principal be a council member;

- A majority vote of all teachers in the school elect the teacher representatives;

- Parents with students pre-registered at the school elect the parent representatives; and

- That schools with more than $8 \%$ minority have minority representation on the council (KRS 160.345(2)(b)(2)).

Responsibilities of the SBDM Council. KERA gave the SBDM council responsibility to:

1. Set school policy, consistent with district board policy, to provide an environment to enhance student achievement and to meet performance goals mandated by the Kentucky Education Reform Act;

2. Determine, within the parameters of available funds, the number persons to be 
employed in each job classification within the school;

3. Select textbooks;

4. Select instructional materials;

5. Determine student support services;

6. Consult with the principal to fill teacher vacancies;

7. Select a new principal;

8. Determine the curriculum, including needs assessment and curriculum development;

9. Assign instructional and non-instructional staff time;

10. Assign students to classes and programs;

11. Set the schedule of the school day and week, subject to the calendar established by the school board;

12. Determine the use of the school space during the school day;

13. Plan and resolve issues related to instructional practices;

14. Determine and implement discipline and classroom management techniques;

15. Select cocurricular programs and determine policies relating to student participation; and

16. Develop procedures, consistent with the local board policy, for determining alignment with state standards for student performance, technology utilization, and program appraisal. (Van Meter, 1994, p. 62)

When interviewed by Lindle (1994), parent Mark Bongard explained, "The school-based decision-making part of this reform is right on the level that makes the most difference. This way teachers and parents have to talk to each other about the issues that 
really matter" (p. 22). Another parent in that same study concurred,

School-based decision-making is the 'blood and guts' of KERA. I go to the meetings to find out about the everyday operations of the school that most patents never get to know about. Even the most mundane issues reveal that human beings work in the school. And you can affect how a teacher teaches your own child (p. 21).

To parents, KERA signified a new level of involvement in their child's education.

\section{Previous Literature Reviews}

Malen, Ogawa, and Krantz (1990b) reviewed over 200 documents relating to SBM in the United States, Australia, and Canada. They found that the literature supporting SBM indicates that it

- enables site participants to exert substantial influence on school policy decisions;

- enhances employee morale and motivation;

- strengthens the quality of school-wide planning processes;

- stimulates instructional improvements;

- fosters the development of characteristics associated with effective schools; and

- improves the academic achievement of students (p. 32).

Their findings on parental involvement were not as positive as their other findings. Malen and his colleagues determined that even with the best of intentions educators still control the SBDM agenda, meeting time and location, and dissemination of the information. Parents are unwilling to break the mold where the teachers teach and 
the administrators make all decisions. Even if they were willing to, they do not have the time, expertise, or support necessary to be active participants.

In 1990 Malen, Ogawa, and Kranz (1990a) conducted a case study of the current literature on school-based management. They utilized a technique called snowballing, where they explored the current literature on school-based management and explored the references cited in the literature. They sought to answer two questions: (1) "What do we know about school-based management?" and (2) "How might we understand and interpret this reform?" (p. 289). Four major themes occurred throughout the literature:

1. School-based management is a recurrent and widespread reform strategy;

2. Because school-based management is, empirically, an elusive nation, it is extraordinarily difficult to determine the extent to which school-based management plans fundamentally alter decision making arrangements;

3. Where school-based management plans identify formal alternations in decision making arrangements, they alter these arrangements in a variety of ways; and

4. When the 'theories of action' embedded in school-based management proposals are examined in light of existing data, evidence regarding the ability of this reform to achieve its stated objectives is severely limited (p. 296).

The literature also suggests that School-Based Management usually results from a tumultuous atmosphere. From this tumultuous atmosphere, SBM has evolved and continues to evolve. Until this evolution becomes more concrete in terms of what authorities the schools have, it will remain impossible to map these authorities. Many schools have the power to develop school improvement plans but not the jurisdiction to 
develop school budgets. It is difficult to ascertain whether or not the schools currently have a greater decision making capacity than before because the availability of previous data is limited.

The distribution of power varies from school to school. In some cases the principal retains the power and the council acts in an advisory capacity. In other schools the council retains the authority to hire and fire the principal. The composition of the councils also varies in size and participants. Often teachers, non-instructional staff members, students, parents, and community members are council members. Previous research revealed that SBM provides stakeholders the opportunity to participate in the development of school policies and decision making. However, this opportunity may be in theory only. Malen, Ogawa, and Kranz found that "even though school-based management delegates formal policymaking authority to governing councils, these councils operate more as ancillary advisors or pro forma endorsers than as major policymakers or primary policy actors" (p. 305). The decisions made by councils were mundane and trivial and rarely dealt with issues such as curriculum or instruction. The principals retain primary control of the council agendas, discussions, and decisions. Teachers only affect the decision making process if the principal remains neutral on the topic under discussion. Parents have even less power in the decision making process as educators tend to protect their professional sovereignty.

School-Based Management does create genuine opportunities for stakeholders to feel involved. It provides an arena in which concerns can be addressed and discussed. It also helps parents to better understand the complexities at the school and teachers and administrators to better understand the parent/community perspective. The council also 
serves as a symbol of democracy, where all stakeholders can be heard.

Previous research identified these negative aspects to School-Based Management:

a. the time-consuming character of the process;

b. the confusion, anxiety and contention generated as both site participants and district employees attempt to define their new roles;

c. the dissonance created as committee demands compete with teaching responsibilities;

d. the stress produced by high expectations, i.e., site participants will solve seemingly intractable problems, and uncertain technologies, i.e., there is limited and contradictory information regarding solutions to those intractable problems;

e. the resentment generated if site participants perceive they have only modest influence on marginal matters; and

f. the frustration produced by fiscal constraints, i.e, operating in a 'fiscal straightjacket' (p. 312).

Additionally, councils struggle with school improvement planning, as many do not have the time, skills, and support needed.

Implementing School-Based Management is more likely to be successful in schools that are classified as effective but it is difficult to determine a causal relationship. Ogawa and White (1994) reviewed the previous research on School-Based Management. Through their research, they identified four major themes: "(1) the lack of evidence on the efficacy of school-based management; (2) the popularity of the reform; (3) the 
diversity of school-based management; and (4) the difficulty of defining the concept" (p. 53).

The researchers review of the literature indicated that "Evidence on the efficacy of SBM programs is not compelling" (p. 54). Despite this, it is a very popular form of school reform and at the time of this study one-third of all school districts in the United States had employed some form of SBM. The councils are as diverse as the schools that utilize them. The major differences are in the areas of council authority, the degree of their authority, the composition of the councils, and the purpose of the councils.

The composition of the councils varies significantly in size and members. Some councils include educators only while others involve parents, students, non-certified personnel, community members, and local business owners. The degree of control also varies, with some councils acting in an advisory role to the principal and others delegating the role of chairperson to non-educators. Some members are elected while others are appointed or volunteer. Many utilize committees as a way to involve additional stakeholders.

The decision making power among councils also varies. Some have authority to set policy above the local school board while others act in an advisory role only. The majority of councils have authority over the school budget, personnel, and instruction. Even within these areas the council authority varies, with some given complete autonomy over every aspect of the budget or the ability to hire or fire the principal. Most all councils studied had to comply with the local school board and state mandated policies, but several obtained permission to apply for a deviation from local school board policies. 
Most councils report a flow of information down from the local school board and then upward from the council.

The research indicated that councils are often educated about instruction and decision making but not about district operations. School councils receive training in a variety of formats.

Malen (1999) conducted a review of the current literature on site-based councils to answer the questions, "Do site-based councils actually enable teachers and parents to exert significant influence on significant issues? If so, how? If not, why not?" (p. 209). Malen's research of the literature led her to determine that site-based management has not lived up to its goals. The principals still develop school policy and control meeting agendas. The teachers and parents act in an advisory capacity. Council members express that only non-important issues are brought up at the council meetings. Parents have difficulty expressing their concerns and, when comfortable enough to do so, they report being quickly silenced. Parents are often limited to a learning and advisory role, particularly parents of low-come and minority students.

The councils are capable of making change in the schools, but not changes that improve the education of the students. This is not to say that the councils are not beneficial to the schools as a way for parents, teachers, students, and community members to express their concerns. Teachers are hesitant to express their concerns, though, for risk of being seen as a troublemaker. While this is the norm, there are exceptions. Several studies document councils that are actively involved in both the development and implementation of school policy. Council members usually are initially 
excited about their newfound power but eventually begin to resent the time commitment.

Briggs and Wohlstetter (2001) compiled a review of the current literature on SiteBased Management to develop key elements of success. They determined that

1. Successful SBM schools have an active, living vision focused on teaching and learning that is coordinated with district and state standards for student performance (p. 356)

2. Successful SBM schools have decision-making authority in the areas of budget, curriculum, and personnel, and they use that authority to create meaningful change in teaching and learning (p. 357).

3. Successful SBM schools disperse power throughout the school organization by creating networks of decision-making teams (p. 359).

4. In successful SBM schools, the development of knowledge and skills is an ongoing process oriented toward building a school-wide capacity for change, creating a professional learning community, and developing a shared knowledge base (p. 360).

5. Successful SBM schools have multiple mechanisms for collecting information related to school priorities and for communicating information to all school stakeholders (p. 362).

6. Successful SBM schools use both monetary and non-monetary rewards to acknowledge individual and group progress toward school goals (p. 363).

7. In successful SBM schools, school leadership is shared among administrators and teachers. Principals often take on the role of manager and facilitator of change, while teacher leaders often take on responsibilities around issues of teaching and 
learning (p. 364).

The early literature indicates that educators retained control over the council and the decision making process. The principal controlled the agenda, discussion and agenda. Parents had difficulty expressing their concerns and, when they were comfortable enough to express their concerns, they reported being silenced quickly. They reported time constraints, lack of expertise, and lack of support as barriers to their involvement in the decision making process. While these were issues of concern, participating on the council provided parents the opportunity to better understand the complexities at the school and teachers and administrators the opportunity to better understand the parent/community perspective.

\section{Kentucky SBDM Councils: The Implementation Years}

Although KERA passed in 1990, districts had until 1996 to fully implement the SBDM councils in the schools. The studies about parental involvement in SBDM focused primarily on the challenges, successes, decision making, and lessons learned between 1990 and 1996. The information was largely obtained through surveys, observations, and interviews. This research was the first time Kentucky was part of the research conversation.

Lindle's study, Challenges and Successes with Including Kentucky's Parents in School-Based Decision Making: Pilot Year School Councils Respond, reviewed questionnaires distributed to the 1991-92 SBDM councils (1992a). The 1991-92 school year was the pilot year for the councils, as districts had until the 1995-96 school year to fully implement SBDM councils as the governing bodies of the schools. Sixty-six of the 
176 school districts in Kentucky participated in the study. Lindle acknowledged that these 66 schools ( 43 elementary, six middle, and 17 high) were not representative of what was occurring across the state. The research was valuable, however, by providing suggestions to schools on how to more effectively involve parents in the decision-making process.

The question Lindle's research addressed was, "Do School Councils include only the required two parents in the decision making process or do they make efforts to broaden parent participation?"' (p. 4). She used a non-random, open-ended questionnaire to solicit information from school council members. The results showed that school councils used two to three formats to notify non-council parent members of council meetings and only one or two methods to notify non-council parent members of the decisions made at the meetings. Further analysis of data, such as standard deviation and descriptive statistics about the councils surveyed (i.e. geographic region and school level), as not provided. Additionally, it was difficult to determine who answered the questionnaires on behalf of the councils. There could be differences between the answers given by the administrators and the parents. With such a small sample the data could change dramatically if this information was clear.

Lindle found some schools attempted to better notify and involve their parents of council meetings and decisions. The strategies included implementing activities to build parents' confidence, establishing a community relations committee, developing a key communicators network, initiating an 'information hotline,' providing orientation and training for parents, using a suggestion box, posting school council information in local businesses, and using a telephone chain or tree" (p. 4). Lindle suggested that school 
councils increase their attempts to communicate meeting dates and decisions to parents to at least seven different ways. The school councils surveyed suggested that councils use "local newspapers, radio stations, cable TV ads, school marquees, a key communicators network, posters in local businesses, and a school answering machine or service" (p. 6).

Another study by Lindle (1992b) that same year surveyed Kentucky principals, parents and teachers. Lindle used a modified version of the Communication Satisfaction Inventory. Demographic data provided indicated that 211 of the 385 council members surveyed completed the survey. Seventy-three respondents were parents, 70 were teachers, and 67 were principals. Although these numbers are roughly equal, they are not from the perspective of the composition of the school council, where membership is $1 / 6^{\text {th }}$ administrative, $1 / 3^{\text {rd }}$ parent, and $1 / 2$ teacher representatives. This study is a continuation of Lindle's previously mentioned work.

This study revealed positive efforts on the part of the school to include parents. In an effort to increase attendance of council members and other interested stakeholders, the school scheduled council meetings at times that were most convenient for parents. There was an increased willingness of parents to share in the decision-making process. Parents were given the opportunity to speak at meetings but they were rarely asked to present to the council. They received materials necessary for the meeting and occasionally provided with dinner or transportation, but never childcare services. The council encouraged parents to become part of council committees and many did so.

As in Lindle's 1992 study, educators expressed concern that parents were not knowledgeable enough about educational issues to make decisions. The survey 
responses, though, were far more positive than the observations and interviews in Lindle's previous study, which is unusual since they were conducted during the same year and by the same researcher. This discrepancy could be due to a lack of understanding on the part of the parents regarding the role they play in decision-making.

In August of 1995, the Kentucky Institute for Education Research published its study The Implementation of Kentucky's School-Based Decision Making Program. Through random selection, thirty-one schools throughout Kentucky participated in this study. Researchers interviewed parents, teachers, and administrators. Participants also completed surveys. The researchers sought

1. To determine the status of implementation of SBDM in a random selection of high schools, middle and junior high schools, and elementary schools geographically distributed throughout the state.

2. To determine patterns of implementation of various SBDM components such as policy development, focus of SBDM council meetings, process used in making decisions, and similar issues, and

3. To determine the perceived levels of support SBDM council members received in the implementation of the SBDM program (p. 10).

The results indicated that councils members take pleasure in being part of the SBDM council, but admit that membership can be time consuming. Decisions made at the meetings focused on operational issues and rarely dealt with curriculum or instruction. Council members also expressed disappointment in the lack of parent and community attendance at the SBDM meetings. 
In their four year qualitative study, Kannapel, Moore, Coe, and Agaard (1995) researched SBDM decision making in four rural Kentucky councils during the initial implementation of KERA. They studied 20 schools in four districts to answer the following research questions

(a) Are decisions, in fact, shared among the groups represented on rural school councils?

(b) What kinds of decisions do rural school councils make?

(c) What evidence exists that those decisions will have a positive impact on schools? (p. 16)

To do this they classified council decision making as balanced, educator-dominated, or principal dominated. Balanced councils were "those in which all participants (i.e. principals, teachers and parents) contributed relatively equally to discussions and the decision-making process" (p. 17). Educator-dominated councils involved teachers "in the decision-making process with the principal, but parents remained on the fringes, often without adequate information to make informed decisions" (p. 17). Councils that were principal-dominated "essentially acted as advisory committees to the principal" (p.17).

Of the twenty schools studied, only one of the SBDM councils studied was categorized as balanced. This elementary school had a history of high parental involvement-parents were so involved that teachers expressed concern that the parents would attempt to control the decision making process. Although there was turmoil and mistrust in the beginning, attitudes improved, as indicated by one parent's explanation of the meetings 
It was just kind of a little bull session, you know, where everybody would talk. And [the teachers] would say things off the record—what was going on at the school that we as parents didn't understand or know about...That really helped us congeal as a group and trust one another in making decisions (p.17).

The researcher contributed much of the success of the council to the principal, who acted as a facilitator, and to the willingness of the teachers and parents to be active in the decision making process. These decision-making powers did not come without consequence, as one parent council member noted that other parents disliked her when she did not vote to hire a local applicant, instead voting to hire a more qualified applicant from outside the district.

Councils identified as educator-dominated lacked parental involvement in the decision making process. Observations revealed that while teachers were active participants in council conversations with the principal, parents rarely spoke. One parent summarized her feelings about the decision making process

I feel like on site-based that the teachers already have an idea of what's going on. When we come in, they've already discussed it. I feel sort of left out sometimes. Some of the policies that they were presenting to us, they had already tried those out (p. 18).

Often, parents did not seek out their positions on the council or committees, but had to be recruited.

Principal-dominated councils serve in an advisory role to the principal. One teacher summarized the role of teachers and parents on these councils: 
Our site-based doesn't do much, our site-based just sort of rubber stamps...We've sort of abdicated the leadership to [the principal] and [he] brings up stuff and we discuss it and if we don't like it, it usually comes around to us rubber-stamping $\operatorname{him}($ p.19).

Another parent summarized the dynamics of the council meetings

I think when we come to the meeting that everything is pretty much cut and dried. I think most of the decisions are already made before we get here and it's just a formality of putting it before the board. And if anybody disagrees, it seems like you're talked to until you finally say, "Well, maybe that's right"...The principal is in control and he's going to talk you around to his point of view one way or the other, or else put it on the [back] burner and let you forget about it (p. 19).

Both teachers and parents privately expressed their unhappiness and frustration with council decision making.

Initially, councils of each type focused their decisions primarily on non-academic decisions, such as personnel and discipline. During years two and three the balanced and educator-dominated councils participated in decisions about the school budget, instruction, curriculum, and scheduling. The balanced councils tended to focus on and monitor curriculum.

Although unable to determine the long-term, positive impact council decisions may have on schools, Kannapel, Moore, Coe, and Aagaard discerned that, when implemented in a balanced manner, it did improve both teacher and parent involvement in decision making. 
Lindle, Gale, and Curry-White (1994) analyzed the results of the School-Based Decision Making Survey. The researchers distributed this survey in the fall of 1994. They surveyed one thousand seven hundred and forty-one Kentucky parents, teachers, and superintendents along with principals from schools that did and did not participate in SBDM. The results were primarily positive with teachers, principals, and superintendents reporting a high success rate with the implementation of SBDM. Parents and principals from schools that had not yet implemented SBDM reported a lower success rate. Teachers report a higher satisfaction rate with SBDM communications and participation than parents. There were additional discrepancies between parent and teacher perception. Parents often reported that they received no information about the budget process while teachers reported that the council had supreme control over the budget. Teachers and parents agreed that they were significantly less involved in the area of personnel than the principal. Principals indicated limited success in involving parents. The parents had positive reports of the principals but not of other parents and central office staff.

Teachers and parents became council members for very different reasons. Teachers were more likely to report that they ran for the council to involve themselves in the decision making process while parents reported the need to be involved in student learning and KERA.

Over half of the parents reported involvement in consultation (56\%) and principal selection (55\%). Less than half of the parents reported involvement in KERA policy development (43\%). Only $20 \%$ indicated that they participated in the "alignment with state and local policies and standards" (p. 36). Committees make the majority of 
discipline, curriculum, textbook, and extra-curricular decisions and principals focus on personnel and student assignment as well as scheduling. This is not an indication of the lack of parental desire to be involved, as they strongly disagreed with the statement "I feel I don't have as much to contribute to discussions as other School Council members" (p. 45).

In 1995, the Prichard Committee for Academic Excellence published Keepin' On: Five Years Down the Road to Better Schools. This report detailed the findings of the Task Force on Improving Kentucky's Schools and the Task Force on Restructuring Time and Learning. The Committee based their findings on observations and interviews that occurred over the first four years of KERA.

The Task Force identified the two goals of SBDM as

1. Giving local teachers, who are legally accountable for student learning, the authority and capacity to decide how to provide instruction, and

2. To engage the broader school community, especially parents, in schools. Two parents serve on each council; others may participate on committees. Engaging the broader parent community in schools does not occur simply because a school council exists. Increasing parent involvement remains a major challenge (p. 22).

While the research affirmed that schools successfully worked toward these goals, it admitted that parental involvement was still dismally small.

Research also identified the characteristics of effective school councils as

1. Leadership that focuses attention on student learning. 
2. Placing high priority on setting policy, coordinating, and approving recommendations.

3. A dynamic and interconnected committee structure.

4. An effective communication network inside and outside the school.

5. Strong parent representation on committees and communication with other parents.

6. Access to new knowledge and professional development (p. 28).

Although not quite satisfied with the extent of parental involvement on councils and committees, the researchers remained hopeful:

Councils can also guarantee that the parent community will have a voice in the progress of change, even if it is not yet a loud voice. Moreover, a council can ensure ownership of an agenda for change that goes beyond the principal, so that inevitable turnover in principals does not halt progress. Finally, when a council and its committees function effectively, the council becomes a powerful vehicle for rallying faculty and parents around improvement goals. School councils alone cannot bring about school transformation. But without them, such change is less likely to occur (p. 27).

\section{Lindle's 1996 article, Lessons from Kentucky About School-Based Decision}

Making, summarized her research about the first six years of SBDM in Kentucky. Among her discoveries was the confusion about the implementation of KERA at the school level among parents, teachers, and even administrators. In terms of decision making power, teachers feel that their attempts to make any substantial contributions are 
quickly thwarted. Parents have additional concerns, with one parent stating

the teachers have their lawyer [usually provided by the state affiliate of the National Education Association] and the principal has his or hers [usually provided by the school board], but parents have no one to tell us what this law or that regulation means. And no one to help us to decide if the teachers' lawyer and the administration's disagree (p. 22).

While early studies involving parental involvement in the SBDM focused primarily on the challenges, successes, decision making, and lessons learned between 1990 and 1996, later studies continued this research but looked further into school practices to communicate with parents, further implementation of the councils, the various roles of council members, and what factors encouraged or inhibited parents to become involved in their child's education.

\section{The Changing Leadership Role of Parents Throughout the United States}

While working on the Prichard Committee, Sexton (2000) compiled information about KERA to determine the strengths and areas for growth. He determined that although parent participation on the councils has increased, it has not increased enough. Additionally, there is still limited interest on the part of the teachers and parents in the elections. This could be due to the limited awareness on the part of the public about the reform.

Sexton also determined that there were many successes in the reform. The biggest success of KERA that the reform remains and has not wavered. That could be a result of the continuing public support for the movement and the political support it has 
received. Parents remain involved both as council and committee members. The number of parents who attend SBDM trainings is in the thousands. This training educates parents on data analysis and student achievement. Local businesses and the media continue to support the reform efforts.

Dauber and Epstein (1993) utilized the School Practices to Communicate with Parents and Involve Them at School (SCHCOMMPI), School Practices to Involve Parents at Home (SCHHOMEPI), Total School Program to Involve Parents (SCHTOTPI), Parent Attitude about the School (PATT), and Family background measure: Parent Education, Marital Status, Family Size, Parent Work outside the Home, and Parent Ratings of Student Ability scales in their study Parents' Attitudes and Practices of Involvement in Inner-City Elementary and Middle Schools. Nine schools participated in the research.

Dauber and Epstein determined that parent education level impacted the level of involvement in their child's education. Parents who had fewer children were more likely to participate in their child's education at home. Parents who worked were less likely to be involved in their child's education at school. Marital status was not a predictor of parental involvement in school or at home. The researchers found that the "strongest and most consistent predictors of parent involvement at school and at home are the specific school programs and teacher practices that encourage and guide parent involvement" ( $p$. $61)$.

Parents' perceptions of the school also affected their level of involvement. If the parents felt that the school was not involving them then they became less involved in 
supporting their child's education at home. The more the school involved the parents, the more the parents became involved in their child's education at home. Parents who participated in their child's education both at home and at school reported a positive school climate. This increases even more when parents perceive that the school involves them in their child's education. The school's ability to involve parents contributes more to students' educational achievement than all other factors.

The teachers in the researcher's previous study indicated that parents chose not to be involved in their child's education. This study contradicted that perception, as the parents indicated they wanted to be more involved but did not have the information necessary to do so.

Johnson and Pajeres (1996) conducted an in-depth analysis of the implementation of shared decision making at a large public high school located in the southern United States. The researchers used interviews, observations, and document analysis over three years to determine the factors that led to the support or constraint of shared decision making. They also explored the resulting changes in the school culture.

Nine of the 12 council members were teachers, each selected because of their position as department chair. The rest of the council consisted of one parent, one student, and one non-instructional staff member. Interviews conducted at the close of the school year indicated that there was a high level of support for shared decision making, even among those who had initially opposed it. One teacher commented, "When you have so many heads thinking, you are bound to get some very good ideas" (p. 607). Another teacher stated that she and her colleagues "all feel that...wow, we have a place to make 
our voices heard" (p. 608). An administrator stated, "I believe that, if people feel that a product is theirs, they will do whatever is needed to make it successful. That's why I definitely think SDM will be a very positive force in our school" (p.608). Although the instructional staff members embraced shared decision making because it gave them a voice, the parent, student, and non-instructional staff members did not share that opinion.

During the fall of the $2^{\text {nd }}$ year of implementation the council established committees—attendance, curriculum, discipline, student advisement, and budget. Committees experienced varying degrees of success. One committee was so successful it received attendance waiver requests passed by the board of education. The chair of the committee noted this as a "personal victory" (p. 612) and the result both empowered and motivated the other committees. Unfortunately, as with the council itself, the committees underrepresented parents, students, and non-instructional staff members. Johnson and Pajares state that, "However, SBM Committee activities did provide opportunities for many to participate in the decision making processes, and the matters addressed by the committees were subjected extensively to the force of argument" (p. 615). The participation of all stakeholders enhanced SBM in the decision making process, the utilization of democracy, and the support of the principal and the resources he provided. The problems that occurred were largely due to time constraints, lack of support for reform, discomfort with debating, and the school community's distrust of the district. The implementation of SDM increased the leadership in the building, encouraged all stakeholders to work together, and increased involvement in decision making.

Ovando and Abrego (1996) conducted interviews, observations, and document reviews at two rural elementary schools. They chose the schools because they were 
located in the same district in south central United States, had a student population of at least $90 \%$ Hispanic, had implemented site-based management for 3 or more years, had no changes in administration during those three years, and had at least $90 \%$ of the student population classified as economically disadvantaged. The research questions they sought to answer were

1. What do parents perceive their involvement role to be within the context of sitebased decision making?

2. What do teachers perceived the role of parental involvement to be within the context of site-based decision making?

3. What do principals perceive the role of parental involvement to be within the context of site-based decision making?

4. To what extent are there differences in parental involvement roles for minorities?

5. To what extent do parents, principals and, and teachers identify the parental involvement role to be that of decision maker within the context of site-based decision making?

6. In the identified role as decision maker, to what extent are the decisions related to matters of school curricula and/or instruction?

7. What overall factors do parents, principals, and teachers identify as enhancing or inhibiting the role of parent as decision maker within the context of site-based decision making?

8. What factors do parents, principals, and teachers specifically identify as enhancing or inhibiting the role of parent as decision maker as related to matters of school curricula and/or instruction within the context of site-based 
management? (p. 9)

The major findings of this study indicated that there was a need for teachers, parents, and administrators to better understand the parent's role in SBDM. Also, teachers and administrators felt that parental involvement was not integral to student achievement or decision making in the context of SBDM. In one school studied, the staff conveyed that they thought parents did not have enough training or experience with education to make decisions. This is consistent with traditional school beliefs that parents should not be involved in the decision making at the school.

Davies (1993) interviewed poor families in Boston, Liverpool, and Portugal to determine what encouraged and inhibited their involvement in their child's education. He also interviewed the teachers who taught their children at the elementary school level. Davies' exploratory study sought to answer the following questions

1. What are the extent and types of contacts between schools and families? Are these considered adequate by parents and teachers?

2. Are there particular groups of parents who are considered hard to reach of for whom the school-family relationship is seen to be problematic? What are their characteristics? Why are school-family relationships for these groups difficult?

3. How do low economic- or social-status parents assess the schools and the relationships between schools and families? Do they believe school is useful and important for their children? What do they see as the main purpose and benefits of schooling for their children?

The results of the 350 interviews were similar in many ways. Most parents 
reported that their contact with the school was mostly negative, with the schools only contacting the parents when the student was in academic or behavioral trouble. The educators reported that the parents were difficult to contact but the parents felt that was simply not true. The parents did admit that they did not enjoy going to the school because of negative experiences and therefore avoided it. The teachers' view of the parents was largely negative and full of stereotypes (i.e. parents were uneducated, criminals, had substance abuse issues, dirty homes, and were promiscuous). The parents, though, had a positive view of the schools, reporting that they were satisfied with the school and teachers.

Parents expressed an interest in being more involved in their child's education but did not know how to do this. There were differences between geographic locations in terms of supporting their child's education at home, with Boston parents reporting a high level of involvement with homework and other school-related activities and Portuguese parents reporting the least involvement at home.

Davies' research led him to develop The Schools Reaching Out Project. This project sought to improve parent-school relationships with the belief that improving these relationships will improve student achievement at two New York City schools. Part of this project included developing a school-community-planning council. This council encouraged the involvement of parents in the school decision making process. The intent of this council was to increase the level of parent responsibility in the school. Davies felt that parent involvement would assist in the goal of the success of all students, regardless of the socioeconomic status. It would also benefit parents by increasing their selfefficacy and motivation. This, in turn, benefits the schools as "parents who are involved 
have more positive views of the teacher and the school; and parents and others who participate are likely to be more supportive of the schools" (p. 206). Participation in the decision making process at the school level also leads to increased involvement in other organizations.

In 1989, Etheridge and Hall (1992) began a case study of Ms. Apple and her struggle to understand her role as decision maker on an SBDM council during the first three years of implementation. She served on the council and then became chairwoman. Ms. Apple understood the importance of her role as advocate for the other poor parents:

In order to tell the parents and make them understand, we have to use different language. Because [teachers] use a lot of educational terms, I will turn to a teacher and I ask, “now what does that mean?"...Parents don't know and they don't want anyone to know they don't understand. Parents are actually scared for someone to ask them some things because [parents] don't know what they are saying yes or no to. That is why in a lot of meetings or teachers' conferences, [parents] freeze up. [Parents] know the teacher has a higher education and is going to be speaking about things they know nothing about (p. 9).

At first she was intimidated by the position and not willing to speak her opinions. Through training she realized the potential of her role and began to let her concerns be known. During the first year Ms. Apple morphed from a timid parent to a vocal leader.

During the second year things began to change as the principal began to resent Ms. Apple's leadership. The principal rarely held meetings and if they were Ms. Apple was not notified. The following year her relationship with the principal improved and 
she continued to advocate for the parents and community members. She also advocated for the teachers, collaborating to save a teacher's position when enrollment went down. Ms. Apple used SBDM as a way to improve the climate and education of students and their parents:

SBDM is the best thing to come along for inner-city schools. If SBDM fails, [our] schools may close down. It is our only chance to have schools as good as those in the suburbs. Despite talk about equity, inner city schools don't have the same things as suburban schools, or the optional schools (p. 17).

Ms. Apple attributes her transformation from timid parent to parent advocate to her role as SBDM chairwoman.

During the 1994-95 and 1995-96 school years, Wanat (1999) performed a case study of the Basic School. Her research methods included both single and group interviews and observations. She interviewed one hundred and ten stakeholders (28 teachers, 21 certified staff, 12 classified staff members, 30 parents, and 19 community members). The school's basic belief was "It is simply impossible to have an island of excellence in a sea of community indifference, and when parents become school partners, the results can be consequential and enduring" (p. 323). Of the 565 students during the inaugural year, the majority were Native American, Asian, Hispanic, Caucasian, and African American.

The staff at the Basic School involves parents and community members in a variety of ways that were not traditional. The staff asks parents volunteer in classrooms to be involved in curricular issues. One parent stated 
The school is making opportunities available for people to feel they can come up with ideas, and they can work them into the curriculum. The ideas may be novel, but when a parent expresses an idea, things happen. This is different from my experience at other schools (p. 326).

Parents interviewed reported feeling welcome at the school and the teachers reported a genuine enjoyment of having parents involved. Parents were so welcome at the school that there was even a separate room in the building for parents. Parents also participated in the creation of the school, the opening of the school, and in decision making through involvement in the site-based council and committees. One parent referred to parents as a "cocreators of the school" (p. 331). Throughout her research, Wanat found that parents participated in the more traditional parental involvement roles such as classroom volunteer and chaperone, but took the opportunity to participate in more substantial roles such as decision maker whenever possible.

When Hargreaves (2000) studied educational change and teacher emotions he interviewed 53 teachers. He asked them about their negative emotions as related to incidents with parents. Negative emotions included anger toward parents who have unrealistic expectations, fear of parents who act erratically, annoyed with parents who question their professional judgment, and frustrated at parents they perceived not to care about their child's academics. Positive emotions occurred when parents were grateful, supportive, or agreed with them. The teachers did not want partnerships with parents where they learn from each other. This was particularly troubling since teachers often come from entirely different backgrounds and situations than their students and need the parents to teach them about "their students' lives, families and cultures, which shape their 
prior knowledge, frame what is important and motivating for them, and influence how they learn best" (p. 206).

\section{Minority Representation}

Kentucky Revised Statute 160.345(2)(b)(2) required that "School councils in schools having eight percent $(8 \%)$ or more minority students enrolled, as determined by the enrollment on the preceding October 1 , shall have at least one (1) minority member." If, after elections, there are no minorities represented on the council, the law requires the principal to oversee a special election for a minority parent and teacher representative. This is particularly important since educators are quick to pass judgment on minority parents, assuming that they "do not have the time, interest, money, or energy" (Kim, 2009, p. 87) to participate in schools.

James Comer (1987) conducted a longitudinal, qualitative study of an elementary school in New Haven, Connecticut. In this study, he hypothesized that "The application of social and behavioral science principles to every aspect of a school program will improve the climate of relationships among all involved and will facilitate significant academic and social growth of students" (p. 60). Comer found that parental involvement in school decision making was important for all parents, but particularly important to parents of low socio-economic and minority status. As their child's first teacher, their attitudes and beliefs pass on to their children. If parents feel empowered and valued then their children will feel empowered and valued.

Even though parental involvement in decision making can have a positive effect on student achievement, both teachers and administrators often oppose sharing power in 
any significant way because they had concerns that they would then lose this power. When parents chose to participate in the decision making process, it is not always successful. Often, parents serve on committees where they have little to no knowledge about the issue current at hand. They then are unable to contribute to the conversation, only contributing to the educator's belief that they are unwilling to participate. To avoid this, both teachers and administrators strive to use that parent's skills where they can be the most beneficial.

Twenty-five years later Comer (2005) revisited his research in New Haven and the increased success of the School Development Program. The program had expanded into over 1000 schools, the majority of which were low-income. Through his experiences in a variety of schools, Comer found that "if parents could be involved in ways that threatened neither the parents nor the teachers, parental involvement would reach a critical mass that could transform even the most dysfunctional school" (p. 39). The program developed a Parent Team where parents participate in developing a yearlong plan to build relationships and educate parents. These parents also participated in the planning of school activities designed to bring parents to the school for holiday celebrations. The program also relied on parent participation on the School Planning and Management Team, which afforded parents the opportunity to be involved in the school decision making process. The positive results from the schools that had adopted the School Development Program were increased parental involvement, a better understanding of the educational perspective, and increased parental confidence.

Chavkin and Williams (1993) distributed the Parent Involvement Questionnaire to families present at an open house. One thousand seven hundred and seventy nine Anglo 
parents completed the survey, 682 African-American parents, and 506 Hispanic parents. The Questionnaire was divided into several sections-attitudes about parental involvement, school decisions, parent-involvement roles, parent participation in activities, suggestions for improvement, demographic information, and information about decreased parental involvement at the high school level.

The researchers found that parents want to be involved, as indicated by over $95 \%$ of the participants, regardless of their ethnicity, stating that they either agree or strongly agree with the following statements:

- I should make sure that my children do their homework.

- I want to spend time helping my children get the best education.

- I cooperate with my children's teachers.

- Teachers should give me ideas about helping my children with homework.

- I should be responsible for getting more involved in my children's school.

- I want teachers to send more information home about classroom learning activities.(p.75)

The statements "I have little to do with my children's success in school" and "Working parents do not have time to be involved in school activities." (p. 75) received the least amount of support by parents.

Dissimilarities between the three ethnic groups occurred when asked if they agree with the statement "Teachers should be in charge of getting parents involved in the school," "School districts should make rules for involving parents," and "Working parents do not have time to be involved in school activities" (p. 76). Far more minority 
parents agreed with these statements than their Anglo counterparts.

All parent groups were interested in parent-involvement roles (paid school staff, program supporter, home tutor, audience, advocate, co-learner, and decision maker). Parents were the most interested in the traditional roles of audience and home tutor. When asked about their actual participation in school activities, the minority parents participated primarily in traditional activities. All parent groups indicated that there were few opportunities to participate in decision making.

From 1993 to 1997 Beck (1999) conducted a case study of Jackson Elementary in Los Angeles, California. Jackson serves approximately 1000 poor, immigrant students and was one of the first schools to participate in LEARN (Los Angeles Educational Alliance for Restructuring Now). Beck's research focused specifically on the parent involvement aspect of LEARN in this elementary school. Jackson encourages community involvement and had created a parent center on campus where parents can meet or take classes. In addition to the traditional parental involvement roles, the parents also participated in school governance and attended district meetings with the principal.

Although involved, the parents rarely spoke at the school or district meetings. When the parents did speak at school meetings it was to discuss non-instructional issues. When interviewed, though, they had very strong opinions. This led the researchers to believe that their silence at the meetings was not because they did not have an opinion. Educational jargon littered teacher conversation and parents sat silent any time teachers mentioned curriculum or instructional issues. The parents had an upmost respect for the educators and often submitted to them. There was a lack of trust among the parents who 
were illegal immigrants and feared they might be turned in by the school. Repeatedly during the interviews parents and teachers referred to the school community as a family. Indeed, it did become a family institution with faculty members involving their children in service projects at the school and actually enrolling their children in the school. This did not go unnoticed by the parents.

The parents are always told at meetings that they are important to the success of the school and the school staff stays true to this. There are regular parent meetings at the parent center and the administration makes every effort to attend the meetings to listen to the ideas and concerns of the parents. There are English language classes offered at the parent center because of a parent request.

The researchers concluded that there were factors other than the site-based management that led to the increased parental involvement in the school. Parents experienced an increase in confidence, though, from their involvement in the school. Beck and Murphy state, "We emerged from our investigation even more convinced than ever that the creation of structures to involve parents is, by itself, not enough to ensure their substantial involvement in their children's education" (p. 100).

\section{Decision Making}

While there are a handful of articles written specifically about SBDM and parental involvement in Kentucky (Bjork and Keedy, 2002; David, 2000; Gershberg and Shatkin, 2002; Holland, 2000; Lindle, 1994; Sexton, 2000), they are assertions and not empirical research studies. Only two empirical studies exist (Lindle, 1992b; Kannapel, Moore, Coe, and Aagaard, 1994), confirming Bjork and Keedy's (2002) assertion that 
"the role of parents on SBDM councils is important yet often overlooked in the reform literature" (p. 39). These empirical studies are over fifteen years old.

Lindle, Gale, and Curry-White (1996) analyzed the 1994 and 1995 SBDM surveys to determine perceived council effectiveness, involvement in decision making, and council activities. While most respondents rated their own council as effective in their own school (over $65 \%$ ), only $50 \%$ rated councils as effective throughout their district. Successful strategies for including parents were Open House meetings, scheduling council meetings at convenient times for the parents, and avoiding times that conflict with other community activities. Unfortunately, $80 \%$ of the principals surveyed failed to attempt any of these activities. Time remained the biggest barrier for all participants.

In terms of decision making, council members reported being involved in the consultation and selection of the principal. The council delegated discipline and curriculum issues to a committee, material and textbook selection to the faculty, and staff assignment and job classification to the principal. Rarely did parents participate in the budget process.

Kannapel, Moore, Coe, and Aagaard's (1994) broad study, School-Based Decision Making in Rural Kentucky Schools: Interim Findings of a Five-Year, Longitudinal Study, sought to answer the following questions:

- To what extent and in what manner is decision-making shared among the role groups involved in SBDM?

- In what way does the extent of shared decision-making affect educational reform 
in the schools?

- What factors facilitate or impede effective SBDM? (p. 1)

Their answers stemmed from over two years of field work in seven rural Kentucky schools. This field work included a qualitative analysis of interviews and observations. The study reveals the interim findings of a five-year study by the Appalachia Educational Laboratory.

Kannapel and her colleagues found that only one of the seven school councils practiced what she termed "balanced" decision making. In three of the other councils the teachers and principal dominated the decision-making and in the last three councils the principal made all of the decisions. This led to a decrease in parental involvement in the councils observed.

When questioned, many school personnel attributed the lack of parental involvement on councils to time constraints. Although this could be a factor, Kannapel et al. found evidence that schools may actually be discouraging parents from being involved in decision-making by not providing them with the necessary information about the meetings, decisions made at those meetings, and how to be involved in the decisionmaking process. One teacher shared her misgivings toward having parents involved in decision-making at the school level: "Some of our parents are sitting down there with...a high school education, and they come in and do volunteer work, and...they see things going on, but to understand the concepts...behind it, they don't" (p. 15). The teachers were not the only ones who expressed concern with parental involvement in school decision making - principals did, too. Two of the seven principals expressed their worry 
that the parents would have irrational demands coupled with ignorance about education. These principals were also quick to dismiss the subject of parental involvement at council meetings by stating that the school had already exhausted all possible methods to involve parents.

Although this study focused only on rural school councils, it is still a valid representation of the SBDM councils at the time. The geographic composition of the state of Kentucky is primarily rural. Primarily the large, urban school districts opted to wait until the 1995-1996 school year to implement SBDM and could not be part of the sample.

Adrian Blackledge (1995) interviewed parents, principals, and other education officials in Chicago for his study of parental involvement in the Chicago Public Schools and Britain. Through his research, he determined that parents needed be included in the process of decision-making and policy making in order to be more involved in their child's school. This was particularly important for English Language Learners, as educators may not fully understand their needs and the needs of the community. Often, these parents want to get involved but do not know how.

In his interview with Pam Tyson of Chicago Public Schools, Blackledge discovered that the Local School Councils helped to involve parents who might not usually get involved. Although initially met with resistance, teachers now had a positive attitude about parental involvement in decision-making. This is particularly true in the case of the perspectives that Hispanic and African American parents have to offer. Blackledge concluded, "What is quite clear is that Local School Councils have provided 
genuine empowerment opportunities for Hispanic families" (p. 7).

Cross and Reitzug (1996) summarized their observations of four elementary, one middle, and one high school in three midwestern school districts as they implemented site-based management. In each school, they discovered parents attending council meetings on a regular basis. Not only were parents attending the meetings, but they were involved in decision making in a variety of ways. One principal recalled

The proudest thing for me so far is that we have parents on our hiring committees... One parent was stunned that we were asking her to help us pick a teacher. She did an excellent job too... and went away with some sense of 'my kid is going to be in that teacher's room next year, and I helped hire her' (p. 16).

There were debates about the ratio of parents to teachers on one council. The teachers felt that they should represent the majority as they have the educational expertise, but the parents felt that they should represent the majority because they had the most invested in the school - their children. The council eventually determined that there should be equal representation as they all have a stake in the success of the school and its students.

Relationships between the parents, teachers, and administrators began to improve as a result of the council. Parents felt they were on equal footing with the principal and the more confident they felt, the more they began to speak at meetings. In most cases, council members focused on what was best for all children, not just what was best for their child or class. Teachers retained the belief that the principal was the primary decision maker, though. There were also conflicts with central office personnel, who did not want to relinquish control of the school budget and report cards. Based on their 
observations, the researchers recommended that schools make parent involvement real, challenge current relationships, let go of destructive relationships, build a climate of trust, and create meaningful staff involvement. One principal summed up the importance of site-based management when he stated, "Ultimately, the only way that city schools are going to stay alive is if somebody owns them" (p. 19).

Bauch and Goldring (1996) studied parental involvement and teacher decision making in Catholic schools, multi-focus magnet schools, and single focus public schools. They sought to answer the following research questions

1. Do parent involvement and decision making go hand in hand?

2. That is, are parents and teachers in schools of choice likely to work together as educational partners in assuring student success in school?

3. Or, in some types of schools, does either greater parent involvement or greater teacher decision making give one group an advantage in influencing decisions over the other? (p. 405)

To do this they collected surveys from teachers who taught $12^{\text {th }}$ grade classes and parents who had a child in $12^{\text {th }}$ grade. They selected Thirteen schools in Washington, D.C., Chicago, Illinois, and Chattanooga, Tennessee. To participate in the study, the schools had to meet the following criteria

(a) Serve a large population of minority or low-income students,

(b) Admit all or a portion of their students through choice and a formal application process, and

(c) Draw a large portion of students from inner-city areas. 
While all parents received surveys, the only surveys utilized in this study were those where the parents chose the school their child attended. The five Catholic schools had a $60 \%$ parent response rate $(n=265)$, the four single-focus public schools had a parent response rate of $52 \%(n=85)$, and the four multi-focus magnet schools had a parent response rate of $42 \%(n=311)$ for a total parent response rate of $56 \%(n=661)$. The Catholic schools had a teacher response rate of $52 \%(n=88)$, the single-focus public schools had $68 \%(n=72)$, and the multi-focus magnet schools had $36 \%(n=170)$ for a total teacher response rate of $51 \%(n=330)$.

The survey instrument used was a modified version of an instrument used in previous studies by the authors. The parent instrument used a 5-point Likert scale to measure the following five variables: traditional/passive parental involvement (eight items, $\alpha=.87$ ), parent participation in educational activities (four items, $\alpha=.69$ ), parent involvement in school decision making ( 13 items, $\alpha=.93$ ), parent communication with the school (four items, $\alpha=.73$ ), and their level of agreement with the statement "This school provides adequate opportunities for parents to be involved" (p. 415). The teacher instrument used a 5-point Likert scale to measure the following three variables: influence (five items, $\alpha=82$ ), seniority, and education.

Researchers used a canonical correlation to determine the relationships between the three types of schools and performed further canonical correlations within each type of school. Parents of students at the Catholic schools reported higher levels of parental involvement in participation in school activities and lower involvement in decision making and participation in their child's education. Teachers reported high influence in decision making. These teachers also reported high levels of seniority and education. 
Parents of students from the single-focus school reported low involvement in school activities and opportunities for involvement. Teachers reported low influence in decision making and lower educational levels, but high seniority. Parents of students from the multi-focus magnet schools reported high participation in school activities and low participation in their child's education. Teachers reported low influence in decision making and low seniority and educational attainment.

Din (1997) wanted to determine "what missions Kentucky rural school councils undertook, what benefits these schools had gained from implementing SBDM, and what problems these councils were facing" (p. 10). To do this he randomly surveyed 252 schools councils. Fifty-two percent responded $(\mathrm{n}=169)$ : 56 administrators, 69 teachers, 44 parents. Of the 56 administrators, five were from schools that did not have councils. Of the respondents, $64 \%$ said their council determined personnel issues, $66 \%$ selected the textbooks, $78 \%$ had the responsibility of selecting principals, $65 \%$ determined the school schedule, $74 \%$ made instructional policy, and $75 \%$ made the extra-curricular policy.

The study also determined that, although there was increased parental involvement, the principals were still the primary decision makers at the school level. What issue councils addressed and the types of decisions they made varied from council to council, but most of the them spent their time working on things other than instructional issues. Parental involvement remained an issue for many of the councils, with parents reporting that it was too time consuming. Additionally, the longer the council members served on the council, the more likely it was that the council was efficient. 
Throughout her work with the Prichard Committee for Academic Excellence, David (2000) studied school-based decision making. She compiled this information from her 1992-1995 studies along with interviews conducted between 1996-1999 in eight school districts in Kentucky. David found that SBDM worked as far as complying with the law but there are problems with the councils. Many are primarily run by the educators, specifically the principal, or individuals with hidden motives. One teacher summarized her concerns

My sense of councils is that most are not functioning as they were intended to function. The concept sounded real good, but it is not teacher-parent togetherness. Even teachers don't realize the power the council has in making a difference in the school—even in the school day. They don't lobby for their ideas (p. 210).

Despite the shortfalls of SBDM, there appears to be little interest in returning to the previous governance structure.

Parents who participate in SBDM report a more positive experience with the school and the programs they implement. One parent council member stated As a parent, if you just drop your kid off, you don't understand what goes on when they are here. When you are on the council and you start looking at what teachers do, you see what happens...I don't think parents realize how hard teachers work...I would recommend to anyone to be committees and [a site-based council]...I don't think the general public really realize what it takes to run the school financially and otherwise (p. 212). 
Participation on the council provided a way for members to understand a variety of perspectives. This also provided parents and teachers the opportunity to look at what is best for all students in the school, not just their child or the students in their class.

Johnson and Logan (2000) studied council members during the 1996-97 school year. They randomly selected two hundred and six school councils of the 1,100 in Kentucky. Of those selected, 124 were elementary, 34 were middle, and 48 were high schools. All council members were surveyed in addition to ten teachers and 5 parents who were not on the council but worked or had children at that same school. The survey instrument contained the School Council Efficacy Scale (SCES) and School Council Productivity Scale (SCPS). The researchers developed the SCES based on the 12question Teacher Efficacy Scale previously developed by Gibson and Dembo. The SCES supports the legal responsibilities of the school councils based on KRS 160.345. All scales utilized a 5-point Likert-type scale. The total response rate was $87 \%$ with only $70 \%$ usable.

Researchers conducted a one-way analysis of variance to determine if there was any variability by school level, setting, size, and the number of years the council had existed at the school. There were no differences $(p=.05)$. A Pearson $r$ determined that parent, teacher, and administrator efficacy and productivity scores independent of one another. The study compared the means within the five groups. The average mean for all groups was 3.94 with the range falling between 3.75 for parents who were not participants on the council to 4.15 for parents who did participate on the council. The researchers indicated that "these means suggest a moderately positive perception of council efficacy by all constituent groups" (p. 321). They conducted a similar analysis of 
the productivity scale. Results also indicated a "moderately positive perception."

They then analyzed the means and standard deviations for each group within the productivity scale. The item that was rated the highest by all groups was "council bylaws" while principals rated "assessing student progress" as the lowest. Teachers rated "assigning students to classes" and "programs within the school" lowest while parents indicated that "instructional" and "non-instructional staff time" were rated the lowest. They used a one-way ANOVA with the Scheffé test to compare the means in the efficacy scale $(F(4,676)=20.32, p<.001)$. This analysis revealed that council members' efficacy ratings were higher than non-council members. Among the council members, parents rated significantly higher than teachers or principals.

The study analyzed the productivity means in the same way $(F(2,429)=20.91$, $p<.001)$. The mean score for parents was significantly lower in the area of productivity than that of the teachers and principals. There was little difference in the means of the principals and teachers. All groups rated "council bylaws" the highest, there were few significant differences in the six items that dealt with student issues, but the similarities stop there with differences between at least two but more often all three of the groups. The items most often rated the lowest were concerned with instruction and student issues.

Schlinker, Kelley, O'Phelan, and Spall (2008) surveyed past council members ( $n=76)$ for their study Support and Resources for Site-Based Decision-Making Councils: Perceptions of Former Council Members of Two Large Kentucky School Districts. The survey had 29 Likert-type and open-ended questions. The sample was taken from two of the eight largest school districts in Kentucky. All participants had previously served on 
an SBDM council. The response rate was $58 \%$. The majority of the participants were female $(65 \%)$. Sixty-three percent were from the elementary schools, $22 \%$ from middle, and $14 \%$ from high. The majority $(89 \%)$ had served on the council for at least two years and $49 \%$ had served for longer.

At the elementary level, the previous council members reported that while on the council they focused on curriculum (63\%), assessment/accountability (58\%), decision making (52\%), budget (63\%), and personnel (60\%). At the middle and high school levels, respondents reported that they focused on curriculum (54\%), assessment/accountability (61\%), and decision making (57\%). This is contrary to previous studies.

The survey asked respondents about the level of support they had received. Sixtyfive percent rated their level of support as much or very much. Principal and teacher rated support the mid-sixties for helpfulness (much or very much). Parents rated support at $59 \%$ and community rated support at $35 \%$. High school respondents rated the support from central office at $82 \%$ while middle (41\%) and elementary $(63 \%)$ rated their support as much lower.

When respondents listed the strengths of the principal they mentioned strengths such as "organized, prepared, good listener, inclusive, informed, concerned for school issues, facilitative, and open to the ideas of others" (p. 36). The common theme of the weaknesses was that the decisions were already made even before the meeting. The respondents listed the strengths of the council as working well together and having a real concern for the students and the school. Weaknesses were that the council members were 
listeners only and not decision makers. When council members listed their strengths as a council member, they listed answers such as "listening, communicating well, clarifying ideas, and keeping the interests of the students as primary" (p. 37). Weaknesses listed mainly dealt with intimidation and not being vocal enough. Many also expressed a concern for a lack of knowledge about the law, curriculum, and assessment.

When asked about the perceived effectiveness of the SBDM council, $85 \%$ described the council as effective. This is contrasted by $45 \%$ of the respondents who reported that the council contributes to student achievement much or very much. All of the middle and high school respondents indicated that their test scores had increased since they were on the council but only $76 \%$ of the elementary school respondents agreed. Sixty-seven percent found that the council was useful, with parents indicating a higher agreement than teachers (86\%).

When asked about whether or not they found council membership beneficial, most respondents answered yes. One parent summarized many of the responses with the statement, "The council enables parents to get in-depth knowledge about the school's operations and needs" (p. 39). Teachers also indicated a newfound appreciation of the school operations. Both parents and teachers indicated that it provided them the opportunity to be more involved in education.

Johnson and Scollay (2001) examined "the amount of conflict, leader power, social influence, and their interrelationships within a vertical team" (p. 54), specifically, within an SDBM council. They distributed survey instruments to 206 SBDM Councils in Kentucky, collecting a $70 \%$ response rate. The survey instrument consisted of 
demographic variables, the Rahim Leader Power Inventory (RLPI), Rahim

Organizational Conflict Inventory I (ROCI-I), and Council Influence Scale (CIS). The results indicated that the amount of conflict, both interpersonal and intrapersonal, was moderate to low. The researchers determined that "the social influence of the council participants appear to be acceptable for functional school governance in most situations, and optimism may be justified over the workability of the vertical-team structure." (p. $60)$.

After decades of research on parental involvement in schools, Epstein et al. (2009) developed a framework to assist educators in building successful parental involvement programs in their schools. Within this framework the researcher listed six types of activities that led to increased parental involvement in schools: parenting, communicating, volunteering activities, learning at home, decision making, and collaborating with the community. Decision making activities afforded parents the opportunity to participate in the process of making decisions that affect their child directly. Epstein stated that this often included becoming a council member, member of a school improvement team, or participating in the Parent-Teacher-Association (PTA). The information gleaned from these experiences was important in providing parents the opportunity to participate in the improvement of the school. Epstein explained, "When parent representatives do their jobs well, they gather ideas from and return information to the families they represent" (p. 59).

Sheldon (2009) reviewed the existing literature on the connections between parental involvement and student outcomes. He found that high-quality and highperforming schools also exhibited strong relationships with parents and the community. 
High achieving students received strong academic support at home, regardless of their economic status. Schools with programs intentionally designed to improve parent and community relationships were more likely to have increased parental involvement. The type of parental involvement program affected the type of student achievement. Specific types of parental involvement programs can lead to increased student achievement in literacy, math, and science. It can also lead to increased attendance, improved behavior, and the successful transition to the next school level.

While there is extensive research that discusses the positive effects of parental involvement in schools, there is little research on parental involvement in school-based decision making. The bulk of the research focuses on the implementation process and is almost non-existent since 2003 .

\section{Public Education Leadership Project Research}

Some of the most recent research on school reform began in 2003 when 12 Harvard faculty members developed the Public Education Leadership Project (PELP) to assist urban school districts in the development and implementation of change. They found that urban schools in the United States were among the lowest when compared to similar countries and that the gap between minority and non-minority students continued to increase. Childress, Elmore, and Grossman (2006) document their work with PELP and the 15 large urban school districts they have been working with to improve student achievement. The majority of these districts lacked a district-wide strategy. The study found that implementing a reform strategy "requires building a coherent organization that enables people at all levels to implement their piece of the strategy" (p. 60). The 
researchers developed the PELP Coherence Framework to assist in developing and implementing these strategies. They explain that central to the Coherence Framework is the instructional core, a phrase used to "describe the critical teaching and learning that goes into the classroom" (p. 60). To strengthen the instructional core there must be an increase in teacher's skills, engage students, and strengthen the curriculum. To accomplish these goals the district should develop a focused strategy for achievement.

The researches cited their experiences with a variety of large urban school districts in various areas throughout the United States with declining test scores and large achievement gaps between minority and non-minority students. They cited their work with Chicago Public Schools and the improvements made since Arne Duncan became superintendent in 2001. Duncan created the strategy "to improve teaching and learning in classrooms systemwide and build the capacity of principals to lead change" (p. 62). In order to fulfill this strategy he appointed regional officers to assist principals in assisting teachers. He also implemented systems-based technology to measure student progress and assist teachers in developing strategies to get to the base of a student's educational issues. These systems also track educational objectives. Business service centers assisted principals in managerial tasks so they could focus on educational objectives. Duncan developed partnerships with local businesses to further utilize resources and developed documents that made it easier for parents to understand what was occurring in their child's school.

Childress, Elmore, Grossman, and King (2007) worked with the Public Education Leadership Project (PELP) at Harvard University. This group of researchers collaborated with other researchers to develop the PELP Coherence Framework. They began by 
defining coherence as "the elements of a school district work together in an integrated way to implement an articulated strategy" (p. 1). They hope this framework will assist districts, schools, and classrooms in working together to improve student achievement. A visualization of the Coherence Framework is in Figure 1.

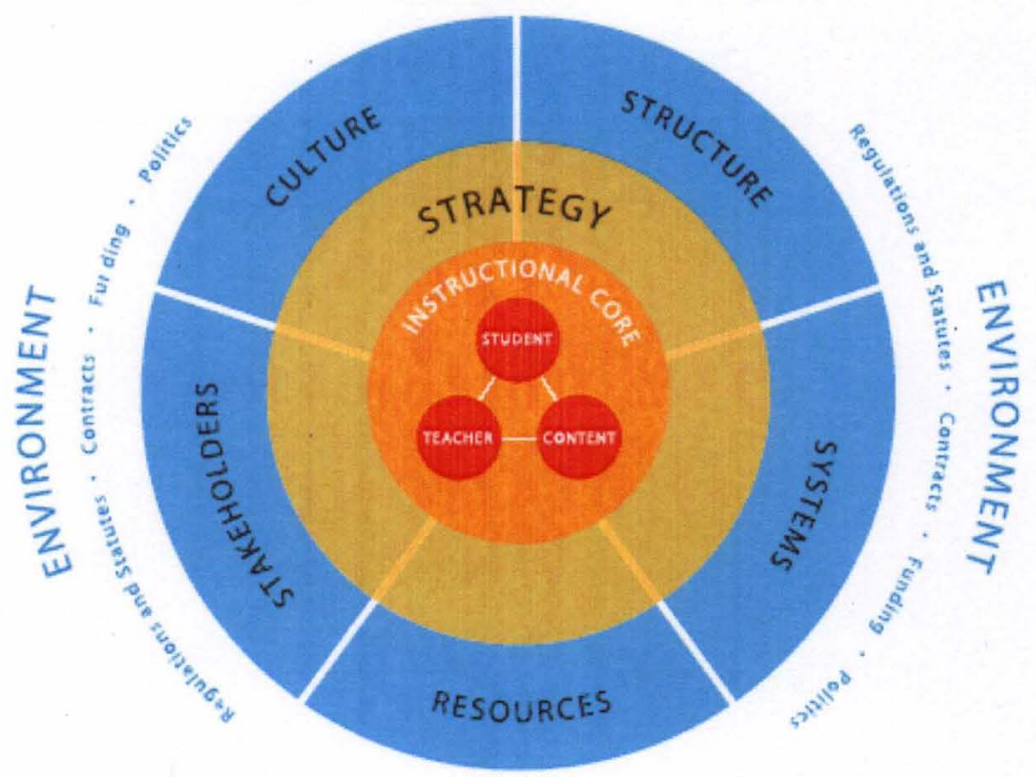

Figure 1. PELP coherence framework. From "Note on the PELP Coherence Framework" by S. Childress, R. Elmore, A.S. Grossman, \& C. King, 2007, Public Education Leadership Project at Harvard University.

According to the researchers, the center of the Coherence Framework is the student, teacher, and contents coming together to become the instructional core. Surrounding the instructional core is the strategy. The researchers defined this strategy as "the set of actions a district deliberately undertakes to strengthen the instructional core with the learning objective of raising student performance district-wide" (p. 3). They clarified that this strategy should vary according to the needs of each district and be 
intentional as to how the district plans to support instructional core. The PELP researchers did not recommend one particular strategy, but "assert that gaining coherence among actions at the district, school, and classroom levels will make a district's chosen strategy more scalable and sustainable" (p. 3). Surrounding the strategy were the organizational essentials of culture, structures and systems, resources, and stakeholders. District leadership influenced the success of these essentials. Surrounding all of this is the environment which included laws, contracts, budgets, and the political arena.

The PELP strategy suggested that the district create a mission statement with all students in mind. The researchers supplied an example of one such mission statement: "By 2012, $80 \%$ of students in the district will score in the proficient category or above on state reading and math tests, and there will be no gap between the performance of students of different ethnicities and/or socio-economic status" (p. 3). To do this the researchers suggested that districts break their goal into one, three, or five year goals. Monitoring these goals assisted the district in monitoring the progress toward these goals.

The researchers clarified that developing a theory of action could assist districts in connecting the district's strategy to its mission. An example of a theory of action was "The most direct way to increase student learning is to improve teachers' instructional practice. Therefore, if we help all teachers improve their instructional practice, then we will accomplish high levels of achievement for all students" (p. 4). Strategy is vital to the theory of action as the strategy links directly to the teachers, students, and curriculum. This strategy guides district leaders in their decision making. The district should then effectively communicate the strategy and actively support it. Since all schools are not the same, districts should differentiate according to the specific school's needs. The example 
provided is to increased autonomy for successful schools and decrease autonomy for those that struggle.

The PELP strategy recommended that districts carefully review the state of culture, structures, systems, resources, and stakeholders as they can affect the strategy implementation. Childress, Elmore, Grossman, and King defined culture as "the norms and behaviors in the organization; in other words, everyone's shared understanding of 'how things work around here"' (p. 6). Although culture is deeply ingrained in the organization, intentional actions on the part of the district could improve culture all the way to the school level. Structure, or "how the work of the district gets done" (p. 7), could be found in two forms--formal and informal. Organizational charts were an example of a formal structure. Informal structures were "the way decisions get made or the way people work and interact outside of formal channels" (p. 8). With these informal structures came power, which could be both a good and a bad thing for student achievement and structural changes. Careful choice of leadership on the part of the district could ensure that this informal structure does not hinder progress. Systems could also be formal or informal. Regardless of the formal or informal system, the "purpose of systems is to increase the district's efficiency and effectiveness in implementing strategy" (p. 8). These systems were in place to allow people to focus on the task at hand.

Resources included the people, the finances, and the technology necessary to implement the district's strategy. Stakeholders fell into six categories: district and school staff, governing bodies, unions and associations, parents and parent organizations, students, and civic and community leaders and organizations. Achieving support from all stakeholders was difficult but every effort, they explained, was be made to encourage the 
support of these stakeholders for the strategy. The district's environment included the laws, contracts, budgets, and political arena that surround the district. Although districts had very little control over their environments, they tried to increase support for the strategy and change the environment for the better.

\section{Self-Efficacy}

Bandura (1994) defines self-efficacy as "people's beliefs about their capabilities to produce designated levels of performance that exercise influence over events that affect their lives. Self-efficacy beliefs determine how people feel, think, motivate themselves and behave" (p. 2). Individuals with a strong sense of perceived self-efficacy set higher goals than those who do not and are more likely to be committed to those goals (Bandura, 1991; Bandura, 1998). Individuals with low self-efficacy envision scenarios where they do not succeed, thus promoting self-doubt, while those with high self-efficacy envision scenarios where they do succeed (Bandura, 1993). Perceived self-efficacy can affect an individual's performance, regardless of their skills and understanding. Even with similar skills and understanding the outcome can be poor, moderate, or great based on their perceived self-efficacy (Bandura, 1993). 


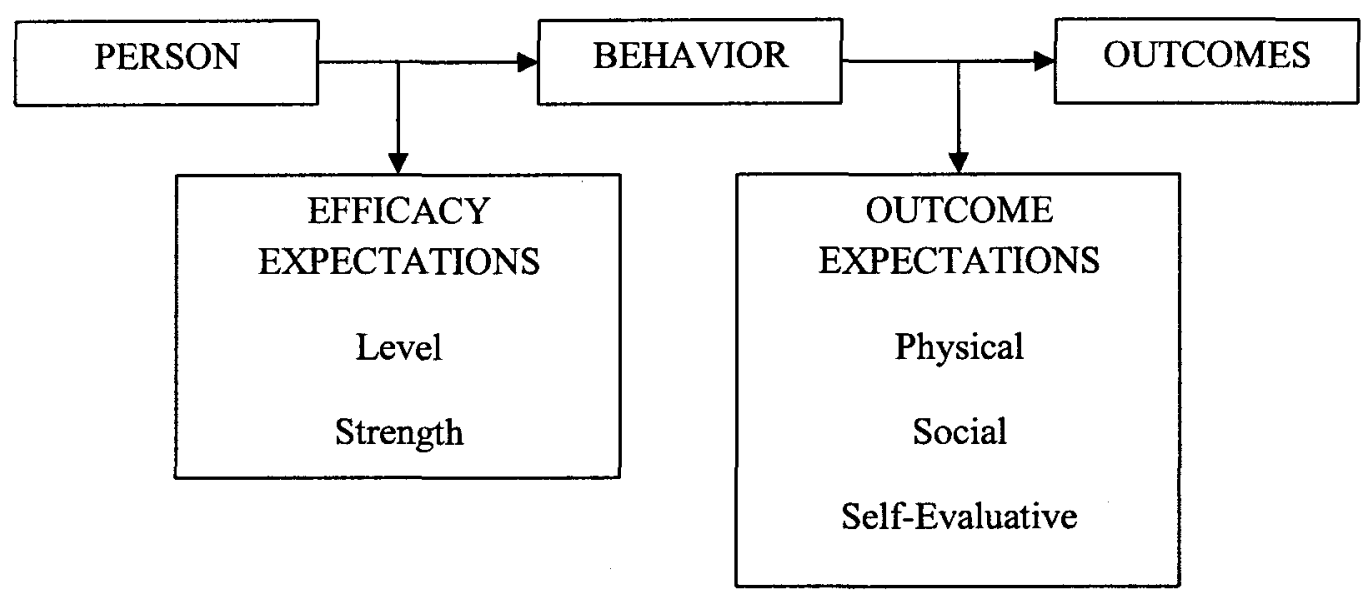

Figure 2. Diagrammic representation of the conditional relations between efficacy beliefs and outcome expectancies. From "Personal and collective efficacy in human adaptation and change," by A. Bandura, 1998, In J. G. Adair, \& K. L. Dion (Eds.), Advances in psychological science: Vol. 1. Personal, social and cultural aspects. Hove, UK: Psychology Press, p. 53.

Perceived self-efficacy not only affects the outcomes, but also affects the settings and situations in which an individual may choose to become involved (Bandura, 1977). People avoid settings and situations where they are uncomfortable or intimidated and choose settings and situations where they perceive themselves to be successful. Their efficacy expectations differ in terms of magnitude, generality, and strength. When a person with high perceived self-efficacy is met with obstacles, they exert great effort to eliminate them.

Mastery experiences, modeling, social persuasion, and physical and emotional states can alter perceived self-efficacy (Bandura, 1998). Efficacy increases as individuals 
participate in and master experiences but can decrease if they fail. Easy successes, though, can have a detrimental effect on self-efficacy as the individual then expects success and is disheartened when success is not easily achieved. Overcoming adversity through hard work and perseverance increases perceived self-efficacy. The success of others similar to oneself_-social modeling_-increases self-efficacy while seeing others one relates to fail decreases self-efficacy. Through social persuasion others increase an individual's self-efficacy by creating situations where they can be successful. Physical and emotional state also affects self-efficacy; a person who is in good physical condition and has a positive disposition is more likely to have increased self-efficacy.

Individuals with increased self-efficacy behave differently that those with diminished self-efficacy (Bandura, 1986; Bandura, 1993). They view challenges in a positive manner and are more likely to be involved in challenging activities. When they fail, they attribute this failure to insufficient effort on their part and are quick to try again. They exert control over potential stressors and threats in their lives. This results in increased accomplishments with reduced stress and potential for depression. Those individuals with decreased self-efficacy doubt themselves, have less commitment to their goals, and are less likely to participate in complex tasks. If they fail, they blame themselves and this reduces their motivation. They recover slowly from failure and often suffer from increased stress or depression.

Perceived self-efficacy affects motivation and goal-setting. Those with increased self-efficacy set goals, anticipate outcomes, and remain strongly committed to their goals (Bandura, 1989; Bandura, 1993). The stronger their self-efficacy is, the stronger their commitment to the realization of their goals. The opposite is true for those with low self- 
efficacy. When met with the potential for failure, they decrease their effort and commitment, thus sabotaging their own goals. This then decreases their perceived selfefficacy even more.

Individuals do not live their lives in a vacuum and often work together to achieve desired goals. Just as those with high self-efficacy are more likely to take on more complex tasks, so are groups with high collective efficacy. According to Bandura (1998), this collective efficacy influences

the type of futures they seek to achieve; how well they use their resources; how much effort they put into their group endeavor; their staying power when collective efforts fail to produce quick results or meet forcible opposition; and their vulnerability to discouragement (p. 65).

High efficacy—either collective or individual-contributes to the success of the group. Those with low self-efficacy tend to bring doubt and lack of directionality to the group.

Just as increased self-efficacy enhances the success of the collective group, parents' increased self efficacy can increase the academic achievement of their children (Bandura, 1998). If parents exercise a high belief that they can support their child's education then they increase their child's efficacy. This increased self-efficacy on the part of the child then positively affects their intellectual attainment and their social and emotional health. If parents exercise the belief that they cannot support their child's education then this belief transfers to the child and negatively affects that child's achievement.

Goddard, Hoy and Hoy (2004) synthesized the collective efficacy beliefs of 
teachers as they related to student achievement. They explained that perceived collective efficacy "refers to the judgment of teachers in a school that the faculty as a whole can organize and execute the courses of action required to have a positive effect on students" (p. 4). The researchers echoed Bandura's belief that there are four sources that form efficacy-mastery experiences, vicarious experiences, social persuasion, and affective states. Teachers experienced mastery through previous successful experiences in the school setting. Successful experiences increased their belief in the school staff while unsuccessful experiences decreased their collective efficacy. Too many easy successes, though, would lead to dissuasion. Vicarious experiences, or those experiences modeled by someone other than the individual, also happen to school faculties. Collective efficacy increases by watching other similar groups succeed or decreases by watching them fail. Goddard, Hoy and Hoy stated that social persuasion could be "encouragement or specific performance feedback from a supervisor or colleague or it may involve discussions in the teachers' lounge, community, or media about the ability of teachers to influence students" (p. 6). This social persuasion can increase collective efficacy. The affective states of anxiety or excitement also affect perceived collective efficacy. Organizations with high perceived collective efficacy deal better with high pressure situations, such as decreased student achievement on high-stakes tests, while those with decreased collective efficacy are not well equipped to deal with the results.

The researchers stated that the increased interest in collective efficacy at the school level could be due to the "probable link between collective efficacy beliefs and group goal attainment" (p. 7). This was shown to have an effect on student achievement because "a robust sense of group capability establishes (cultural norms) for success that 
encourages organizational members to work resiliently toward desired ends" (p. 8).

These high expectations on the part of the group engrained themselves into the culture and become the norm. The researchers found that one way to increase collective efficacy was to involve stakeholders in the decision making process. Lack of participation in decision making led to reduced collective efficacy and a feeling of reduced control over the situation.

\section{Decision Making Framework}

Daniel Stufflebeam (1971) developed the CIPP Evaluation Model as a "means to systematically provide timely evaluative information for use in decision making" (p. 1). The acronym represents context, input, process, and product evaluation. Included in the evaluation process was delineation of questions, obtaining information, and providing information. Table 3 provides a visual of the relationship within the evaluation process. In the case of context evaluation, delineation entails reviewing and/or developing the goals to be obtained and the planning process. Obtaining includes a needs assessment, review of any underutilized opportunities, and the exploration of any problems. Proving entails an evaluation of all decisions made. For input evaluation, delineation entails moving objectives to strategies. Providing involves reports to the decision makers about the strategies. Process evaluation supplies information about the progress during the initial implementation period. Delineation involves the identification of any barriers. Obtaining is the day-to-day monitoring of the project. Providing is the regular report to the project managers. In project evaluation, delineation involves a further look into the objectives, with close attention to the problems to be solved. Obtaining involves for 
formative and summative assessment of the objectives. This leads to providing evaluation reports.

\begin{tabular}{|c|l|l|l|l|}
\hline & \multicolumn{1}{|c|}{ CONTEXT } & \multicolumn{1}{|c|}{ INPUT } & PROCESS & PRODUCT \\
\hline DELINEATE & $\begin{array}{l}\text { System } \\
\text { variables and } \\
\text { values }\end{array}$ & $\begin{array}{l}\text { Problem } \\
\text { specifications } \\
\text { Design criteria } \\
\text { Constraints }\end{array}$ & $\begin{array}{l}\text { Process } \\
\text { decision points } \\
\text { Milestones } \\
\text { Barriers }\end{array}$ & $\begin{array}{l}\text { Effectiveness } \\
\text { criteria }\end{array}$ \\
\hline OBTAIN & $\begin{array}{l}\text { Performance } \\
\text { and judgment } \\
\text { data }\end{array}$ & $\begin{array}{l}\text { Identification } \\
\text { and analysis of } \\
\text { strategies }\end{array}$ & $\begin{array}{l}\text { Monitoring of } \\
\text { procedures }\end{array}$ & $\begin{array}{l}\text { Primary, } \\
\text { secondary, and } \\
\text { tertiary effects }\end{array}$ \\
\hline PROVIDE & $\begin{array}{l}\text { Profile of } \\
\text { needs, } \\
\text { opportunities } \\
\text { and problems }\end{array}$ & $\begin{array}{l}\text { Strategies by } \\
\text { problems } \\
\text { matrix }\end{array}$ & $\begin{array}{l}\text { Progress reports } \\
\text { Exception } \\
\text { reports }\end{array}$ & $\begin{array}{l}\text { Description and } \\
\text { explanation of } \\
\text { project } \\
\text { attainment and } \\
\text { impact }\end{array}$ \\
\hline
\end{tabular}

Figure 3: Operational definitions for the four types of evaluation. From "The relevance of the CIPP evaluation model for educational accountability" by D.L. Stufflebeam, 1971, Retrieved from ERIC database (ED 062385), p. 29.

\section{Conclusion}

Pankratz and Petrosko (2000) stated, "Organized citizen and business groups can help sustain reform and counter attempts by opponents who want to weaken or sabotage changes" (p. 278). In order for the reform efforts in Kentucky to be successful, parents and community members must support and take ownership of them. Parents view themselves as partners in education when they have a leadership role in the decisionmaking process. When parents have a voice in the decision-making process they are more likely to support the school and their child's education. SBDM councils provide all 
stakeholders, including parents, with a vehicle to discuss their concerns and better increase their understanding of how decisions are made at the school level. This ownership manifests itself in increased participation for all parents in the academic endeavors of their children, thus increasing their child's academic performance.

This study examined the perceptions of Kentucky SBDM council members regarding the productivity and efficacy of the councils. This included the relationships between the council member positions, council member demographic variables, perceived efficacy, and perceived productivity. It replicated previous research on the efficacy and productivity of SBDM councils in Kentucky to determine which, if any, demographic characteristics determined the degree that school stakeholders consider councils to have efficacy and be productive and whether or not the various constituencies differed in these perceptions. The study expanded previous research to determine if perceived efficacy and/or productivity could be predicted by various demographic characteristics. Finally, the study explored the amount of variance in perceived efficacy and productivity between and within individual schools for the SBDM council parent and teacher positions. 


\section{CHAPTER III}

\section{METHODOLOGY}

The purpose of this study was to examine the perceptions of Kentucky SBDM council members concerning the productivity and efficacy of the councils. The major variables studied were council member position, council member demographic characteristics, perceived efficacy, and perceived productivity.

The research data came from an already completed field survey. This study used the methods of descriptive analysis, causal-comparative analysis, and correlational/predictive research. Statistical procedures included calculation of means and standard deviations, as well as multivariate analysis of variance (MANOVA), ordinary least squares multiple regression, and random effects analysis of variance (ANOVA).

\section{Research Advancements}

Johnson and Logan (2000) examined "the perceptions of school stakeholders regarding the efficacy and productivity of SBDM councils in Kentucky" (p. 316). They questioned: “(1) To what degree do school stakeholders consider school councils to be effective and productive? and (2) Do the various constituencies differ in their perceptions 
of the council efficacy and productivity? Are there differences between constituents serving on councils and those not on councils?'(p. 317). Johnson and Logan distributed surveys to a random sample of both council and non-council members during the 19961997 school year. Over a decade later, this study built on the research of Johnson and Logan. The study determined how Kentucky SBDM council members perceived the productivity and efficacy of the councils and explored variables measured on council members.

\section{Participants and Data Collection Procedures}

The possible study participants were administrators $(n=135)$, parents $(n=315)$, and teachers/staff $(n=525)$ who were members of School-Based Decision Making councils $(N=975)$ in elementary $(n=89)$, middle $(n=22)$, and high $(n=21)$ schools in Jefferson County Public Schools in Louisville, Kentucky. Although three special schools were included in the original survey sample, they were excluded from the study. All members of the SBDM council during the 2009-10 school year received the survey. The SBDM council chairperson received the survey via the interoffice mail delivery system. A letter enclosed with the survey instructed the SBDM chairperson (See Appendix C) to distribute them to council members during the next scheduled SBDM meeting. At that meeting council members had the opportunity to complete the survey. The researcher received the completed surveys via the interoffice mail delivery system. The participants self-reported demographic characteristics, completed the School Council Efficacy Scale (SCES) and School Council Productivity Scale (SCPS), as well as other items unrelated to this research. This process was consistent with the distribution of past survey instruments to SBDM council members since 1996. 


\section{Instrument}

The survey instruments (See Appendix C) assessed SBDM council efficacy and productivity. The first section of the instrument required the participant to self-report the following demographic characteristics: (a) SBDM council position (parent, principal, teacher/staff); (b) ethnicity (African-American, White, Latino, Other); (c) gender (male, female); (d) age group (under 26, 26-34, 35-49, 50-64, 65+); (e) level of education (some high school, high school diploma, some college, college diploma); and (f) years on the council (less than 1, 1-2, 3-5, 6+). The potential answers to the demographic items about ethnicity, age group, and level of education on the JCPS protocol used in the Comprehensive School Survey structure. This permitted other researchers to compare the demographics of the council members with those of the district at large. Additional questions in this section included: (a) "The overall effect the SBDM council has had on student achievement (none, low, average, high)," and (b) "Please indicate the average number of times per year the SBDM council reviews Kentucky Core Content Test (KCCT) data $(1,2,3,4,5+)$." These were in this section in an effort to keep the survey instrument from exceeding the two page minimum used in the SBDM Surveys since 1996.

The second section of the research instrument reflected the legally-required policies outlines in KRS 160.345 and Johnson and Logan's (2000) School Council Productivity Scale (SCPS). The specific names of the policies came from the Kentucky Association of School Council's Policy Handbook (2008) in an effort to stay consistent with the language used throughout Kentucky. Council members indicated the extent to which SBDM Policies affected student achievement. 
The third section of the research instrument provided participants with a list of eight parental involvement activities and requests that the participants rate them on a 5point scale ( $1=$ never, 5 = frequently) based on the statement, "Our SBDM council actively encourages ALL parents to be involved through:." This section will not be used in this research.

In the fourth section participants responded to two items which relate to decision making: "I am given relevant information needed to make informed decisions" (never, sometimes, usually, high) and "Most decisions of the council are determined by the following role group" (parents, teachers/staff, principal, all members). There were two additional items on the use of Committees and training: "Our council's use of Committees is best described as:" (never, sometimes, usually, always) and "Training activities of the council have been relevant" (never, occasionally, usually, always). These last two items, while useful in driving the planning process at the district level, will not be used in this research.

The final section contained the School Council Efficacy Scale (SCES) developed by Johnson and Logan (2000). Participants responded using a 4-point Likert-style scale ( 1 = strongly disagree, 2 = disagree, $3=$ agree, $4=$ strongly agree $)$. SPSS used reverse coding with seven items. Item 12 in the original SCES was the statement, "The council can't do much because the council members don't have enough information about each problem." The writers modified this item to remove the double negative. The item became, "The council is unable to make decisions because the council members have inadequate information about each problem." 
The instrument contained several preprinted items. These included the school name, school level, and level of efficiency. The level of efficiency is an annual review based on a rubric developed by the JCPS Office of SBDM. The councils received a score between one and four $(1=$ does not meet any legal requirements; $2=$ working toward meeting the legal requirements; $3=$ meets all legal requirements; $4=$ working beyond the legal requirements) based on factors such as bylaws and policies and whether or not have they been adopted/updated, are council and Committee minutes present, are all role group positions represented, have all council members completed or updated their training, and does the council meet regularly with a quorum.

\section{Validity and Reliability}

A pilot study involved six principals, 28 teachers/staff members, and 8 parents from the same school district field tested the survey instrument. The participants were all council members during the 2007-08 and 2008-09 school year, but were not on the council during the 2009-10 school year when the study was performed. Since the law dictates that the principal is on the council, the previous principals who participated in the pilot study were either retired or had moved into other positions other than principal. The researcher used stratified sampling to ensure that the sample would reflect the higher number of elementary schools $(n=89)$ than middle, $(n=22)$ high $(n=21)$, and special $(n$ $=3$ ), thus accurately representing those who will participate in the research project.

For the data obtained from study participants, the researcher performed a reliability analysis on the two scales measuring efficacy and productivity. The goal for each scale was to obtain a Cronbach alpha internal consistency reliability score of .70 or 
greater. If necessary, the researcher deleted items from each scale that did not meet this criterion.

As previously determined by Johnson and Logan (2000), "The scale has content validity because the items were taken directly from the list of responsibilities charged to the school councils by the KERA legislation" (p. 319). The language used in the SCPS was taken directly from the Kentucky Association of School Council's list of policies required by the Kentucky statute and reflects the changes in the statute over the past 15 years.

\section{Data Collection}

The SBDM survey was an annual survey and the process of notification was similar to that used in the past. Pre-notice letters sent through district email to the SBDM council chairperson to inform them that the surveys would soon be delivered via the interoffice mail delivery system (See Appendix B). The surveys contained a cover letter with specific instructions for the chairperson (See Appendix C). One week before survey deadline the council chairperson received a reminder letter (See Appendix E). The chairperson returned completed surveys via the interoffice mail delivery system. The study received the approval from the University of Louisville's Human Subjects Protection Program.

\section{Statistical Analysis}

Statistical analysis for this study consisted of descriptive and inferential statistical procedures that are appropriate for each research question. The statistical procedures conducted are as follows. 
Research Question 1 Descriptive statistics (e.g. means and standard deviations) were employed to determine the degree that schools stakeholders consider school councils to have efficacy and to be productive.

Research Question 2 A multivariate analysis of variance (MANOVA) was used to determine whether or not the various constituencies differ in their perceptions of the council efficacy and productivity.

Research Questions 3 and 4 Multiple regression assisted in the determination of how much variance in the average efficacy score could be predicted by the following independent variables: (a) age, (b) number of years served on council, (c) gender, (d) ethnicity, (e) SBDM council position (principal, teacher, or parent), (f) perception of receiving relevant information for decision-making, (g) use of committees, (h) perception of relevance of training activities, (i) school level, and (j) level of efficiency score. The same process was conducted substituting the productivity score as the dependent variable.

Research Questions 5 and 6 A random effects analysis of variance (ANOVA) was employed to determine the amount of variance in the average efficacy score within schools and between schools for the SBDM council positions teacher and parent. This same process was conducted substituting the productivity score as the dependent variable.

\section{Limitations}

Major limitations of this study were that the demographic variables in Jefferson County Public Schools (JCPS) are very different than other districts in the state. JCPS is located in the largest urban area in Kentucky. With few exceptions, the rest of the school districts in the state serve students from rural areas; therefore, the results of this research 
study are most appropriately generalized to urban or suburban locations rather than rural regions. 


\section{CHAPTER IV}

\section{RESULTS}

This chapter presents results of the data analyses that the researcher performed to address the research questions. First, there is an explanation of the participants and the data collection process. Then the researcher presents descriptive statistics on demographic variables measured on participants. Finally, separate sections are presented that contain the analyses for the research questions.

\section{Participants and Data Collection}

The Jefferson County Public Schools Office of SBDM collected survey data during March and April of 2010. The study participants were administrators $(n=105)$, parents $(n=196)$, and teachers/staff $(n=395)$ who were members of SBDM councils $(N$ $=707$ ). Eleven participants elected not to report their position on the council. The overall percentages (principals $15.1 \%$, parents $28.2 \%$, and teachers $55.9 \%$ ) accurately reflected the standard composition of the councils (principals $16.6 \%$, parents $33.3 \%$, and teachers $50 \%$ ).

The percentages of respondents represented each level of schooling: elementary $58 \%$, middle $19.8 \%$, and high $22.2 \%$. The percentage of respondents from the elementary level was lower than the composition of schools in Jefferson County that have 
SBDM councils (elementary 68\%). The percentages for middle and high schools were somewhat higher than the district's percentages (middle 16.6\%, and high school $15.9 \%$ ). Although three special schools were included in the original survey sample, they were excluded from the study. All members of the SBDM council during the 2009-10 school year received the survey. The SBDM council chairperson received the survey via the interoffice mail delivery system. A letter enclosed with the survey instructed the SBDM chairperson (See Appendix C) to distribute them to council members during the next scheduled SBDM meeting. At that meeting, council members had the opportunity to complete the survey. The researcher received the completed surveys via the interoffice mail delivery system. The participants self-reported demographic characteristics, completed the School Council Efficacy Scale (SCES) and School Council Productivity Scale (SCPS), as well as other items unrelated to this research. This process was consistent with the distribution of past survey instruments to SBDM council members since 1996.

\section{Descriptive Statistics on Demographic Variables}

Table 2 shows frequency distributions for demographic variables measured on the participants. Of the participants, $58 \%$ served on councils in elementary schools, $19.8 \%$ in middle schools, and $22.2 \%$ in high schools. As outlined in KRS 160.345, members on the council were parents, teachers, or principals. Most respondents (55.9\%) were teachers or staff. About $75 \%$ of the respondents were white and slightly more than $20 \%$ were African American. These ethnic groups predominated. Over $70 \%$ of respondents were female. Almost all the respondents were in age range between 26 and 64 , with the majority between 35 to 49 years of age. Over $90 \%$ of participants had either 
some college or had a college degree. The majority of participants were on a council two years or less (29.3\% less than a year and $32.4 \%$ one to two years).

Table 2

Frequency Distributions for Demographic Variables $(N=707)$

$\begin{array}{lll}\text { Variable } & \mathrm{n} & \%\end{array}$

School Level

Elementary

Middle

410

58.00

High

140

19.80

157

22.20

Position

Parent

Teacher/Staff

196

27.70

Principal

396

55.90

Missing data

105

14.90

$11 \quad 1.60$

Ethnicity

African American

151

528

White

6

Other

Missing data

$14 \quad 2.00$

$8 \quad 1.10$

Gender

Female

511

72.30

Male

176

24.90

Missing data

$20 \quad 2.80$

Age
$\begin{aligned} & \text { Under } 26 \\ & 26-34 \\ & 35-49 \\ & 50-64 \\ & 65+ \\ & \text { Missing data }\end{aligned}$

19

2.70

152

359

21.50

164

50.80

8

23.20

5

1.10

.70 
Table 2 (continued)

\begin{tabular}{lrr}
\hline Variable & $\mathrm{n}$ & $\%$ \\
\hline Education & & \\
High school diploma & 21 & 3.00 \\
Some college & 47 & 6.60 \\
College diploma & 623 & 88.10 \\
Missing data & 16 & 2.30 \\
& & \\
Years on council & & \\
Less than 1 & 207 & 29.30 \\
1-2 & 229 & 32.40 \\
3-5 & 160 & 22.60 \\
6+ & 107 & 15.10 \\
Missing data & 4 & .60 \\
\hline
\end{tabular}

\section{Analysis for Research Question 1}

The first research question was this: "To what degree do school stakeholders consider school councils to have efficacy and to be productive?" The School Council Productivity Scale (SCPS) measured the productivity perceptions of council members. The instrument asked participants to indicate the extent to which SBDM policies have affected student achievement ( $1=$ none, $2=$ low, $3=$ average, $4=$ high $)$. Table 3 presents descriptive statistics on the 14 SCPS items. For the SCPS, the Cronbach alpha internal consistency reliability coefficient was .93 , exceeding the suggested minimum of .70 (Nunnally \& Bernstein, 1994). 
Table 3

Descriptive Statistics for Items on the School Council Productivity Scale (SCPS)

$(N=620)$

\begin{tabular}{llll}
\hline Item & Variable & Mean & $S D$
\end{tabular}

\begin{tabular}{|c|c|c|c|}
\hline $10 \mathrm{a}$ & Alignment with State Standards & 3.63 & .61 \\
\hline $10 \mathrm{~b}$ & Committee & 3.51 & .63 \\
\hline \multirow[t]{2}{*}{$10 \mathrm{c}$} & Consultation with Principal & & \\
\hline & for Hiring & 3.63 & .61 \\
\hline $10 \mathrm{~d}$ & Curriculum & 3.64 & .57 \\
\hline \multirow[t]{2}{*}{$10 \mathrm{e}$} & Discipline \& Classroom & & \\
\hline & Management \& Safety & 3.55 & .60 \\
\hline $10 f$ & Enhancing Student Achievement & 3.64 & .58 \\
\hline $10 \mathrm{~g}$ & Extracurricular Programs & 3.40 & .66 \\
\hline $10 \mathrm{~h}$ & Instructional Practices & 3.55 & .62 \\
\hline \multirow[t]{2}{*}{$10 \mathrm{i}$} & Instructional \& Non-Instructional & & \\
\hline & Staff Time Assignment & 3.39 & .68 \\
\hline $10 \mathrm{j}$ & Program Appraisal & 3.40 & .65 \\
\hline $10 \mathrm{k}$ & School Day \& Week Schedule & 3.30 & .74 \\
\hline 101 & School Space Use & 3.34 & .68 \\
\hline $10 \mathrm{~m}$ & Student Assignment & 3.30 & .76 \\
\hline $10 \mathrm{n}$ & Technology Use & 3.52 & .65 \\
\hline \multicolumn{2}{|c|}{ Productivity Scale Mean } & 3.48 & .48 \\
\hline
\end{tabular}


The School Council Efficacy Scale (SCES) measured the efficacy perceptions of council members. Participants responded to statements about the council efficacy ( $1=$ Strongly Disagree, $2=$ Disagree, $3=$ Agree, $4=$ Strongly Agree). Table 4 presents descriptive statistics on the 12 SCES items. For the SCES, the Cronbach alpha internal consistency reliability coefficient was .89 , exceeding the suggested minimum of .70 (Nunnally \& Bernstein, 1994). Items $16 \mathrm{~b}, 16 \mathrm{~d}, 16 \mathrm{~h}, 16 \mathrm{i}, 16 \mathrm{j}, 16 \mathrm{k}$, and $16 \mathrm{i}$ were reverse coded. This was done so that, for the overall scale, a higher score would indicate higher perceived efficacy. 
Table 4

Descriptive Statistics for Items on the School Council Efficacy Scale (SCES)

$(N=639)$

Item Variable Mean $\quad S D$

16a When a council makes plans, I am

certain that the council can make

them work.

$16 \mathrm{~b}(\mathrm{R}) \quad$ When the council makes plans, it rarely

completes them.

16c The council finishes all tasks that

it undertakes.

16d (R) The council avoids dealing with difficult problems.

16e The council handles difficult

problems well.

16f The council is secure in its ability to

make a difference in the school.

$3.47 \quad .60$

$16 \mathrm{~g}$ The council handles unexpected

problems well.

16h (R) The council seems incapable of dealing with most problems that come up in the school.

16i (R) The council has no way to ensure that decisions will be implemented. 
Table 4 (continued)

Item Variable Mean SD

16j (R) The council delays addressing difficult problems.

16k (R) The council's decisions are ignored by the school administration.

$161(\mathrm{R}) \quad$ The council is unable to make decisions because the council members have inadequate information about each problem.

Note. The letter R next to the item number indicated it was reverse coded.

Overall, council members had a positive perception of the productivity and efficacy of the councils. The mean for productivity was 3.48 , indicating that participants perceived SBDM policies to affect student achievement between an average and high level. The mean for efficacy was 3.47. Since the closer the response to four, the higher the efficacy, this indicates that council members were between agree to strongly agree that the council had efficacy.

\section{Analysis for Research Question 2}

Research Question 2 was the following: "Do the various constituencies differ in their perceptions of the council efficacy and productivity?" The researcher conducted a 
multivariate analysis of variance (MANOVA). The independent variable had three levels corresponding to the council positions of: (a) parent, (b) principal, and (c) teacher/staff. The two dependent variables were the mean scores on the scales measuring productivity and efficacy (i.e., mean SCPS score and mean SCES score).

Table 5 shows descriptive statistics for the analysis. Box's test for equality of covariance matrices revealed a significant difference in variability between the groups, $F(6,902077)=8.49, p<.001$. Thus, the results did not meet the equality of variancescovariances assumption of MANOVA. The MANOVA testing mean differences was statistically significant, Wilks' lambda $=.978, F(8,1352)=3.78, p<.05$. The researcher performed multivariate pairwise comparisons (Hotelling's T square statistic), using .05 as the level of significance for each test. There was a difference between the parent and the teacher/staff groups, $F(2,676)=7.16, p<.01$.

The researcher performed Bonferroni pairwise multiple comparisons on each dependent variable. Each of these contrasted the parent group with the teacher/staff group. A difference was found on the efficacy scale mean. The parent group had a higher mean on efficacy $(M=3.54)$ than the mean of the teacher/staff group $(M=3.43)$. The researcher calculated a measure of effect size, Cohen's $d$ statistic, with these data. For these means, $d$ equals .26, indicating a small effect size (Hinkle, Wiersma, \& Jurs, 2003). 
Table 5

Descriptive Statistics on Groups Used in MANOVA for Research Question 2

\begin{tabular}{lllll}
\hline & Position & Mean & SD & N \\
& & & & \\
\hline Productivity scale mean & Parent & 3.45 & .49 & 191 \\
& Principal & 3.46 & .56 & 102 \\
& Teacher/Staff & 3.50 & .45 & 387 \\
& Total & 3.48 & .48 & 680 \\
& & & & \\
Efficacy scale mean & Parent & 3.54 & .39 & 191 \\
& Principal & 3.49 & .46 & 102 \\
& Teacher/Staff & 3.43 & .47 & 387 \\
& Total & 3.47 & .45 & 680 \\
& & & & \\
\hline
\end{tabular}

Because Box test of the equality of variances and covariances was significant, there was some chance of bias in the results. As a check on the results, the researcher performed an additional analysis. The researcher found one significant difference (efficacy means for parents vs. teachers/staff) and analyzed the data using the Tamhane $\mathrm{T} 2$ test of multiple comparisons, this works with data having heterogeneous variances (Gamst, Myers, \& Guarino, 2008). The means were statistically significant $(p<.02)$, indicating that it is unlikely the difference between the groups was a chance difference. In summary, there were no differences between parents and principals on average ratings of productivity and efficacy. Neither was there a difference between principals and teachers/staff. The one difference that was found showed that parents had a higher rating for efficacy than teachers/staff. The difference was statistically significant, but small in magnitude. 


\section{Analysis for Research Question 3}

Research question 3 was the following: How much variance in the average efficacy score can be predicted by the following independent variables: (a) age, (b) number of years served on council, (c) gender, (d) ethnicity, (e) SBDM council position, (f) perception of receiving relevant information for decision-making, (g) use of committees, (h) perception of relevance of training activities, (i) school level, and (j) level of efficiency score? The researcher performed a regression analysis using the dependent variable average efficacy score and the independent variables. In this analysis, ethnicity is African American and white. Appendix F presents the results of a second regression analysis. In the latter, ethnicity is minority (African American, Asian, Hispanic, other) or white. The researcher believed it was more appropriate to report the regression using the dichotomous ethnicity variable African American/white. The two ethnic groups made up over $96 \%$ of the sample. Furthermore, the results reflecting all ethnicities (i.e., using minority/white) were very similar to results reported within this chapter.

Table 6 shows the means, standard deviations, and correlations for variables used in the regression in which efficacy score was the dependent variable. The first row of the table contains bivariate correlations between the dependent variable efficacy and the regression predictors. Results indicate several significant positive relationships, notably for the predictors relevant information, use of committees, and training activities.

Table 7 shows regression coefficients for the regression analysis. The regression model containing the set of 11 predictors was statistically significant, $F(11,591)=22.69$, $p<.001$. The squared multiple correlation was $\mathrm{R}$ squared $=.297$ (adjusted $\mathrm{R}$ squared $=$ 
.284 ), indicating that the predictors accounted for about $28 \%$ of the variance in efficacy. This could be considered a moderate effect size (Cohen, J., Cohen, P., West, \& Aiken, 2003).

There were four significant predictors: Contrast between parents and teachers/staff, relevant information, use of committees, and training activities. The significant effect for this coefficient meant that, controlling for all other predictors in the equation, parents rated the efficacy of councils higher than teacher/staff. For the other three significant predictors, the greater the rating for the variable (holding other predictors constant), the higher the efficacy score. For example, the higher the rating on relevant information, the higher the overall score on efficacy.

The last column of Table 7 shows squared semi-partial correlations for significant predictors, interpreted as the proportion of variance in efficacy that is uniquely attributable to a variable. For example, relevant information had the squared semi-partial correlation of .11. This means that of the total proportion of variance in efficacy that is accounted for by the predictors $\left(\mathrm{R}^{2}=.297\right), .11$ was uniquely predicted by the variable relevant information. 
Table 6

Means, Standard Deviations, and Correlations for Regression with Dependent Variable Efficacy $(N=603)$.

\section{Variable}

$M \quad S D$

$S D \quad 1$

$$
2
$$

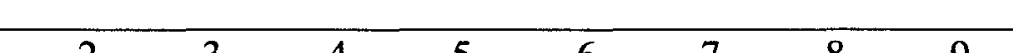

Efficacy

$\begin{array}{lllllllllllllll}3.46 & .45 & .00 & -.04 & .01 & .00 & .09 * & .01 & .47 * * & .34 * * & .34 * * & -.05 & .08^{*} \\ 2.99 & .78 & - & .33 * * & .03 & .01 & .05 & .22 * * & -.03 & -.08^{*} & .00 & .05 & .01 \\ 2.24 & 1.04 & - & - & .03 & -.05 & -.23 * * & .40 * * & .00 & -.02 & -.06 & -.03 & .02 \\ .75 & .43 & - & - & - & .06 & -.02 & -.03 & -.02 & -.03 & .07 * & -.34 * * & .08^{*} \\ .21 & .41 & - & - & - & - & -.09 * & .04 & -.06 & .10^{* *} & .14^{* *} & -.08^{*} & .09 *\end{array}$

$\bar{\omega} \quad$ 5. Contrast between parents and teachers/staff

$$
.28
$$

\begin{tabular}{|c|c|c|c|c|c|c|c|c|c|c|c|c|c|}
\hline and teachers/staff & .14 & .35 & - & - & - & - & - & - & $.07 *$ & -.05 & -.02 & $-.08 *$ & .06 \\
\hline 7. Relevant information & 3.71 & .51 & - & & - & - & - & - & - & $.27 * *$ & $.31 * *$ & -.03 & .03 \\
\hline 8. Use of committees & 3.23 & .80 & - & - & - & - & - & - & - & - & $.40^{* *}$ & $-.09 *$ & $.09^{*}$ \\
\hline 9. Training activities & 3.26 & .70 & - & - & - & - & - & - & - & - & - & -.06 & $.08^{*}$ \\
\hline 10. School level & 1.63 & .81 & - & - & - & - & - & - & - & - & - & - & $-.14^{* *}$ \\
\hline 11. Level of efficiency & 2.79 & .88 & - & - & - & - & - & - & - & - & - & - & - \\
\hline
\end{tabular}

6. Contrast between principals

Note. Gender was coded: female $=1$, male $=0$; Ethnicity was coded: African American $=1$, White $=0 .{ }^{*} p<.05^{* *} p<.01$ 
Table 7

Partial Coefficients for Regression with Dependent Variable Efficacy $(N=603)$.

\begin{tabular}{lllll}
\hline Variable & B & SEB & $\beta$ & $\mathrm{sr}^{2}$
\end{tabular}

$\begin{array}{llll}\text { Constant } & 1.53 & .16 & \\ \text { Age } & .02 & .02 & .03 \\ \text { Years on council } & -.01 & .02 & -.03 \\ \text { Gender } & .00 & .04 & .00 \\ \text { Ethnicity } & -.03 & .04 & -.02\end{array}$

Contrast between parents

$\begin{array}{lllll}\text { and teachers/staff } & .08 & .04 & .08^{*} & .01\end{array}$

Contrast between principals

and teachers/staff $\quad .02 \quad .05 \quad .01$

$\begin{array}{lcccc}\text { Relevant information } & .32 & .03 & .36^{* *} & .11 \\ \text { Use of committees } & .10 & .02 & .18^{* *} & .03 \\ \text { Training activities } & .10 & .03 & .16^{* *} & .02 \\ \text { School level } & -.01 & .02 & -.01 & \\ \text { Level of efficiency } & .02 & .02 & .04 & \end{array}$

Note. Gender was coded: female $=1$, male $=0$; Ethnicity was coded: African American

$=1$, White $=0 . \mathbf{s r}^{2}$ are squared semipartial correlations for significant predictors.

For this model: $\mathrm{R}^{2}=.297$ (adjusted $\mathrm{R}^{2}=.284$ ).

$* p<.05 \quad * * p<.01$ 
For African American and white only as well as minority and non-minority, the assumptions of normality of residuals, outliers, homoscedasticity, collinearity, and linearity met with the same results. The histogram generated by SPSS revealed a primarily bell-shaped curve and the p-plot showed the residuals close to the line of normal distribution. The mean for Cook's Distance, which indicates the degree an outlier influence variables, was .002, far below the requirement of less than 1 . The mean for Centered Leverage Value, which indicates the degree an independent variable influences other independent variables, was .018 , meeting the requirement that the number be close to 0 . For homoscedacity, the researcher examined the residual plot to determine that there was an even distribution of plots centered around 0 . The researcher tested collinearity by examining the tolerance to ensure that it was larger than .1. In each case it was. The Variance Inflation Factor for each variable was less than 10, meeting the requirements of the test. Through an examination of the residual plot, linearity determined whether the amount of change in $\mathrm{y}$ in relation to $\mathrm{x}$ was constant. The points were equally distributed around 0 , thus meeting the requirements.

Additionally, the results met the assumptions of multiple regression (Osbourne \& Waters, 2002), variables normally distributed, measured without error (Cronbach's Alpha of greater than .7-.8), a linear relationship between the independent and dependent variables, and the plot of standard residuals revealed homoscedasticity. The sample size and number of predictor variables are consistent with Stevens' (1996) assertion that "for social science research, about 15 subjects per predictor are needed for a reliable equation" (p. 72). 


\section{Analysis for Research Question 4}

Research Question 4 was the following, "How much variance in the average productivity score can be predicted by the following independent variables: (a) age, (b) number of years served on council, (c) gender, (d) ethnicity, (e) SBDM council position (principal, teacher, or parent), (f) perception of receiving relevant information for decision-making, (g) use of committees, (h) perception of relevance of training activities, (i) school level, and (j) level of efficiency score?" The researcher performed a regression analysis twice using the dependent variable average productivity score and the independent variables. During the first analysis, they researched ethnicity as African American and white and during the second analysis (see Appendix F) minority and white.

Table 8 shows the means, standard deviations, and correlations for variables used in the regression in which productivity score was the dependent variable. The first row of the table contains bivariate correlations between productivity score and the regression predictors. The researcher found several significant relationships, the strongest of which were for the predictors relevant information, use of committees, training activities and level of efficiency.

Table 9 shows regression coefficients for the regression analysis. The regression model containing the set of 11 predictors was statistically significant, $F(11,595)=20.42$, $p<.001$. The squared multiple correlation was $\mathrm{R}$ squared $=.274$ (adjusted $\mathrm{R}$ squared $=$ .261 ), indicating that about $26 \%$ of the variance in efficacy accounted for the predictors, a moderate effect size (Cohen, J., Cohen, P., West, \& Aiken, 2003).

There were six significant predictors: Contrast between parents and 
teachers/staff, relevant information, use of committees, training activities, school level, and level of efficiency. The significant effect for this coefficient meant that, controlling for all other predictors in the equation, teachers/staff rated the productivity of councils higher than parents. Interpreting four of the significant predictors, the greater the rating for the variable (holding other predictors constant), the higher the productivity score. For example, the higher the rating on relevant information, the higher the overall score on productivity.

For one of the predictors, an inverse relationship was evident. This was school level. The negative sign for the standardized regression coefficient $(\beta=-.085)$ indicated that the lower the school level, the greater the perceived productivity. Thus, SBDM participants in elementary schools had higher productivity scores than those in high schools.

The last column of Table 9 shows squared semi-partial correlations for significant predictors, the proportion of variance in productivity that is uniquely attributable to a variable. For example, relevant information had the squared semi-partial correlation of .07 . This means that of the total proportion of variance in productivity that is accounted for by the predictors $\left(\mathrm{R}^{2}=.274\right), .07$ was uniquely predicted by the variable relevant information. 
Table 8

Means, Standard Deviations, and Correlations for Regression with Dependent Variable Productivity $(N=607)$.

\begin{tabular}{|c|c|c|c|c|c|c|c|c|c|c|c|c|c|}
\hline$\overline{\text { Variable }}$ & $M$ & $S D$ & 1 & 2 & 3 & 4 & 5 & 6 & 7 & 8 & 9 & 10 & 11 \\
\hline Productivity & 3.48 & .47 & -.02 & .02 & -.01 & .02 & -.08 & .04 & $.40 * *$ & $.34 * *$ & $.36 * *$ & $-.12 * *$ & $.16^{* *}$ \\
\hline 1. Age & 2.99 & .78 & - & $.33 * *$ & .04 & .01 & .06 & $.22 * *$ & -.04 & $-.08 *$ & .00 & .05 & .01 \\
\hline 2. Years on council & 2.24 & 1.04 & - & - & .02 & -.06 & $-.23 * *$ & $.40 * *$ & .00 & -.01 & -.06 & -.03 & .02 \\
\hline 3. Gender & .75 & .44 & - & - & - & .06 & -.01 & -.04 & -.02 & -.03 & .07 & $-.34 * *$ & $.08 *$ \\
\hline 4. Ethnicity & .21 & .41 & - & - & - & - & $-.09 *$ & .04 & -.06 & $.10 * *$ & $.15 * *$ & $-.08 *$ & $.09 *$ \\
\hline
\end{tabular}

$\varpi$ 5. Contrast between parents

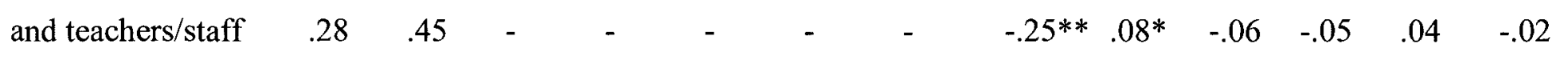

6. Contrast between principals

\begin{tabular}{|c|c|c|c|c|c|c|c|c|c|c|c|c|c|}
\hline and teachers/staff & .14 & .35 & - & - & - & - & - & - & $.07 *$ & -.04 & -.02 & $-.08 *$ & .06 \\
\hline 7. Relevant information & 3.71 & .51 & 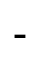 & - & - & - & - & 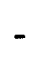 & - & $.28 * *$ & $.32 * *$ & -.04 & .04 \\
\hline 8. Use of committees & 3.24 & .80 & - & - & - & - & - & - & - & - & $.40^{* *}$ & $-.10^{* *}$ & $.10^{* *}$ \\
\hline 9. Training activities & 3.26 & .70 & 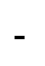 & - & - & - & - & - & - & - & - & -.07 & $.09^{*}$ \\
\hline 10. School level & 1.62 & .81 & - & - & - & - & - & - & - & - & - & - & $-.14 * *$ \\
\hline 11. Level of efficiency & 2.80 & .88 & - & - & - & - & - & - & - & - & - & - & - \\
\hline
\end{tabular}

Note. Gender was coded: female $=1$, male $=0$; Ethnicity was coded: African American $=1$, White $=0 .{ }^{*} p<.05 \quad{ }^{* *} p<.01$ 


\section{Table 9}

Partial Coefficients for Regression with Dependent Variable Productivity $(N=607)$.

$\begin{array}{lllll}\text { Constant } & \text { B } & \text { SEB } & \beta & \mathrm{sr}^{2}\end{array}$

\begin{tabular}{|c|c|c|c|c|}
\hline Constant & 1.72 & .17 & .01 & \\
\hline Age & .01 & .02 & .01 & \\
\hline Years on council & .00 & .02 & .01 & \\
\hline Gender & -.05 & .04 & -.05 & \\
\hline Ethnicity & -.03 & .04 & -.03 & \\
\hline \multicolumn{5}{|l|}{ Contrast between parents } \\
\hline and teachers/staff & -.09 & .04 & $-.08^{*}$ & .01 \\
\hline \multicolumn{5}{|c|}{ Contrast between principals } \\
\hline and teachers/staff & -.01 & .05 & -.01 & \\
\hline Relevant information & .27 & .04 & $.29 * *$ & .07 \\
\hline Use of committees & .10 & .02 & $.16^{* *}$ & .02 \\
\hline Training activities & .13 & .03 & $.19 * *$ & .03 \\
\hline School level & -.05 & .02 & $-.09 *$ & .01 \\
\hline Level of efficiency & .05 & .02 & $.11 * *$ & .01 \\
\hline
\end{tabular}

Note. Gender was coded: female $=1$, male $=0 ;$ Ethnicity was coded: African American $=1$, White $=0 . \mathbf{s r}^{2}$ are squared semipartial correlations for significant predictors. For this model: $\mathrm{R}^{2}=.274$ (adjusted $\mathrm{R}^{2}=.261$ ); $\quad{ }^{*} p<.05 \quad{ }^{* *} p<.01$ 
For this regression with productivity as the dependent variable, the assumptions of normality of residuals, outliers, homoscedacity, collinearity, and linearity met with the same results. The histogram generated by SPSS revealed a primarily bell-shaped curve and the p-plot showed the residuals close to the line of normal distribution. The mean for Cook's Distance, which indicates the degree an outlier influence variables, was .002, far below the requirement of less than 1 . The mean for Centered Leverage Value, which indicates the degree an independent variable influences other independent variables, was .018 , meeting the requirement that the number be close to 0 . For homoscedacity, the researcher examined the residual plot to determine that there was an even distribution of plots centered around 0 . The researcher tested Collinearity by examining the tolerance to ensure that it was larger than .1. In each case it was. The Variance Inflation Factor for each variable was less than 10 , meeting the requirements of the test. Through an examination of the residual plot, linearity determined whether the amount of change in y in relation to $\mathrm{x}$ was constant. The points were equally distributed around 0 .

Additionally, the results met the assumptions of multiple regression (Osbourne \& Waters, 2002), variables normally distributed, measured without error (Cronbach's Alpha of greater than .7-.8), a linear relationship between the independent and dependent variables, and the plot of standard residuals revealed homoscedasticity. The sample size and number of predictor variables are consistent with Stevens' (1996) assertion that "for social science research, about 15 subjects per predictor are needed for a reliable equation" (p. 72). 


\section{Analysis for Research Question 5}

Research Question 5 asked, "For the SBDM council positions teacher and parent, how much variance in average efficacy score is within schools and between schools?" To address this question, the researcher performed two random effects analyses of variance (ANOVA). In each, the independent variable was the school and the dependent variable was average efficacy score. The first ANOVA examined teachers, the second ANOVA examine parents. Because some schools did not have a large number of respondents for a particular position, data editing was necessary. The researcher analyzed data for schools that had at least two respondents for a given position. For example, if fewer than two teachers in a school responded to the questionnaire, that school was not analyzed. The consequence of this data editing meant a reduction in the number of schools that were used. The researcher analyzed parent data from 70 schools and teacher data from 112 schools.

Table 10 shows a summary of the random effects ANOVA for average efficacy scores by school. There were significant differences among schools both for teachers, $F(110,273)=2.07, p<.01$, and for parents, $F(68,92)=1.55, p<.05$. The researcher calculated the intraclass correlation for each ANOVA. The intraclass correlation justifies the use of the random effects ANOVA instead of a fixed effects ANOVA because the intraclass correlation was approximately less than $10 \%$. For teachers, this was .23 and for parents it was .19. These values represent the proportion of variance in efficacy that could be attributed to differences in schools. For example, .23 of the variance of teacher efficacy ratings was between schools, meaning the remaining .67 of variance was due to individual factors of teachers within schools. 
Table 10

Random Effects ANOVA for Efficacy by School.

\begin{tabular}{llllll}
\hline Variable & SS & df & MS & $F$ & Sig. \\
\hline Teachers & & & & & \\
Between groups & 38.17 & 110 & .35 & 2.07 & .00 \\
Within groups & 45.74 & 273 & .17 & & \\
Total & 83.91 & 383 & & & \\
& & & & & \\
Parents & & 68 & .19 & 1.55 & .03 \\
Between groups & 12.81 & 62 & .12 & & \\
Within groups & 11.20 & 92 & & & \\
Total & 24.01 & 160 & & & \\
\hline
\end{tabular}

Note. Intraclass correlations were: (a) for teachers, .23; (b) for parents, .19 .

\section{Analysis for Research Question 6}

Research Question 6 asked, "For the SBDM council positions teacher and parent, how much variance in average productivity score is within schools and between schools?" The question the researcher addressed in a similar fashion as Research Question 5: calculating two random effects ANOVA using average productivity scale scores as the dependent variable and schools as the independent variable. Table 11 shows summaries of the random effects ANOVA. There were significant differences among schools both for teachers, $F(110,281)=2.59, p<.01$, and for parents, $F(69,93)=$ $1.72, p<.05$. The intraclass correlations for the two analyses were: (a) for teachers, .31 ; (b) for parents, .23 .

\section{Possible Additional Analyses of Efficacy and Productivity Data}

The results for Research Questions 5 and 6 indicated that differences among 
schools account for the substantial proportion of variance in ratings. Other researcher may pursue additional research following up these findings, including multilevel analyses (e.g., hierarchical linear modeling) could be pursued. However, the limitation in these data concern the relatively small number of cases per school. On the average, there were 3.5 teachers per school that responded and 2.3 parents per school. These small numbers make the sampling error very large in each school. The value of multilevel analysis is questionable.

Table 11

Random Effects ANOVA for Productivity by School.

\begin{tabular}{lccccc}
\hline Variable & SS & df & MS & $F$ & Sig. \\
\hline Teachers & & & & & \\
Between groups & 39.57 & 110 & .35 & 2.59 & .00 \\
Within groups & 39.06 & 281 & .14 & & \\
Total & 78.63 & 391 & & & \\
& & & & & .008 \\
Parents & & 69 & .34 & 1.72 & \\
Between groups & 23.32 & 93 & .197 & & \\
Within groups & 18.32 & 162 & & & \\
Total & 41.64 & 162 & & & \\
& & & &
\end{tabular}

Note. Intraclass correlations were: (a) for teachers, .31 ; (b) for parents, .23.

\section{Summary of the Results}

The results of the study showed that, in general, council members had a positive perception of the productivity and efficacy of the councils. There were no differences between the perceptions of parents and principals, nor between principals and 
teachers/staff. There was, however, a difference between parents and teachers/staff in regards to efficacy, with parents revealing a higher rating than teachers. Although the difference was statistically significant, it was small in magnitude.

Research Questions 3 and 4 further explored the amount of variance in efficacy and productivity in relation to several predictor variables. The contrast between parents and teachers/staff, relevant information, use of committees, and training activities could predict the amount of variance in the average efficacy score. The contrast between parents and teachers/staff, relevant information, use of committees, training activities, school level, and level of efficiency could predict the amount of variance in the average productivity score. Additionally, there were significant differences among schools both for teachers and for parents in regards to both efficacy and productivity.

Table 12 gives the summary in brief form. 
Table 12

Results of Analyses Addressing Research Questions

\begin{tabular}{|c|c|c|}
\hline $\begin{array}{l}\text { Research } \\
\text { Question }\end{array}$ & Question & Most important results \\
\hline 1 & $\begin{array}{l}\text { To what degree do school stakeholders } \\
\text { consider school councils to have efficacy } \\
\text { and to be productive? }\end{array}$ & $\begin{array}{l}\text { Council members had a positive } \\
\text { perception of the productivity } \\
\text { and efficacy of the councils. }\end{array}$ \\
\hline 2 & $\begin{array}{l}\text { Do the various constituencies differ in their } \\
\text { perceptions of the council efficacy and } \\
\text { productivity? }\end{array}$ & $\begin{array}{l}\text { There were no differences } \\
\text { between parents and principals } \\
\text { on average ratings of } \\
\text { productivity and efficacy. } \\
\text { Neither was there a difference } \\
\text { between principals and } \\
\text { teachers/staff. One difference } \\
\text { showed that parents had a } \\
\text { higher rating for efficacy than } \\
\text { teachers/staff. }\end{array}$ \\
\hline 3 & $\begin{array}{l}\text { How much variance in the average efficacy } \\
\text { score can be predicted by the following } \\
\text { independent variables: (a) age, (b) number } \\
\text { of years served on council, (c) gender, (d) } \\
\text { ethnicity, (e) SBDM council position } \\
\text { (principal, teacher, or parent), (f) } \\
\text { perception of receiving relevant } \\
\text { information for decision-making, (g) use of } \\
\text { committees, (h) perception of relevance of } \\
\text { training activities, (i) school level, and (j) } \\
\text { level of efficiency score? }\end{array}$ & $\begin{array}{l}\text { For the set of predictors, } \mathrm{R}^{2}= \\
.284, \text { indicating approximately } \\
28 \% \text { of the variance in average } \\
\text { efficacy accounted for by the } \\
\text { predictors. There were four } \\
\text { significant predictors: relevant } \\
\text { information, use of committees, } \\
\text { the contrast between parents } \\
\text { and teachers/staff, and training } \\
\text { activities. }\end{array}$ \\
\hline 4 & $\begin{array}{l}\text { How much variance in the average } \\
\text { productivity score can be predicted by the } \\
\text { following independent variables: (a) age, } \\
\text { (b) number of years served on council, (c) } \\
\text { gender, (d) ethnicity, (e) SBDM council } \\
\text { position (principal, teacher, or parent), (f) } \\
\text { perception of receiving relevant } \\
\text { information for decision-making, (g) use of } \\
\text { committees, (h) perception of relevance of } \\
\text { training activities, (i) school level, and (j) } \\
\text { level of efficiency score? }\end{array}$ & $\begin{array}{l}\text { For the set of predictors, } \mathrm{R}^{2}= \\
.261, \text { indicating approximately } \\
26 \% \text { of the variance in average } \\
\text { productivity was accounted for } \\
\text { by the predictors. There were } \\
\text { six significant predictors: the } \\
\text { contrast between parents and } \\
\text { teachers/staff, relevant } \\
\text { information, use of committees, } \\
\text { training activities, school level, } \\
\text { and level of efficiency. }\end{array}$ \\
\hline
\end{tabular}


Table 12 (continued)

\begin{tabular}{|l|l|l|}
\hline $\begin{array}{l}\text { Research } \\
\text { Question }\end{array}$ & Question & Most important results \\
\hline 5 & $\begin{array}{l}\text { For the SBDM council positions teacher } \\
\text { and parent, how much variance in average } \\
\text { efficacy score is within schools and } \\
\text { between schools? }\end{array}$ & $\begin{array}{l}\text { Based on the calculation of } \\
\text { intraclass coefficients, the } \\
\text { proportions of variance in } \\
\text { efficacy scores between-schools } \\
\text { were: (a) teachers, .23; } \\
\text { (b) parents, .19. The remaining } \\
\text { variance was within schools. }\end{array}$ \\
\hline 6 & $\begin{array}{l}\text { For the SBDM council positions teacher } \\
\text { and parent, how much variance in average } \\
\text { productivity score is within schools and } \\
\text { between schools? }\end{array}$ & $\begin{array}{l}\text { Based on the calculation of } \\
\text { intraclass coefficients, the } \\
\text { proportions of variance in } \\
\text { productivity scores between- } \\
\text { schools were: (a) teachers, } .31 ; \\
\text { (b) parents, .23. The remaining } \\
\text { variance was within schools. }\end{array}$ \\
\hline
\end{tabular}




\section{CHAPTER V}

\section{DISCUSSION}

This study addresses the perceptions of Kentucky SBDM council members concerning the productivity and efficacy of the councils. An additional purpose is to study how perceptions of productivity and efficacy affect variables measured on council members. These variables included: (a) council position (principal, parent, teacher), and (b) demographic characteristics (e.g., number of years served on council). Finally, the study examined how much variability in perceptions attributes to individual council members and how much attributes to schools.

The problem addressed in this study is the lack of information about perceptions of SBDM functioning. Specifically, there is lack of information from individuals serving in the three SBDM positions: principal, parent, and teacher. Of these positions, the parent position is most problematic. The principal and teacher SBDM council members control the majority of the decision making on the councils. Educators control the agendas, meeting times, and dissemination of information during these meetings (Malen, Ogawa, \& Krantz, 1990b). The principal controls the discussions and decisions and the teachers are only able to affect the decision making if the principal remains neutral on the 
topic being discussed. Parents have even less power in the decision making process because educators tend to protect their professional sovereignty. Parents have difficulty expressing their concerns. When they are comfortable enough to express their concerns, parents reported being quickly silenced (Ogawa \& White, 1994).

This study built on previous research by Johnson and Logan (2000). They examined "the perceptions of school stakeholders regarding the efficacy and productivity of SBDM councils in Kentucky” (p. 316). They questioned: “(1) To what degree do school stakeholders consider school councils to be effective and productive? and (2) Do the various constituencies differ in their perceptions of the council efficacy and productivity? Are there differences between constituents serving on councils and those not on councils?"(p. 317). The study determined how Kentucky SBDM council members perceived the productivity and efficacy of the councils and explored variables measured on council members.

\section{Discussion}

\section{Descriptive Statistics}

The Jefferson County Public Schools Office of SBDM collected survey data during March and April of 2010. The study participants were administrators $(n=105)$, parents $(n=196)$, and teachers/staff $(n=395)$ who were members of School-Based Decision Making councils $(N=707)$. Eleven participants elected not to report their position on the council. The overall percentages (principals $15.1 \%$, parents $28.2 \%$, and teachers 55.9\%) accurately reflected the standard composition of the councils (principals $16.6 \%$, parents $33.3 \%$, and teachers $50 \%$ ). 
The percentages of respondents represented each level of schooling: elementary $58 \%$, middle $19.8 \%$, and high $22.2 \%$. The percentage of respondents from the elementary level was lower than the composition of schools in Jefferson County that have SBDM councils (elementary 68\%). The percentages for middle and high schools were somewhat higher than the district's percentages (middle 16.6\%, and high school 15.9\%). The original survey sample included three special schools, they were excluded from the study. All members of the SBDM council during the 2009-10 school year received the survey. The SBDM council chairperson received the survey via the interoffice mail delivery system. A letter enclosed with the survey instructed the SBDM chairperson (See Appendix C) to distribute them to council members during the next scheduled SBDM meeting. At that meeting council members had the opportunity to complete the survey. The researcher received the completed surveys via the interoffice mail delivery system. The participants self-reported demographic characteristics, completed the School Council Efficacy Scale (SCES) and School Council Productivity Scale (SCPS), as well as other items unrelated to this research. This process was consistent with the distribution of past survey instruments to SBDM council members since 1996.

\section{Data Analysis}

Statistical analysis for this study consisted of descriptive and inferential statistical procedures that are appropriate for each research question. The statistical procedures conducted and a brief summary of the results are as follows.

The analysis used descriptive statistics (e.g. means and standard deviations) were employed to determine the degree that schools stakeholders consider school councils to have efficacy and to be productive. Overall, council members had a positive perception 
of the productivity and efficacy of the councils. The mean for productivity was 3.48 , indicating that participants perceived SBDM policies to affect student achievement between an average and high level. The mean for efficacy was 3.47. Since the closer the response to four, the higher the efficacy, this indicates that council members were between agree to strongly agree that the council had efficacy.

ANOVA determined whether or not the various constituencies differ in their perceptions of the council efficacy and productivity. There were no differences between the perceptions of parents and principals, nor between principals and teachers/staff. There was, however, a difference between parents and teachers/staff in regards to efficacy, with parents revealing a higher rating than teacher. Although the difference was statistically significant, it was small in magnitude.

Multiple regression assisted in the determination of how much variance in the average efficacy score independent variables predict: (a) age, (b) number of years served on council, (c) gender, (d) ethnicity, (e) SBDM council position (principal, teacher, or parent), (f) perception of receiving relevant information for decision-making, (g) use of committees, (h) perception of relevance of training activities, (i) school level, and (j) level of efficiency score. The researcher conducted the same analysis substituting the productivity score as the dependent variable. This analysis revealed that the amount of variance in the average efficacy score predicts the contrast between parents and teachers/staff, relevant information, use of committees, and training activities. The analysis revealed that the amount of variance in the average productivity score predicts the contrast between parents and teachers/staff, relevant information, use of committees, training activities, school level, and level of efficiency. 
ANOVA determined the amount of variance in the average efficacy score within schools and between schools for the SBDM council positions teacher and parent. The analysis used this same process, substituting the productivity score as the dependent variable. It revealed that there were significant differences among schools both for teachers and for parents in regards to both efficacy and productivity. The proportion of variance in ratings attributed to schools ranged from .19 (efficacy ratings of parents) to .31 (productivity ratings of teachers).

\section{How the Study Relates to Past Research}

This research refutes early research findings about the decisions made by the councils and the lack of focus by the councils on curriculum and instruction but confirms much of Johnson and Logan's (2000) findings. The results of this research may indicate that improvements may have been made since the inception of SBDM councils. In 1990, Malen, Ogawa, and Krantz (1990a) reviewed over 200 documents relating to SBM in the United States, Australia, and Canada. While the results of their study were overwhelmingly positive, a deeper look at the role of the parents on the council was not. The researchers found that educators controlled the agenda, meeting time and location, and dissemination of knowledge. Parents were unwilling to break the mold where the teachers teach and the administrators make all decisions. The high rate of efficacy among the SBDM parent council members found in this current research indicates that this may no longer be true.

A case study also completed by Malen, Ogawa, and Krantz (1990b) in 1990 indicated that the distribution of power varies from school to school and that the 
decisions made by the councils were mundane and trivial and rarely dealt with issues such as curriculum or instruction. A 1995 study by the Kentucky Institute for Education Research had similar findings. The results of this current research refute these findings. When asked to respond to the statement "The council is secure in its ability to make a difference in the school," the mean response on the 4-point Likert scale item was 3.47, indicating that the majority of the participants agree to strongly agree with the statement. Another statement asked them to respond to the statement "The council handles unexpected problems well," the mean response was 3.38 , again indicating that the participants agreed to strongly agreed with the statement. When asked to indicate the extent to which policies affected student achievement, the mean response for the curriculum policy was 3.64 and the instruction policy was 3.55 , again indicating that participants felt that these policies had an average or high effect on student achievement. The difference between the research now and over twenty years ago indicates that the current councils may have more decision making authority and that the decisions being made deal with issues such as curriculum and instruction, which leads to increases in student achievement.

Lindle's 1996 study about decision making in Kentucky determined that teachers and parents felt that their attempts to make any substantial contributions were quickly thwarted. This contrasts with the current findings in this study. When asked to respond to the statement "The council has no way to ensure that decisions will be implemented," the mean average response indicated that most participants indicated that they disagreed to highly disagreed with the statement. When asked to respond to the statement, "The council's decisions are ignored by the school administration," the average response 
indicated that most participants indicated that they disagreed to highly disagreed with the statement. The current research indicates that both parents and teachers feel that the decisions made by the council are implemented and not ignored.

Johnson and Logan (2000) analyzed the means and standard deviations for the parents, teachers, and administrator groups within the productivity scale. The item that was rated the highest by all groups was "council bylaws" while principals rated "assessing student progress" as the lowest. Teachers rated "assigning students to classes" and "programs within the school" lowest while parents indicated that "instructional" and "non-instructional staff time" were rated the lowest. They used a one-way ANOVA with the Scheffé test to compare the means in the efficacy scale $(F(4,676)=20.32, p<.001)$. This analysis revealed that council members' efficacy ratings were higher than noncouncil members. Among the council members, parents rated significantly higher than teachers or principals. The current research confirms this finding, indicating that parents rated higher than teachers on efficacy. This was not the case for principals. A possible reason for this could be that participation on the council increases parental efficacy. Prior to the implementation of SBDM councils, parents had no voice in the decision making process, but principals and teachers did.

Schlinker, Kelley, and O'Phelan, and Spall (2008) surveyed past council members for their study Support and Resources for Site-Based Decision-Making Councils: Perceptions of Former Council Members of Two Large Kentucky School Districts. Jefferson County Public Schools was not one of the districts surveyed. Their findings indicated that $85 \%$ of the participants described the council as effective, but only $45 \%$ reported that the council contributes to student achievement. The perceptions of 
effectiveness were slightly lower than the current research, but the perception of the council's contribution to student achievement was much lower. This was inconsistent with this study as the means for the SCES were between 3.38 and 3.60, indicating that participants felt that the policies had an average to high effect on student achievement. This inconsistency could reveal that disconnect between the school districts.

\section{Implications for Practice}

Policy makers at both the state and local level may benefit from the positive nature of the results of this study. The results indicate that council members have positive perceptions of the productivity and efficacy of the councils. Since those groups with high collective efficacy are more likely to assume more complex tasks, utilize their resources well, follow-through with tasks, and are less vulnerable to discouragement (Bandura, 1998), the perceptions of high efficacy among council members could indicate that they are likely to positively influence policy-development at the school level and should continue to do so.

Respondents indicated that SBDM policies affect student achievement between an average and high level. While this is a positive response, it should be higher as one of the roles of the council is to develop policies that increase student achievement. Those who support the councils should consider providing additional on-going support in the area of policy development. This could include both principals and district staff providing council members with more knowledge of the existing policies in place at the school and an understanding that the policies should be regularly reviewed to ensure that they still reflect the current practices of the school. Additionally, district personnel should develop 
exemplary sample policies for councils. The council chairperson and members should review annually these policies and make suggested revisions.

There were no differences between the perceptions of parents and principals, nor between principals and teachers/staff in the case of productivity. There was, however, a difference between parents and teachers/staff in regards to efficacy, with parents revealing a higher rating than teachers. This difference was small in magnitude, with the parent group having a higher mean on efficacy $(M=3.54)$ than the mean of the teacher/staff group $(M=3.43)$. District administrators should continue to monitor these perceptions to ensure that all role groups retain positive perceptions of the council. If these perceptions were to change among groups then administrators need to conduct further research to determine the cause.

Related to the average efficacy ratings, the strongest predictors were relevant information, use of committees, and training activities. This reveals the importance of ensuring that councils have relevant information, are willing to use committees, and complete their legally-required training. Practitioners should increase the dissemination of information to councils through the principal. Increased information to the principal or council chairperson during their regular meetings would flow to the council. KRS 160.345 mandates that council members receive annual training, but more is necessary. Councils should receive additional training on an as-needed basis when there are changes in the law, such as newly required policies. Districts should consider providing mentors or liaisons to each of the councils. If the availability of these mentors is not possible for all schools then they should be a priority for those struggling. The liaison or mentor could be a full time or retired employee, but must have experience working with councils. 
They would meet regularly with the council to disseminate new information, provide guidance, and answer questions. Additionally, they could observe council meetings and provide feedback to the chairperson about how to improve the effectiveness of the council. The information obtained by this person could then provide agenda items for chairperson follow-up training during the regularly scheduled district-wide principal meetings. Increasing the dissemination of information could result in increased efficacy.

Not all teachers and parents are able to participate on the council. The use of committees provides other parents, teachers, and community members the opportunity to provide input into the decision-making process. It also provides additional expertise that may not be available within the council. For example, if the council is reviewing their policy on technology utilization, stakeholders who work directly with technology both in and out of the building should be on a committee that would revise, review, or develop the policy. This participation could increase the efficacy of all stakeholders as well as provide an opportunity to utilize all resources within the school.

There were six significant predictors in determining the average productivity score: contrast between parents and teachers/staff, relevant information, use of committees, training activities, school level, and level of efficiency. The suggestions for practitioners mentioned previously could also apply to increased productivity but there are also additional implications as follows.

The correlation between relevant information and the perceived productivity of the council members indicates that council members feel more productive when they are given relevant information. Implications for practitioners could be the increased use of 
various modes of communication to disseminate information to council members. This could be in the form of regular newsletters that contain current information about best practices, changes in the law that affect the councils, upcoming training opportunities, and any other pertinent information that would increase their knowledge of relevant information. It could also be in the form of a website that is updated regularly with information and resources for council members. This website could contain training information, best practice information, resources, links to other websites, sample policies, as well as information about other councils, such as agendas, minutes, and member information.

While it is important to disseminate relevant information to council members, it is also vital that they have a way to communicate with district personnel and board of education members. This can be done through annual surveys similar to the one utilized in this research. The use of surveys provides districts with longitudinal information about the council members and their perceptions. This information can then be used to identify council member needs and then provide additional support. Council reports to the local board of education members are also necessary to improve communication between districts and schools. This could be in the form of written reports, discussions, or formal presentations and should occur regularly.

The use of committees was also correlated to the productivity score. The use of committees streamlines the process, allowing those who have the knowledge and expertise to participate in the decision making process and providing more depth to council decisions and policies. 
Another correlation was found between training activities and productivity. Practitioners should continue to provide the introductory activities to new council members while continuing to provide more challenging trainings to the experienced council members. The trainings provided for experienced council members should be specific to the council duties at the time of the training. For example, trainings that emphasize analysis of test scores and data should occur during the time the annual test scores are released and training on developing and monitoring the school budget should occur at the time that the council is developing the budget. Specific trainings at strategic times will provide meaningful support and encourage council members to attend additional trainings.

Currently, only those individuals who have become SBDM endorsed trainers are permitted to facilitate the mandated trainings. While expertise in the specific areas such as data analysis and budget are not prerequisites to facilitate these trainings, districts should consider encouraging those experts to become SBDM trainers. Having these experts available to council members through the trainings provides council members with a contact person should they have additional questions or concerns. It also provides them with a facilitator who has experience concerning the topic being addressed.

In addition to providing the trainings at the appropriate times with a facilitator who has an expertise in the area being discussed, the times of the trainings should take into consideration the schedules of the council members. While one-third of the council members work in the schools and have consistent schedules, this may not be the case for parent council members. Trainings should accommodate the varying work schedules of all council members and even consider providing childcare. 
The level of efficiency is an annual review of all SBDM councils in the areas of policy development, record keeping, and compliance with KRS 160.345. This review informs the SBDM council chairperson of potential improvements necessary to improve the efficiency of the council. Included in the review is a letter to the council chairperson that notifies them of any missing information or noncompliance issues, an efficiency scale with items specific to their council highlighted, and a policy spreadsheet which includes all of the council policies, their adoption dates, and suggested next steps. Based on the information in the review, the council receives a Level of Efficiency (1=not in compliance; $2=$ working toward compliance, $3=$ in compliance; $4=$ exceeding compliance). The appropriate assistant superintendent receives this information for follow-up and may be included in the principal's evaluation. The result of this study was that average efficiency rating was a significant predictor of productivity ratings. District personnel should monitor and assist those councils that have received a low efficiency score to improve their productivity. The correlation between the level of efficiency and the perceived level of productivity indicate that councils with higher efficiency scores could have higher productivity.

The analysis of the amount of variance in the average efficacy and productivity scores within schools and between schools for the SBDM council positions teacher and parent revealed significant differences among schools both for teachers and for parents. SBDM councils with low efficacy and productivity scores reported by both parents and teachers may benefit from additional monitoring on the part of district personnel as this may be indicative of struggling council leadership.

In future studies, researchers might expand the current study to explore similar 
data longitudinally. It might be particularly interesting, given that the survey instrument utilized in this study has been administered since 1996, to look at increases and decreases in perceived efficacy and productivity over time to determine causes and effects. It would also be interesting to incorporate the perceptions of non-council members into a future study.

\section{Conclusion}

KRS 160.345 mandates that SBDM councils composed of parents, teachers, and administrators are the primary decision makers in the school. They determine and monitor the curriculum and instruction strategies of the school. They analyze student data and determine student needs. In order for councils to be effective members must first perceive them to be efficacious and productive. Individual council members must perceive their roles on the council as vital to student achievement. 


\section{REFERENCES}

Bandura, A. (1977). Self-efficacy: Toward a unifying theory of behavioral change. Psychological Review, 84(2), 191-215.

Bandura, A. (1986). Social foundations of thoughts and action: Asocial cognitive theory. Englewood Cliffs, NJ: Prentice-Hall.

Bandura, A. (1991). Self-regulation of motivation through $s=$ anticipatory and selfregulatory mechanisms. In R. A. Dienstbier (Ed.), Perspectives on motivation: Nebraska symposium on motivation (Vol. 38, pp. 69-164). Lincoln: University of Nebraska Press.

Bandura, A. (1993). Perceived self-efficacy in cognitive development and functioning. Educational Psychologist, 28(2), 177-148).

Bandura, A. (1994). Self-efficacy. In V. S. Ramachaudran (Ed.), Encyclopedia of human behavior (Vol. 4, pp. 71-81). New York: Academic Press. (Reprinted in H. Friedman [Ed.], Encyclopedia of mental health. San Diego: Academic Press, 1998).

Bandura, A. (1998). Personal and collective efficacy in human adaptation and change. In J. G. Adair, \& K. L. Dion (Eds.), Advances in psychological science: Vol. 1. Personal, social and cultural aspects (pp. 51-71). Hove, UK: Psychology Press.

Bell, D. A. (1980). Brown v. Board of Education and the interest convergence dilemma. Harvard Law Review, 93(518), 518-533.

Bjork, L. G. \& Keedy, J. L. (2002). Decentralization and school council empowerment in Kentucky: Implications for community relations. Journal of School Public Relations, 23, 30-31.

Blackledge, A. (1995). Minority parents as school governors in Chicago and Britain: Empowerment or not? Educational Review, 47(3), 309-317.

Briggs, K. \& Wohlstetter, P. (2001). Key elements of a successful school-based management strategy. In J. Simmons (Ed), School reform in Chicago: Lessons and opportunities (351-372). Chicago: Chicago Community Trust. 
Bryk, A. S. \& Easton, J. Q. (1994). The state of Chicago school reform. Phi Delta Kappan, 76(1), 74-79.

Chavkin, N. \& Williams, D. L. (1993). Minority parents and the elementary schools: Attitudes and practices. In N. Chavkin (Ed.), Families and schools in a pluralistic society (pp. 74-105). Albany, NY: State University of New York Press.

Childress, S., Elmore, R., \& Grossman, A. (2006). How to manage urban school districts. Harvard Business Review.

Childress, S., Elmore, R., Grossman, A. S., \& King, C. (2007). Note on the PELP Coherence Framework. Public Education Leadership Project at Harvard University.

Collins, T. (1991). Reform and reaction: The political economy of education in Kentucky. Retrieved from ERIC database. (ED340540)

Cohen, J., Cohen, P., West, S. G., \& Aiken, L. S. (2003). Applied multiple regression/correlation analysis for the behavioral sciences $\left({ }^{\text {rd }}\right.$ ed.). Mahwah, $\mathrm{NJ}$ : Lawrence Erlbaum.

Comer, J. P. (1980). School power: Implications of an intervention project. New York: Free Press.

Comer, J. P. (1987). New Haven's school—community connection. Educational Leadership, 53(4), 13-16.

Comer, J. P. (2005). The rewards of parent participation. Educational Leadership, 62(6), $38-42$.

Covey, D. (1992). Implementing the eight correlates of school/site-based management. Phoenix, AZ: Paper presented at the $9^{\text {th }}$ Annual National Effective Schools Conference of the National School Conference Institute. Retrieved from ERIC database. (ED344298)

Cross, B. E. \& Reitzug, U. C. (1996). How to build ownership in city schools. Educational Leadership, 53(4), 16-19.

Dauber, S. L. \& Epstein, J. L. (1993). Parents' attitudes and practices of involvement in inner-city elementary and middle schools. In N. Chavkin (Ed.), Families and schools in a pluralistic society (pp. 74-105). Albany, NY: State University of New York Press.

David, J. L. (1994). School-based decision making: Kentucky's test of decentralization. Phi Delta Kappan, 75, 706-712. 
David, J. L. (1996). The who, what, and why of site-based management. Educational Leadership, 53(4), 4-9.

David, J. L. (2000). Educators and parents as partners in school governance. In R. Pankratz \& J. Petrosko (Eds.), All children can learn: Lessons from the Kentucky reform experience (pp. 244-262). San Francisco: Jossey-Bass.

Davies, D. (1993). Benefits and barriers to parent involvement: From Portugal to Boston to Liverpool. In N. Chavkin (Ed.), Families and schools in a pluralistic society (pp. 206-216). Albany, NY: State University of New York Press.

Din, F. (1997). The operations of Kentucky rural school councils. Retrieved from ERIC database. (ED413146)

Epstein, Sanders, Sheldon, Simon, Salinas, Jansorn, VanVoorhis, Martin, Thomas, Greenfield, Hutchins, \& Williams (2009). School, Family, and Community Partnerships: Your Handbookfor Action. Thousand Oaks, California: Corwin Press.

Etheridge, C. P., Hall, M. L. \& Brown, N. (1990). Leadership, control, communication and comprehension: Key factors in successful implementation of SBDM. Retrieved from ERIC database. (ED328655)

Etheridge, C. P. \& Hall, M. L. (1992). The impact of school-based decision making: A case study. Retrieved from ERIC database. (ED345361)

Etheridge, C. P. \& Hall, M. L. A. (1995). Challenge to change: The Memphis experience with school-based decision making revisited: Interrupted continuity. Retrieved from ERIC database. (ED386826)

Gamst, G., Myers, L. S., \& Guarino, A. J. (2008). Analysis of variance designs: $A$ conceptual and computational approach with SPSS and SAS. New York: Cambridge University Press.

Hall, G. \& Galluzzo, G. (1991). Changing policy into perspective: School-based decision making. Policy Issues. Retrieved from ERIC database. (ED346563)

Hargreaves, A. (2000). Professionals and parents: Personal adversaries or public allies? Prospects, 30(2), 201-213.

Harrington-Lueker, D. (1990). Kentucky starts from scratch. The American School Board Journal, 9, 17-21.

Harrison, C. R., Killion, J.P. \& Mitchell, J.E. (1989). Site-based management: The realities of implementation. Educational Leadership, 53(4), 55-58. 
Hess, G.A. Jr., (1991). School restructuring, Chicago style. Newbury Park, CA: Corwin Press.

Hinkle, D. E., Wiersma, W., Jurs, S. G. (2003). Applied statistics for the behavioral sciences (5th ed.). Boston: Houghton Mifflin.

Holland, H. (2000). A parent's viewpoint. In R. Pankratz \& J. Petrosko (Eds.), All children can learn: Lessons from the Kentucky reform experience (pp. 244-262). San Francisco: Jossey-Bass.

Hunter, M. (1999). All eyes forward: Public engagement and educational reform in Kentucky. Journal of Law and Education, 28(4), 485-516.

Johnson, M. J. \& Pajeres, F. (1996). When shared decision making works: A 3-year longitudinal study. American Educational Research Journal, 33, 599-627.

Kaba, M. (2001). “They listen to me...but they don't act on it": Contradictory consciousness and student participation in decision-making. The High School Journal, 84(2), 21-34.

Kannapel, P. J., Moore, B. D., Coe, P. C., \& Aagaard, L. (1994). School-based decision making in rural Kentucky schools: Interim findings of a five-year, longitudinal study. Retrieved from ERIC database. (ED371932)

Kannapel, P. J., Moore, B. D., Coe, P. \& Aagaard, L. (1995). Six heads are better than one? School-based decision making in rural Kentucky. Journal of Research in Rural Education, 11(1), 15-23.

Kentucky Association of School Councils (2008). The KASC SBDM Policy Toolkit. Danville, Kentucky: KASC.

Kentucky Department of Education (2000). Results matter: A decade of difference in Kentucky's public schools. Retrieved from http://www.education.ky.gov/NR/rdonlyres/EF0A1C1D-F709-44D3-8CC274E113172B51/0/10thAnniversaryReport.pdf

Kentucky Department of Education (2007, March 14). Kentucky's learning goals and academic expectations [Web page]. Retrieved from http://www.education.ky.gov/kde/instructional+resources/curriculum+documents +and+resources/academic+expectations/

Kentucky Institute for Education Research, Frankfort (1995). The implementation of Kentucky's school-based decision making program. Retrieved from ERIC database. (ED394977) 
Kim, Y. (2009). Minority parental involvement and school barriers: Moving the focus away from deficiencies of parents. Educational Research Review, 4, 80-102.

Lindle, J. C. (1992a). Challenges and successes with including Kentucky's parents in school-based decision making: Pilot year school councils respond. Retrieved from ERIC database. (ED410651).

Lindle, J. C. (1992b). Developing school based decision making capacities in Kentucky: Communication satisfaction after the pilot year. Retrieved from ERIC database. (ED378667)

Lindle, J. C. (1994). Kentucky's reform opens doors to family involvement. Dimensions of Early Childhood, 22(2), 20-22.

Lindle, J. C., Gale, B. S., \& Curry-White, B. S. (1994). School-based decision making: 1994 survey. Lexington, KY: University of Kentucky/University of Louisville Joint Center for the Study of Education Policy.

Lindle, J. C. (1996). Lessons from Kentucky about school-based decision making. Educational Leadership, 53(4), 20-23.

Lindle, J. C., Gale, B. S, \& Curry-White, B. (1996). Overview of Results from 1994 \& 1995 school-based decision making surveys. Retrieved from ERIC database. (ED424629)

Lutz, F. W. \& Iden, R. M. (1994). The political effects of site-based decision making in the state of Texas. Retrieved from ERIC database. (ED378636)

Malen, B., Ogawa, R. T. \& Kranz, J. (1990a). What do we know about school-based management? A case study of the literature-a call for research. In W. H. Clune, J. F. Witte (Eds.), Choice and control in American education, vol. 2 (pp. 289342). Philadelphia, PA: Falmer Press.

Malen, B. \& Ogawa, R. T. \& Krantz, J. (1990b). Site based management: Unfulfilled promises. The School Administrator, 8(47), 30-32, 53-57.

Malen, B. (1999). The promises and perils of participation on site-based councils. Theory into Practice, 38(4), 209-216.

National Commission on Excellence in Education (1983). A Nation at Risk. Retrieved from http://www.ed.gov/pubs/NatAtRisk/recomm.html

NCREL (1995). Decentralization: Why, how, and toward what ends? http:/www.ncrel.org/sdrs/areas/issues/envrnmnt/go/93-1mcgr.htm 
Nunnally, J. \& Bernstein, I. (1994) Psychometric theory (3 ${ }^{\text {rd }}$ ed.). New York: McGraw-Hill.

Ogawa, R. T. \& White, P. A. (1994). School-based management: An overview. In S. A. Mohrman, P. Wohlstetter, Associates (Eds.), School-based management: Organizing for high performance (pp 53-80). San Francisco: Jossey Bass.

Osbourne, J. \& Waters, E. (2002). Four assumptions of multiple regression that researchers should always test. Practical Assessment, Research and Evaluation, $8(2)$.

Ovando, M. N. \& Abrego, M. H. (1996). Parent involvement in a majority/minority context: Lessons from the field. Retrieved from ERIC database. (ED407728)

Parents United for Responsible Education (2006). Local School Council leadership guide. Retrieved from http://pureparents.org/data/files/coverandintro.pdf

Pankratz, R. \& Petrosko, J. (Eds.). (2000). All children can learn: Lessons from the Kentucky reform experience. San Francisco, CA: Jossey-Bass.

Russo, C. J. (1995a). School based decision making councils and school boards in Kentucky: Trusted allied or irreconcilable foes? Education Law Reporter, 97, 398-412.

Russo, C. J. (1995b). School-based decision making in Kentucky: Dawn of a new era or nothing new under the sun? Kentucky Law Journal, 83(1): 123-156.

Sandidge, R. F., Russo, C. J., Harris, J. J., Ford, H. H. (1996). School-based decision making, American Style: Perspectives and practices throughout the United States. Interchange, 27(3-4), 313-329.

Schlinker, W. R., Kelley, W. E., O'Phelan, M. H., \& Spall, S. (2008). Support and resources for site-based decision-making councils: Perceptions of former council members of two large Kentucky school districts. Florida Journal of Educational Administration and Policy, 2(1), 29-49.

Segal, L. (1997). The pitfalls of political decentralization and proposals for reform: The case of New York City Public Schools. Public Administration Review, 57(2), 141149.

Sexton, R. (2000). Engaging parents and citizens in school reform. In R. Pankratz \& J. Petrosko (Eds.), All children can learn: Lessons from the Kentucky reform experience (pp. 244-262). San Francisco, CA: Jossey-Bass.

Shatkin, G. \& Gershberg, A. I. (2007). Empowering parents and building communities: 
The role of school-based councils in educational governance and accountability. Urban Education, 42, 582-615.

Sheldon, S. B. (2009). Improving student outcomes with school, family, and community partnerships: A research review. In J. Epstein et al, School, Family, and Community Partnerships: Your Handbook for Action (pp. 40-56). Thousand Oaks, California: Corwin Press.

Smith, D.L., Valesky, T.C. \& Horgan, D.D. (1991). Impact of School Based Decision Making on school climate. Retrieved from ERIC database. (ED 331164)

Snider, W. (1991). Power sharing. Teacher Magazine, 2(5), 12-13.

Stevens, J. (1996). Applied Multivariate Statistics for the Social Sciences. Mahwah, New Jersey: Lawrence Erlbaum.

Stufflebeam, D.L. (1971). The relevance of the CIPP evaluation model for educational accountability. Retrieved from ERIC database. (ED062385)

Valesky, T., Smith, D. \& Horgan, D. (1990). Baseline data on school climate, classroom climate, and self concept as a learner in schools using School Based Decision Making. Retrieved from ERIC database. (ED326951)

Van Meter, E. (1991). The Kentucky Mandate: School-based decision making. NASSP Bulletin, 75(532), 52-62.

Van Meter, E. (1994). Improving school-based decision making in Kentucky. NASSP Bulletin, 78(563), 61-70.

Wanat, C. L. (1999). Parental involvement in the implementation of school reform. Journal for a Just and Caring Education, 5(3), 318-337.

Weiss, C. (1993). Shared decision making about what? A comparison of schools with and without teacher participation. Teachers College Record, 95(1), 69-92.

Westlaw Download Summary Report. (1989). Rose v. Council, 790 S.W.2d 186, 60 Ed. Law Rep. 1289 (1989). Retrieved November 3, 2009 from http://www.faculty.piercelaw.edu/redfield/library/case-rose.htm.

Western Kentucky University Libraries. (2008). KERA: Resources on the Kentucky Education Reform Act: Rose v. Council for Better Education. Retrieved November 3, 2009 from http://wku.edu/library/kera/rose.htm

Wohlstetter, P. (1990). Experimenting with decentralization: The politics of change. Retrieved from ERIC database. (ED337861) 
Wohlstetter, P. \& Briggs, K. (2001). Key elements of a successful school-based management strategy. In J. Simmons (Ed.), School reform in Chicago: Lessons and opportunities (pp. 351-372). Chicago, IL: Chicago Community Trust. 


\section{Appendix A}

KRS 160.345

160.345 Definitions - Required adoption of school councils for school-based decision making - Composition — Responsibilities - Professional development - Exemption - Formula for allocation of school district funds — Intentionally engaging in conduct detrimental to school-based decision making by board member, superintendent, district employee, or school council member - Complaint procedure - Disciplinary action Rescission of right to establish and powers of council - Wellness policy.

(1) For the purpose of this section:

(a) "Minority" means American Indian; Alaskan native; African-American; Hispanic, including persons of Mexican, Puerto Rican, Cuban, and Central or South American origin; Pacific islander; or other ethnic group underrepresented in the school;

(b) "School" means an elementary or secondary educational institution that is under the administrative control of a principal and is not a program or part of another school. The term "school" does not include district-operated schools that are:

1. Exclusively vocational-technical, special education, or preschool programs;

2. Instructional programs operated in institutions or schools outside of the district; or 
3. Alternative schools designed to provide services to at-risk populations with unique needs;

(c) "Teacher" means any person for whom certification is required as a basis of employment in the public schools of the state, with the exception of principals and assistant principals; and

(d) "Parent" means:

1. A parent, stepparent, or foster parent of a student; or

2. A person who has legal custody of a student pursuant to a court order and with whom the student resides.

(2) Each local board of education shall adopt a policy for implementing school-based decision making in the district which shall include, but not be limited to, a description of how the district's policies, including those developed pursuant to KRS 160.340, have been amended to allow the professional staff members of a school to be involved in the decision making process as they work to meet educational goals established in KRS 158.645 and 158.6451 . The policy may include a requirement that each school council make an annual report at a public meeting of the board describing the school's progress in meeting the educational goals set forth in KRS 158.6451 and district goals established by the board. The policy shall also address and comply with the following:

(a) Except as provided in paragraph (b)2. of this subsection, each participating school shall form a school council composed of two (2) parents, three (3) teachers, and the principal or administrator. The membership of the council may be increased, but it may only be increased proportionately. A 
parent representative on the council shall not be an employee or a relative of an employee of the school in which that parent serves, nor shall the parent representative be an employee or a relative of an employee in the district administrative offices. A parent representative shall not be a local board member or a board member's spouse. None of the members shall have a conflict of interest pursuant to KRS Chapter 45A, except the salary paid to district employees;

(b) 1. The teacher representatives shall be elected for one (1) year terms by a majority of the teachers. A teacher elected to a school council shall not be involuntarily transferred during his or her term of office. The parent representatives shall be elected for one (1) year terms. The parent members shall be elected by the parents of students preregistered to attend the school during the term of office in an election conducted by the parent and teacher organization of the school or, if none exists, the largest organization of parents formed for this purpose. A school council, once elected, may adopt a policy setting different terms of office for parent and teacher members subsequently elected. The principal shall be the chair of the school council.

2. School councils in schools having eight percent $(8 \%)$ or more minority students enrolled, as determined by the enrollment on the preceding October 1 , shall have at least one (1) minority member. If the council formed under paragraph (a) of this subsection does not 
have a minority member, the principal, in a timely manner, shall be responsible for carrying out the following:

a. Organizing a special election to elect an additional member. The principal shall call for nominations and shall notify the parents of the students of the date, time, and location of the election to elect a minority parent to the council by ballot; and

b. Allowing the teachers in the building to select one (1) minority teacher to serve as a teacher member on the council. If there are no minority teachers who are members of the faculty, an additional teacher member shall be elected by a majority of all teachers. Term limitations shall not apply for a minority teacher member who is the only minority on faculty;

(c) 1. The school council shall have the responsibility to set school policy consistent with district board policy which shall provide an environment to enhance the students' achievement and help the school meet the goals established by KRS 158.645 and 158.6451 . The principal shall be the primary administrator and the instructional leader of the school, and with the assistance of the total school staff shall administer the policies established by the school council and the local board.

2. If a school council establishes committees, it shall adopt a policy to facilitate the participation of interested persons, including, but not limited to, classified employees and parents. The policy shall include 
the number of committees, their jurisdiction, composition, and the process for membership selection;

(d) The school council and each of its committees shall determine the frequency of and agenda for their meetings. Matters relating to formation of school councils that are not provided for by this section shall be addressed by local board policy;

(e) The meetings of the school council shall be open to the public and all interested persons may attend. However, the exceptions to open meetings provided in KRS 61.810 shall apply;

(f) After receiving notification of the funds available for the school from the local board, the school council shall determine, within the parameters of the total available funds, the number of persons to be employed in each job classification at the school. The council may make personnel decisions on vacancies occurring after the school council is formed but shall not have the authority to recommend transfers or dismissals;

(g) The school council shall determine which textbooks, instructional materials, and student support services shall be provided in the school. Subject to available resources, the local board shall allocate an appropriation to each school that is adequate to meet the school's needs related to instructional materials and school-based student support services, as determined by the school council. The school council shall consult with the school media librarian on the maintenance of the school library media center, including the purchase of instructional materials, 
information technology, and equipment;

(h) Personnel decisions at the school level shall be as follows:

1. From a list of applicants submitted by the local superintendent, the principal at the participating school shall select personnel to fill vacancies, after consultation with the school council, consistent with subsection (2)(i)10. of this section. The superintendent may forward to the school council the names of qualified applicants who have pending certification from the Education Professional Standards Board based on recent completion of preparation requirements, outof-state preparation, or alternative routes to certification pursuant to KRS 161.028 and 161.048. Requests for transfer shall conform to any employer-employee bargained contract which is in effect.

2. If the vacancy to be filled is the position of principal, the school council shall select the new principal from among those persons recommended by the local superintendent, except as provided in subparagraph 4. of this paragraph. The superintendent shall provide additional applicants upon request when qualified applicants are available. The school council shall receive training in recruitment and interviewing techniques prior to carrying out the process of selecting a principal. The council shall select the trainer to deliver the training.

3. Personnel decisions made at the school level under the authority of subparagraphs 1., 2., and 4. of this paragraph shall be binding on the 
superintendent who completes the hiring process.

4. If the vacancy for the position of principal occurs in a school that has an index score that places it in the lowest one-third (1/3) of all schools below the assistance line and the school has completed a scholastic audit under KRS 158.6455 that includes findings of lack of effectiveness of the principal and school council, the superintendent shall appoint the principal after consulting with the school council.

5. Applicants subsequently employed shall provide evidence that they are certified prior to assuming the duties of a position in accordance with KRS 161.020. The superintendent shall provide additional applicants upon request when qualified applicants are available;

(i) The school council shall adopt a policy to be implemented by the principal in the following additional areas:

1. Determination of curriculum, including needs assessment, curriculum development and responsibilities under KRS 158.6453(7);

2. Assignment of all instructional and noninstructional staff time;

3. Assignment of students to classes and programs within the school;

4. Determination of the schedule of the school day and week, subject to the beginning and ending times of the school day and school calendar year as established by the local board;

5. Determination of use of school space during the school day; 
6. Planning and resolution of issues regarding instructional practices;

7. Selection and implementation of discipline and classroom management techniques as a part of a comprehensive school safety plan, including responsibilities of the student, parent, teacher, counselor, and principal;

8. Selection of extracurricular programs and determination of policies relating to student participation based on academic qualifications and attendance requirements, program evaluation, and supervision;

9. Procedures, consistent with local school board policy, for determining alignment with state standards, technology utilization, and program appraisal; and

10. Procedures to assist the council with consultation in the selection of personnel by the principal, including, but not limited to, meetings, timelines, interviews, review of written applications, and review of references. Procedures shall address situations in which members of the council are not available for consultation; and

(j) Each school council shall annually review data as shown on state and local student assessments and program assessments required under KRS 158.6453. The data shall include but not be limited to information on performance levels of all students tested, and information on the performance of students disaggregated by race, gender, disability, and participation in the federal free and reduced price lunch program. After completing the review of data, each school council, with the involvement 
of parents, faculty, and staff, shall develop and adopt a plan to ensure that each student makes progress toward meeting the goals set forth in KRS 158.645 and $158.6451(1)(b)$ by April 1 of each year and submit the plan to the superintendent and local board of education for review as described in KRS 160.340. The Kentucky Department of Education shall provide each school council the data needed to complete the review required by this paragraph no later than November 1 of each year. If a school does not have a council, the review shall be completed by the principal with the involvement of parents, faculty, and staff.

(3) The policies adopted by the local board to implement school-based decision making shall also address the following:

(a) School budget and administration, including: discretionary funds; activity and other school funds; funds for maintenance, supplies, and equipment; and procedures for authorizing reimbursement for training and other expenses;

(b) Assessment of individual student progress, including testing and reporting of student progress to students, parents, the school district, the community, and the state;

(c) School improvement plans, including the form and function of strategic planning and its relationship to district planning, as well as the school safety plan and requests for funding from the Center for School Safety under KRS 158.446;

(d) Professional development plans developed pursuant to KRS 156.095;

(e) Parent, citizen, and community participation including the relationship of 
the council with other groups;

(f) Cooperation and collaboration within the district, with other districts, and with other public and private agencies;

(g) Requirements for waiver of district policies;

(h) Requirements for record keeping by the school council; and

(i) A process for appealing a decision made by a school council.

(4) In addition to the authority granted to the school council in this section, the local board may grant to the school council any other authority permitted by law. The board shall make available liability insurance coverage for the protection of all members of the school council from liability arising in the course of pursuing their duties as members of the council.

(5) After July 13,1990, any school in which two-thirds (2/3) of the faculty vote to implement school-based decision making shall do so. All schools shall implement school-based decision making by July 1, 1996, in accordance with this section and with the policy adopted by the local board pursuant to this section. Upon favorable vote of a majority of the faculty at the school and a majority of at least twenty-five (25) voting parents of students enrolled in the school, a school meeting its goal as determined by the Department of Education pursuant to KRS 158.6455 may apply to the Kentucky Board of Education for exemption from the requirement to implement school-based decision making, and the state board shall grant the exemption. The voting by the parents on the matter of exemption from implementing school-based decision making shall be in an election conducted by the parent and teacher organization of the school or, if none exists, the largest 
organization of parents formed for this purpose. Notwithstanding the provisions of this section, a local school district shall not be required to implement schoolbased decision making if the local school district contains only one (1) school.

(6) The Department of Education shall provide professional development activities to assist schools in implementing school-based decision making. School council members elected for the first time shall complete a minimum of six (6) clock hours of training in the process of school-based decision making, no later than thirty (30) days after the beginning of the service year for which they are elected to serve. School council members who have served on a school council at least one (1) year shall complete a minimum of three (3) clock hours of training in the process of school-based decision making no later than one hundred twenty (120) days after the beginning of the service year for which they are elected to serve. Experienced members may participate in the training for new members to fulfill their training requirement. School council training required under this subsection shall be conducted by trainers endorsed by the Department of Education. By November 1 of each year, the principal through the local superintendent shall forward to the Department of Education the names and addresses of each council member and verify that the required training has been completed. School council members elected to fill a vacancy shall complete the applicable training within thirty (30) days of their election.

(7) A school that chooses to have school-based decision making but would like to be exempt from the administrative structure set forth by this section may develop a model for implementing school-based decision making, including but not limited 
to a description of the membership, organization, duties, and responsibilities of a school council. The school shall submit the model through the local board of education to the commissioner of education and the Kentucky Board of Education, which shall have final authority for approval. The application for approval of the model shall show evidence that it has been developed by representatives of the parents, students, certified personnel, and the administrators of the school and that two-thirds (2/3) of the faculty have agreed to the model.

(8) The Kentucky Board of Education, upon recommendation of the commissioner of education, shall adopt by administrative regulation a formula by which school district funds shall be allocated to each school council. Included in the school council formula shall be an allocation for professional development that is at least sixty-five percent (65\%) of the district's per pupil state allocation for professional development for each student in average daily attendance in the school. The school council shall plan professional development in compliance with requirements specified in KRS 156.095, except as provided in KRS 158.649. School councils of small schools shall be encouraged to work with other school councils to maximize professional development opportunities.

(9) (a) No board member, superintendent of schools, district employee, or member of a school council shall intentionally engage in a pattern of practice which is detrimental to the successful implementation of or circumvents the intent of school-based decision making to allow the professional staff members of a school and parents to be involved in the decision making process in working toward meeting the educational goals established in KRS 158.645 and 
158.6451 or to make decisions in areas of policy assigned to a school council pursuant to paragraph (i) of subsection (2) of this section.

(b) An affected party who believes a violation of this subsection has occurred may file a written complaint with the Office of Education Accountability. The office shall investigate the complaint and resolve the conflict, if possible, or forward the matter to the Kentucky Board of Education.

(c) The Kentucky Board of Education shall conduct a hearing in accordance with KRS Chapter 13B for complaints referred by the Office of Education Accountability.

(d) If the state board determines a violation has occurred, the party shall be subject to reprimand. A second violation of this subsection may be grounds for removing a superintendent, a member of a school council, or school board member from office or grounds for dismissal of an employee for misconduct in office or willful neglect of duty.

(10) Notwithstanding subsections (1) to (9) of this section, a school's right to establish or maintain a school-based decision making council and the powers, duties, and authority granted to a school council may be rescinded or the school council's role may be advisory if the commissioner of education or the Kentucky Board of Education takes action under KRS 160.346.

(11) Each school council of a school containing grades K-5 or any combination thereof, or if there is no school council, the principal, shall develop and implement a wellness policy that includes moderate to vigorous physical activity each day and encourages healthy choices among students. The policy may permit 
physical activity to be considered part of the instructional day, not to exceed thirty (30) minutes per day, or one hundred and fifty (150) minutes per week. Each school council, or if there is no school council, the principal, shall adopt an assessment tool to determine each child's level of physical activity on an annual basis. The council or principal may utilize an existing assessment program. The Kentucky Department of Education shall make available a list of available resources to carry out the provisions of this subsection. The department shall report to the Legislative Research Commission no later than November 1 of each year on how the schools are providing physical activity under this subsection and on the types of physical activity being provided. The policy developed by the school council or principal shall comply with provisions required by federal law, state law, or local board policy.

Effective: March 25, 2009

History: Amended 2009 Ky. Acts ch. 101, sec. 12, effective March 25, 2009. -- Amended 2008 Ky. Acts ch. 105, sec. 1, effective July 15, 2008. -- Amended $2005 \mathrm{Ky}$. Acts ch. 84, sec. 6, effective June 20, 2005. -- Amended 2004 Ky. Acts ch. 188, sec. 4, effective July 13, 2004. -- Amended 2003 Ky. Acts ch. 81, sec. 1, effective June 24, 2003. -- Amended $2002 \mathrm{Ky}$. Acts ch. 152 , sec. 1 , effective July 15 , 2002; and ch. 302, sec. 5, effective July 15, 2002. -- Amended 2000 Ky. Acts ch. 212 , sec. 1 , effective July 14, 2000; ch. 339 , sec. 2 , effective July 14,2000 ; ch. 418 , sec. 1 , effective July 14 , 2000; and ch. 527, sec. 14, effective July 14, 2000. -- Amended 1998 Ky. Acts ch. 
493, sec. 14, effective April 10, 1998; and ch. 609, sec. 3, effective July 15, 1998. -- Amended 1996 Ky. Acts ch. 34, sec. 1, effective July 15,1996 ; ch. 74 , sec. 1 , effective July 15,1996 ; ch. 146, sec. 1 , effective July 15,1996 ; ch. 318 , sec. 52 , effective July 15 , 1996; and ch. 362, secs. 1 and 6, effective July 15, 1996. -- Amended 1994 Ky. Acts ch. 103, sec. 3, effective July 15, 1994; ch. 187, sec. 1, effective July 15,1994 ; ch. 247 , sec. 1 , effective July 15,1994 ; ch. 411 , sec. 1 , effective July 15, 1994; and ch. 484 , sec. 1, effective July 15, 1994. -Amended 1992 Ky. Acts ch. 376, sec. 3, effective July 14, 1992; and ch. 393, sec. 3, July 14, 1992. -- Created 1990 Ky. Acts ch. 476, Pt. I, sec. 14, effective July 13, 1990.

Legislative Research Commission Note (7/15/96). This section was amended by $1996 \mathrm{Ky}$. Acts chs. 34, 74, 146, 318, and 362. Where these Acts are not in conflict, they have been codified together. A conflict exists between Acts chs. 34 and 362. Under KRS 446.250, Acts ch. 362, which was last enacted by the General Assembly, prevails.

2008-2010 Budget Reference. See State/Executive Branch Budget, 2008 Ky. Acts ch. 127, Pt. I, D, 3, (7) at 503; and State/Executive Branch Budget Memorandum, $2008 \mathrm{Ky}$. Acts ch. 188, at 1346 and 1352 (Final Budget Memorandum, Vol. III, at D-21, and D-23). 
Appendix B

Pre-Notice Letter

TO: $\quad$ SBDM COUNCIL CHAIRPERSONS

FROM: $\quad$ MARCO MUNOZ, ED.D.

SHAWNA STENTON

SUBJECT: SCHOOL BASED DECISION MAKING (SBDM) SURVEY

DATE: $\quad$ FEBRUARY 24, 2010

Soon you will be receiving a packet containing the School Based Decision Making (SBDM) survey for the 2009-2010 school year. We ask that you distribute this to your Council, and take just a few minutes to complete the survey. Make sure to add this as an agenda item for the next scheduled SBDM meeting. At the meeting each council member can complete the survey, and then surveys can be collected and returned to the SBDM Office no later than Friday, April 2, 2010. Please return surveys in the envelope provided in the packet.

We have streamlined our survey, and it should only take a few minutes to complete. Your response to the survey will be most helpful. It is only with the generous help of people like you that our research can be successful. The information gathered from this survey helps us determine how we can better support SBDM councils. We look forward to hearing from you. 
Appendix C

Survey Instructions

February 26, 2010

Dear SBDM Council Chairperson,

Enclosed are the School Based Decision Making (SBDM) surveys for the 2009-2010 school year. We ask that you distribute this to your council and take just a few minutes to complete the survey. Make sure to add this as an agenda item for the next scheduled SBDM meeting. At the meeting each council member can complete the survey with a $\# 2$ pencil, and then surveys can be collected and returned to the SBDM Office. Surveys must not be folded, stapled or bent. Please return surveys in the envelope provided in the packet no later than Friday, April 2, 2010.

We have streamlined this year's survey, and it should only take about 10 minutes of your time. Your response to the survey will be most helpful. It is only with the generous help of people like you that our research can be successful. The information gathered from this survey helps us determine how we can better support SBDM councils. We look forward to hearing from you. If you need additional copies or have any questions, please feel free to call me at 485-3056.

Many Thanks,

Shawna L. Stenton

SBDM Specialist 
Appendix D

Survey Instrument

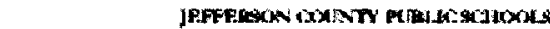

(1)

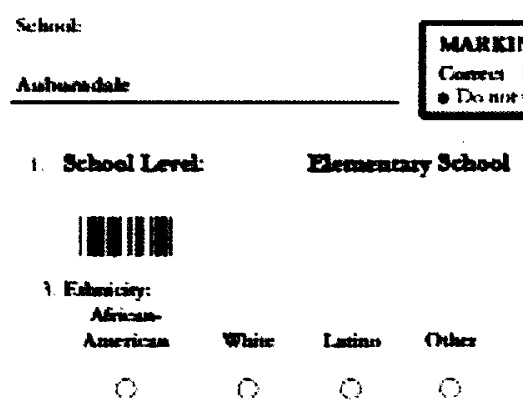

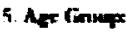

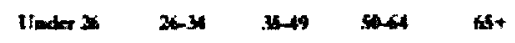

i 00000

7. Yran we the Cinmart

Lom ine it it it

i $0 \quad 0$

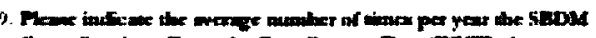

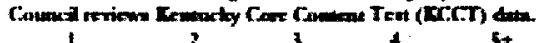

a $\% \quad 0 \quad 0$

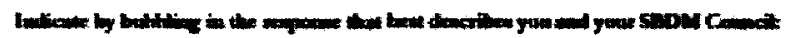

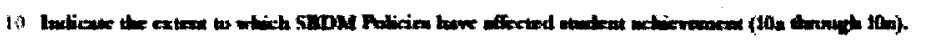

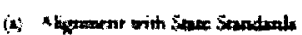
(h) rominime

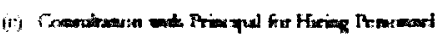
(i) Turixiken

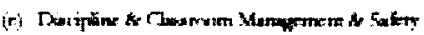
(f) Frisenring Simulent wheremrom

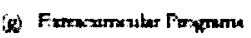

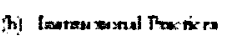

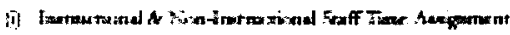
5) Toxprum Mrosial

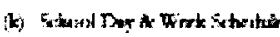
(1) 5xisulase lin

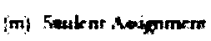
(n) Totual betio

Nom

$\begin{array}{ll}0 & 6 \\ 0 & 0 \\ 0 & 0 \\ 0 & 0 \\ 0 & 0 \\ 0 & 0 \\ 0 & 0 \\ 0 & 0\end{array}$

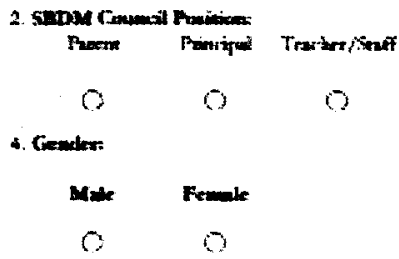

Lax t: $\quad$ in

fi. Lewed of Fin:minax

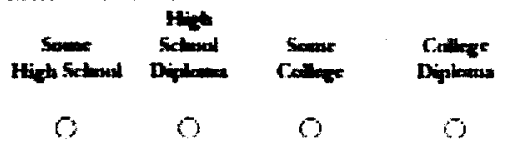

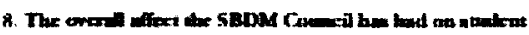
whionsmen

\begin{tabular}{|c|c|c|c|}
\hline$N=$ & $\operatorname{Lan}$ & Avarace & Hiveh \\
\hline 2 & $\sigma$ & 5 & $\mathrm{~b}$ \\
\hline
\end{tabular}




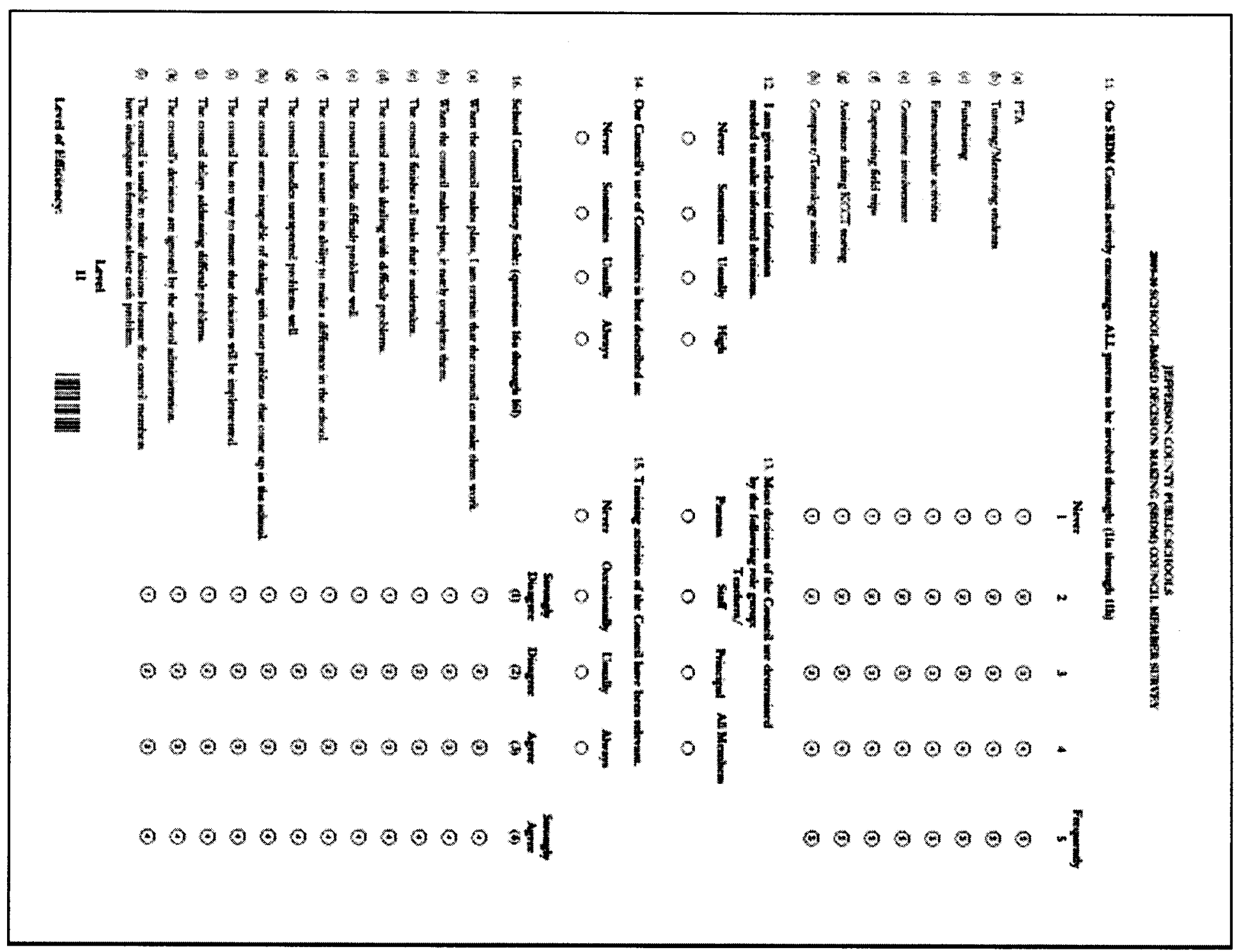


Appendix E

Reminder Letter

TO:

SBDM COUNCIL CHAIRPERSONS

FROM: $\quad$ MARCO MUNOZ, ED.D.

SHAWNA STENTON

SUBJECT: SCHOOL BASED DECISION MAKING (SBDM) SURVEY

DATE: $\quad$ MARCH 15, 2010

You should have already received the School Based Decision Making (SBDM) surveys for the 2009-2010 school year. We remind you to distribute this to your council and take just a few minutes to complete the survey. Make sure to add this as an agenda item for the next scheduled SBDM meeting. At the meeting each council member can complete the survey with a \#2 pencil, and then surveys can be collected and returned to the SBDM Office. Surveys must not be folded, stapled or bent. Please return surveys in the envelope provided in the packet no later than Friday, April 2, 2010.

If you have not already received these surveys, please contact Shawna Stenton at 3056.

We have streamlined this year's survey, and it should only take a few minutes of your time. Your response to the survey will be most helpful. It is only with the generous help of people like you that our research can be successful. The information gathered from this survey helps us determine how we can better support SBDM councils. We look forward to hearing from you. 


\begin{abstract}
Appendix F
Regression Summary for Dependent Variable Efficacy and 11 Predictors, With Ethnicity Defined as White or Minority

Table F-1 shows descriptive statistics on the regression analysis of efficacy predicted by 11 variables. In this analysis, the variable ethnicity is defined as White or Minority. Minority included African-American, Asian, Hispanic, and Other. Table F-2 shows regression coefficients for predictor variables.

Regression Summary for Dependent Variable Productivity and 11 Predictors, With Ethnicity Defined as White or Minority

Table F-3 shows descriptive statistics on the regression analysis of Productivity predicted by 11 variables. In this analysis, the variable ethnicity is defined as White or Minority. Minority included African-American, Asian, Hispanic, and Other. Table F-4 shows regression coefficients for predictor variables.
\end{abstract}


Table F-1

Means, Standard Deviations, and Correlations for Regression with Dependent Variable Efficacy $(N=621)$.

Variable $M$

Variable $\begin{array}{lllllllll}M & S D & 1 & 2 & 3 & 4 & 5 & 6 & 7\end{array}$

Efficacy

$3.47 \quad .44$

1. Age

$2.99 \quad .78$

$-.01 \quad-.04$

$.04 \quad .00 \quad .02$

2. Years on council

$2.23 \quad 1.03 \quad-$

$.33 * * \quad .03$

.00

$.08^{*} \quad .01$

$.01 \quad .47 *$

3. Gender

4. Ethnicity ${ }^{\mathrm{a}}$

$.74 \quad .4$

$.24 \quad .43$

$-.03$

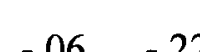

.22 . $\quad-.03$

\begin{tabular}{lllll}
\hline$* *$ & $.34^{* *}$ & $.34 * *$ & -.05 & $.08 *$
\end{tabular}

5. Contrast between parents

$$
\begin{array}{llllllllllllllllllll}
\text { and teachers } / \text { staff } & .28 & .45 & - & - & - & - & - & - & -.25 & .07 * & -.06 & -.05 & .03 & -.01
\end{array}
$$

6. Contrast between principals

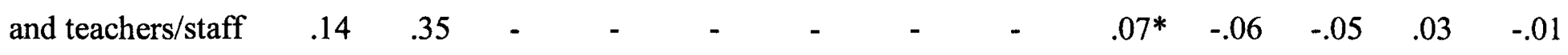

7. Relevant information

$3.72 \quad .51$

8. Use of committees

$3.24 \quad .79$

9. Training activities

$3.27 \quad .70$

10. School level

$1.64 \quad .81$

11. Level of efficiency

$2.78 \quad .88$

a Ethnicity defined: Minority $=1$, White $=0$.

${ }^{*} p<.05$

$* * p<.01$ 
Table F-2

Partial Coefficients for Regression with Dependent Variable Efficacy With Ethnicity

Defined Minority or Non-Minority $(N=621)$.

Variable

B

SEB

$\beta \quad \mathrm{sr}^{2}$

Constant

1.56

.15

.02

Age

.01

.02

.02

Years on council

$-.01$

.02

$-.03$

Gender

.00

.04

.00

Ethnicity

$-.02$

.04

$-.01$

D code position 1

.07

.04

$.07 *$

.00

D code position 2

.02

.05

.02

Relevant information

.31

.03

$.36 * *$

.11

Use of committees

.10

.02

$.19 * *$

.03

Training activities

.10

.03

$.16^{* *}$

.02

School level

$-.01$

.02

$-.01$

Level of efficiency

.02

.02

.04

$* p<.05 \quad * * p<.01$

Note. Gender was coded: female $=1$, male $=0 ;$ Ethnicity was coded: Minority $=1$, White $=0 . \mathrm{sr}^{2}$ are squared semipartial correlations for significant predictors. For this model: $\mathrm{R}^{2}=.296$ (adjusted $\mathrm{R}^{2}=.283$ ). 
Table F-3

Research question 4: Means, standard deviations, and correlations for minority and non-minority $(N=625)$.

\begin{tabular}{|c|c|c|c|c|c|c|c|c|c|c|c|c|c|}
\hline Variable & $\bar{M}$ & $S D$ & 1 & 2 & 3 & 4 & 5 & 6 & 7 & 8 & 9 & 10 & 11 \\
\hline Productivity & 3.48 & .47 & -.03 & .01 & .01 & .02 & $-.07 *$ & .02 & $.39 * *$ & $.33^{* *}$ & $.35 * *$ & $-.14 * *$ & $.17^{* *}$ \\
\hline 1. Age & 2.98 & .77 & - & $.33 * *$ & .04 & .00 & .06 & $.22 * *$ & -.04 & $-.09 *$ & -.01 & .05 & .01 \\
\hline 2. Years on council & 2.24 & 1.03 & - & - & .02 & $-.07 *$ & $-.22 * *$ & $.39 * *$ & .00 & -.02 & -.06 & -.03 & .02 \\
\hline 3. Gender & .74 & .44 & - & - & - & .04 & -.02 & -.04 & -.02 & -.03 & .06 & $-.34 * *$ & .09 \\
\hline 4. Ethnicity & .24 & .43 & - & - & - & - & -.06 & .03 & -.05 & $.10^{* *}$ & $.16^{* *}$ & -.05 & $.07^{*}$ \\
\hline \multicolumn{14}{|l|}{ 5. Contrast between parents } \\
\hline and teachers/staff & .28 & .45 & - & - & - & - & - & $-.25 * *$ & $.08^{*}$ & -.06 & -.05 & .03 & -.01 \\
\hline \multicolumn{14}{|c|}{ 6. Contrast between principals } \\
\hline and teachers/staff & .14 & .35 & - & - & - & - & - & - & .07 & -.04 & -.01 & $-.07^{*}$ & .06 \\
\hline 7. Relevant information & 3.72 & .50 & - & - & - & - & - & - & - & .27 & $.31 * *$ & -.03 & .04 \\
\hline 8. Use of committees & 3.24 & .79 & - & - & - & - & - & - & - & - & $.40 * *$ & $-.10^{* *}$ & $.09 *$ \\
\hline 9. Training activities & 3.27 & .70 & - & - & - & - & - & - & - & - & - & $-.07^{*}$ & $.08^{*}$ \\
\hline 10. School level & 1.63 & .81 & - & - & - & - & - & - & - & - & - & - & $-.15^{* *}$ \\
\hline 11. Level of Efficiency & 2.78 & .88 & - & - & - & - & - & - & - & - & - & - & - \\
\hline
\end{tabular}

$* P<.05 \quad * * P<.01$ 
F-4

Partial Coefficients for Regression with Dependent Variable Productivity, With Ethnicity Defined Minority or Non-Minority $(N=625)$.

$\begin{array}{lllll}\text { Variable } & \text { B } & \text { SEB } & \beta & \mathrm{sr}^{2}\end{array}$

Constant

Age

Years on council

Gender

Ethnicity

Contrast between parents
1.72

.01

.01

$-.04$

$-.03$

$-.08$

.04

$-.07$

Contrast between principals

and teachers/staff

$-.04$

.27

.09

.13

$-.06$

.07
.05

.04

.02

.03

.02

.02
.01

.01

$-.03$

$-.03$
School level

Level of efficiency
$-.03$

$.29 * *$

.07

$.15^{* *} \quad .02$

$.18^{* *} \quad .03$

$\begin{array}{ll}-.10 & .01\end{array}$

$.12^{* *} \quad .01$

Note. Gender was coded: female $=1$, male $=0 ;$ Ethnicity was coded: Minority $=1$,

White $=0 . \mathrm{sr}^{2}$ are squared semipartial correlations for significant predictors. For this model: $\mathrm{R}^{2}=.262$ (adjusted $\mathrm{R}^{2}=.249$ ).

${ }^{*} p<.05 \quad * * p<$ 


\section{CURRICULUM VITAE}

NAME: Shawna Shrout Stenton

ADDRESS: 7606 Norbourne Avenue

Louisville, Kentucky 40222

DOB: $\quad$ Louisville, Kentucky - July 10, 1976

\section{EDUCATION}

\& TRAINING: B.A., English

Hanover College

1994-1998

M.A.T., Elementary Education

Bellarmine University

1999-2000

Rank I, Literacy

University of Louisville

2002-2004 


\author{
Ed.S., Administration \\ University of Louisville \\ 2005-2007 \\ Ph.D., Educational Administration \\ University of Louisville \\ 2005-10
}

\begin{abstract}
AWARDS: Ignite Louisville Participant
2010

Who's Who Among Executives and Professionals

2010
\end{abstract}

Scottish Rite Fellowship

2009-10

Wilma Berlin Member's Scholarship

2009

Service Learning grant recipient

2009

Inspiration for student essay that won $1^{\text {st }}$ place in the Kentucky Association of School Administrators contest

2008 
Recipient of the Classroom Performance System

2008

Who's Who Among America's Teachers

2006

Louisville Writing Project Fellow

2004-05

Norton Grant to attend the Waldorf Approach in the Public Classroom Institute in Sacramento, California

2004

\section{PROFESSIONAL}

SOCIETIES: $\quad$ Leadership Louisville

2010-Present

KASC Certified Trainer

2009-Present

Executive Board Member

Scouting Unlimited

2009-Present

Kentucky Association of School Councils

2009-Present 
Jefferson County Association of School

Administrators

2009-Present

ASCD

2009-Present

Women in School Administration

2006-Present

National Education Association

2001-Present

Kentucky Education Association

2001-Present

Jefferson County Teachers Association

2001-2009

PRESENTATIONS: “The Principal's Role in the Principal Selection Process"

Various elementary, middle, and high schools throughout JCPS

Ongoing as needed

"Introduction to SBDM Part I and II"

JCPS Gheens Academy

Ongoing 
"Senate Bill 1 and Writing Policies"

JCPS VanHoose Education Center

Various times throughout spring 2010

"JCPS Schools"

Focus Louisville

February, 2010

"The New Principal's Role in SBDM"

Sullivan University

February, 2010

"Steps to Student Proficiency"

JCPS Gheens Academy

January, 2010

"Advanced Bylaws and Policies"

Fairdale High School

November, 2009

"SBDM Parental Involvement"

Parent Leadership Academy

October, 2009

"Parental Involvement in Schools"

Parent Leadership Academy

October, 2009 
"How to Get Involved in SBDM"

Lincoln Foundation, Spaulding University

September, 2009

"The PTA and SBDM"

JCPS Gheens Academy

September, 2009

"The Principalship and SBDM"

Bellarmine University

July, 2009

"Introduction to the Science Modules"

JCPS Gold Days

2006-07

"Introducing Plants in Early Primary"

JCPS Gheens Academy

July, 2003

"The Nuts and Bolts of Science Modules"

JCPS Gheens Academy

July, 2006 
"Science Modules in the Classroom"

Jeffersontown Elementary School

August, 2004

"Introduction to the Writer's Notebook"

University of Louisville

March, 2004

"Building a Classroom Community"

University of Louisville

October, 2003

"Animals 2x2"

JCPS Gheens Academy

July, 2003 